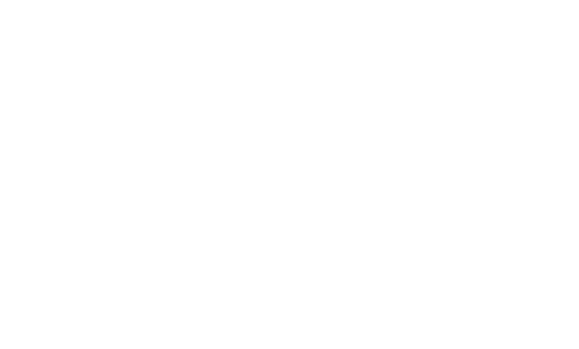

\title{
درلمة أعداط
}

\section{د. راثند بن مبارك المشتود}

الأستاذ المساعد في قسم اللغة العربية - كلية الآداب

جلمعة الملكسعود

الجول: 0507487268

البريد الإلكتروف: krushood@ ksu.edu.sa

مالخص البهث

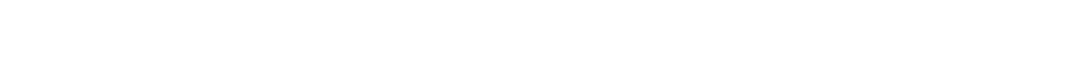

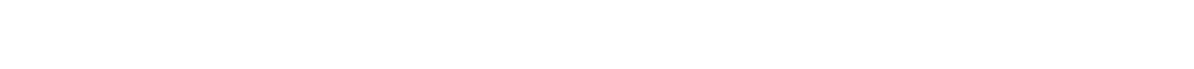
الإسلامية فيشعره من حيث مفهومه للألوهية والنبوة وغيرهما، ومن ثم منالة ششة الإنة

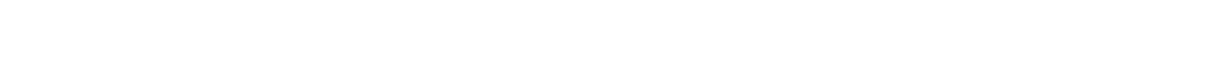

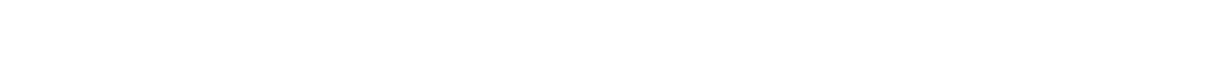
هذا البهث بالحيث عن أثر الإسلام في الصورة الفنية لديه. 


\section{بعم الـ الرحمن الرحيم}

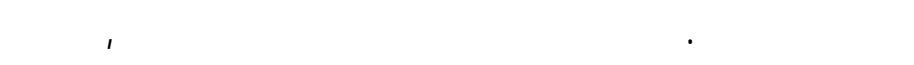

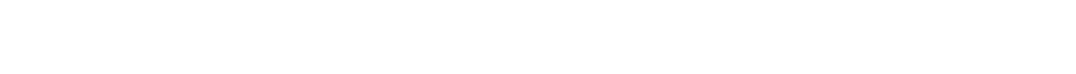

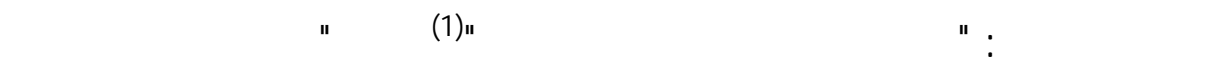

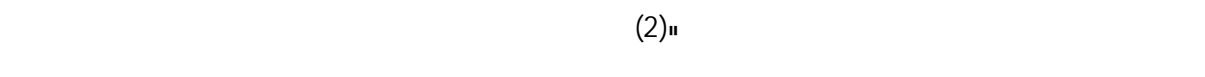

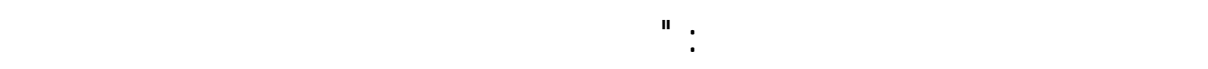
هو نيوانها" (3).

وللشعر في كل أمة خاضع لظ ـور حياته الف ف في الذ ـولجي الـ سيلسية والاجتماعية والقفافية والاقتصاية، وهي التي تحدد مجره وم ساربه والتجاهاتة هـ

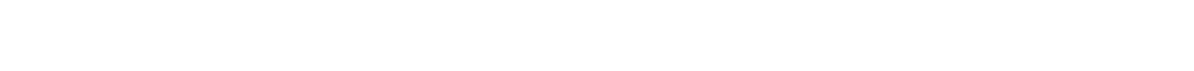

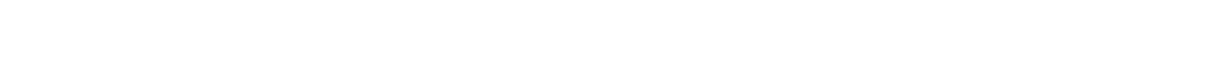

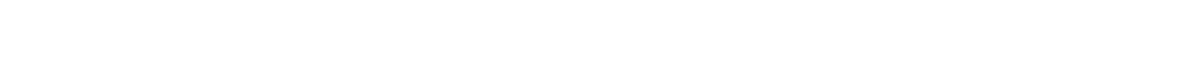

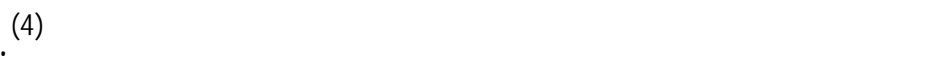

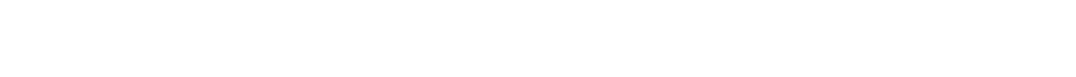

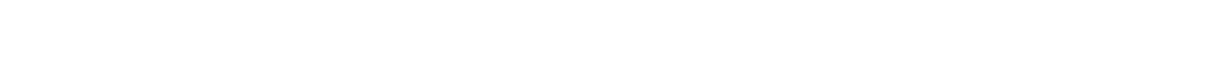

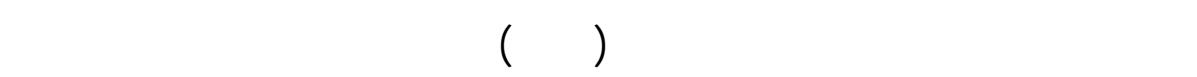
جعلت مقومات الحية الاجتماعية والخلقية عند الجاهليين تهتز اهتزالزا عنيفًا.

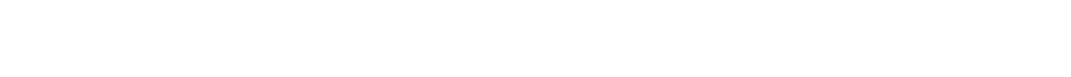

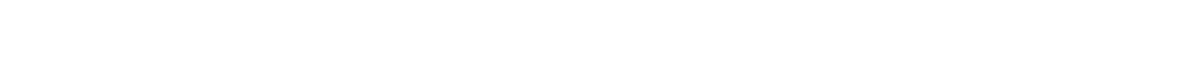

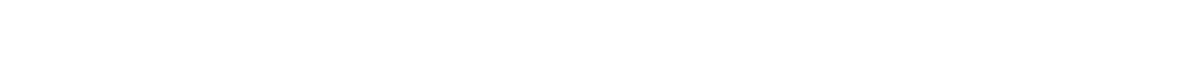
محور مدائحهُ، ومدار قصائدهم وشعرهم في الجاهلية يستوي في ذلك الـ شععراء

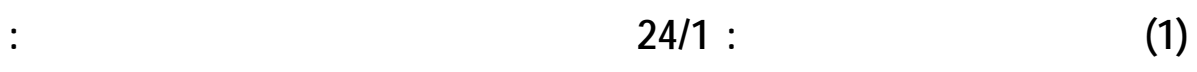


بشق عقائدهم الدينية للساقة للإبسلام.

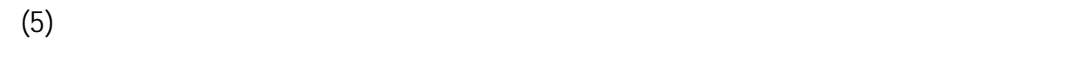
هو الأططل التغلبي، ودرلسة كف أثر الإسلام فيشعره .

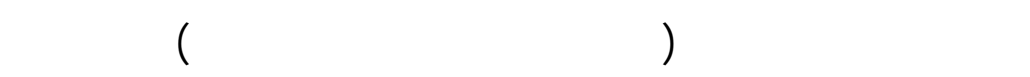

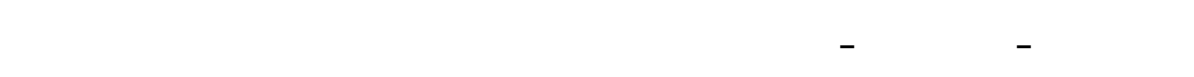

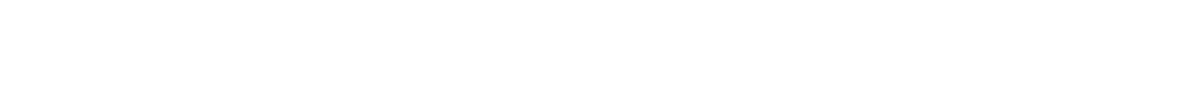

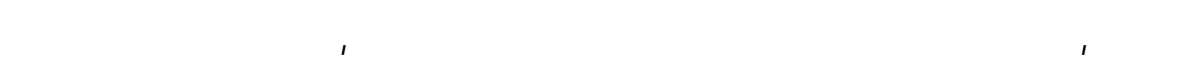

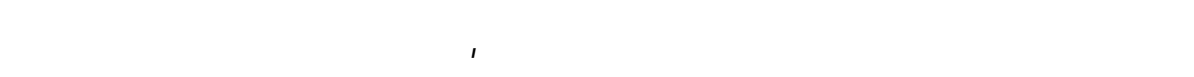

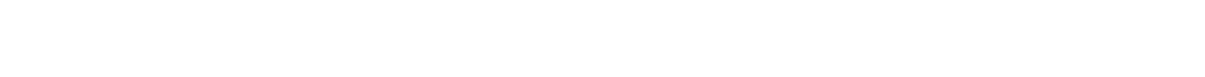

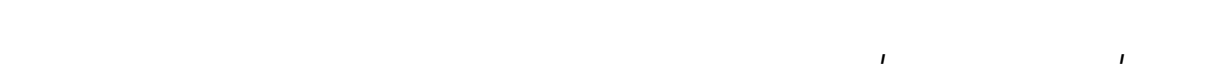

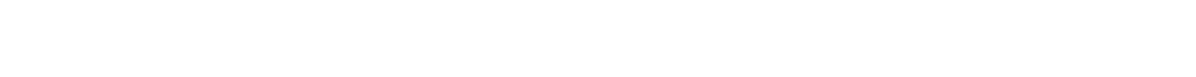
النصرالني الذي علث في العصر الأموي.

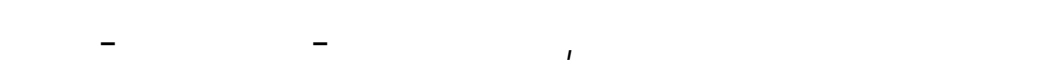

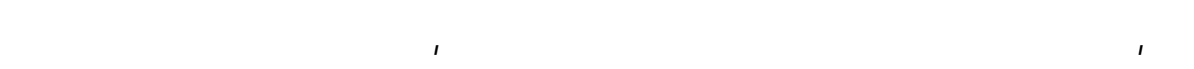

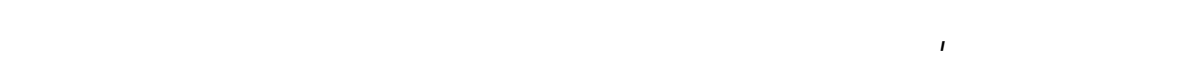

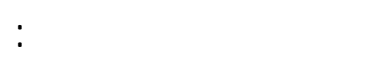
المبحث الأول: عنسيرة الأظطل وعلاقتها بالين .

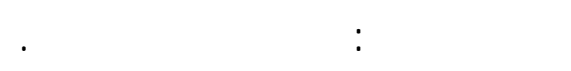

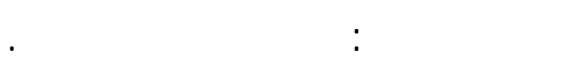
المبدث الراليع: عن العبادات الإبلامية المناية

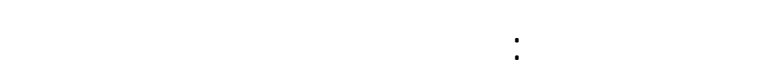

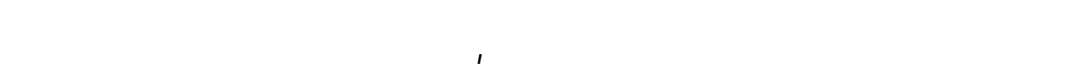
قلبك, وحنايا فؤاك, فقبلتها قبول الراضي المبتهج فهذا ما أردته وسعيت إليه, وإلا إلا

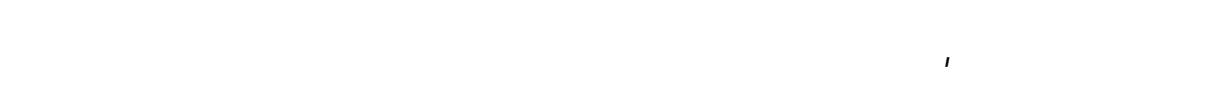

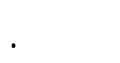


د/ راشد بن مبارك الرشود

\section{المبهث الأل وبال}

\section{سبيرة الأخل وعلافتها بالين}

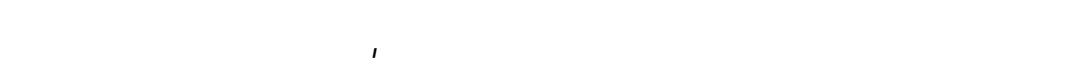

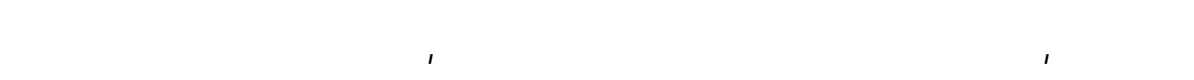

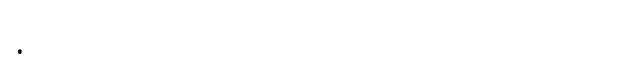

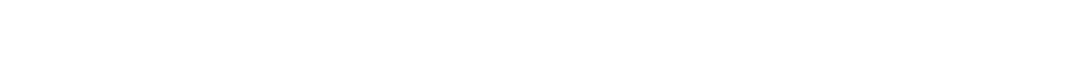

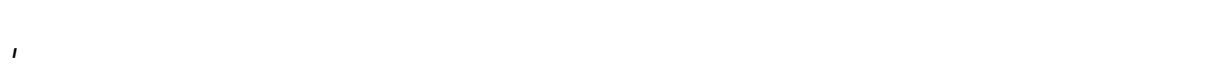

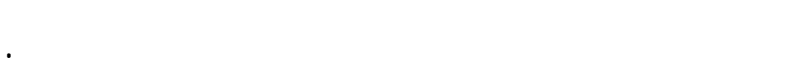

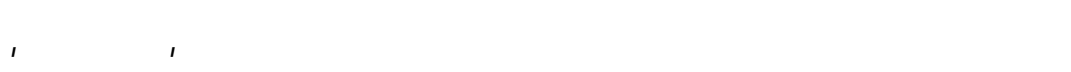

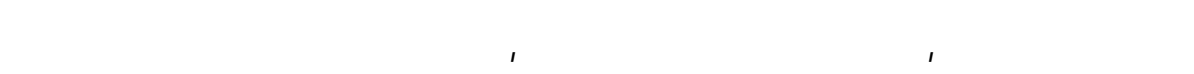

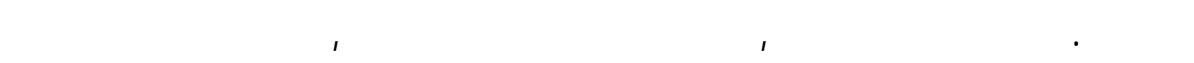

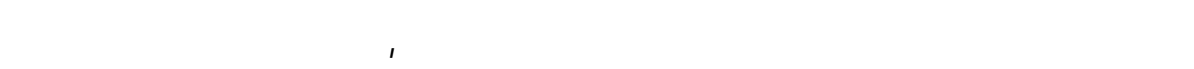
عجيبة, وعلاقلت متشابكة, وصلات حميمة, وانحرافلت عن الصرلطا للسوي .

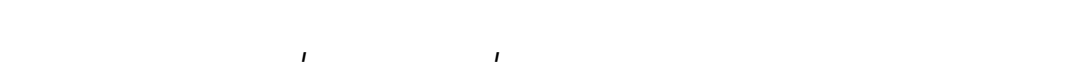

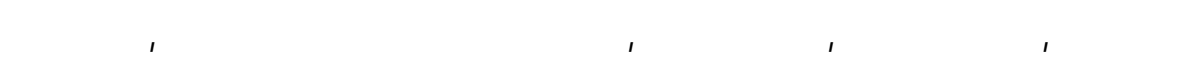

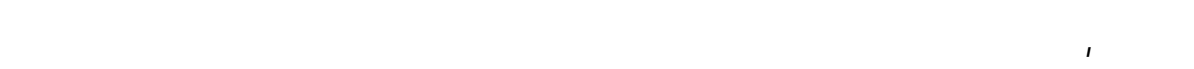

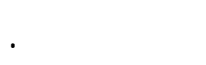
وهذا الذي حطل بالفعل, فقد لستظل الأخطل أول فرصةسنحت له لتحقيق

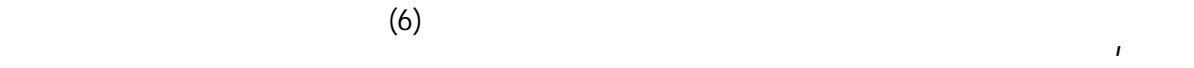
رهط الأخطل, فلكرموه, وأعطوه, ولكن هذا للشب لم يجار قومه في الإكرله, بـ جل جل

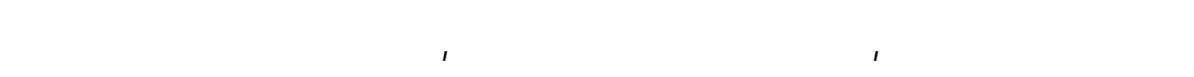

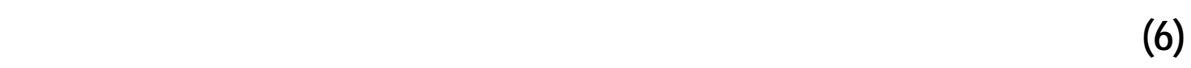

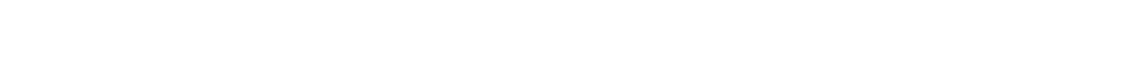

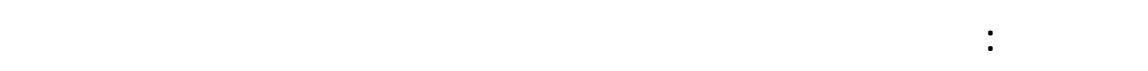

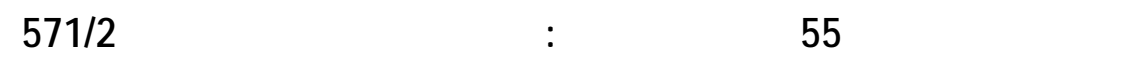

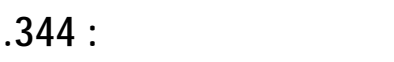




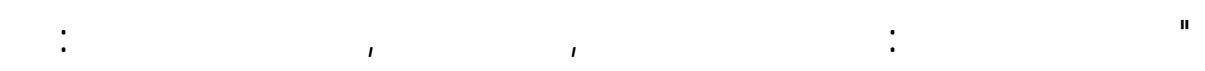
هجوتنا هجونك ... فقل كعب: ومن يهجوني؟ قل: أنا، فقل كعب:[الرجز]

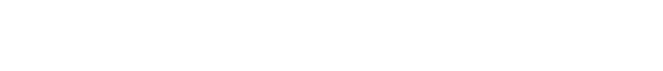

\section{فقل الأخطل: [الرجز]

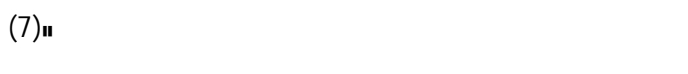

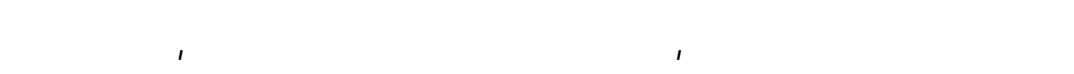

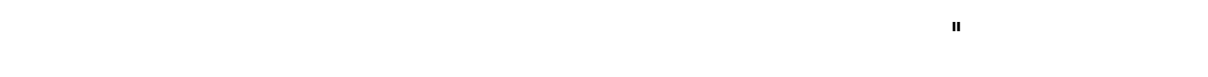

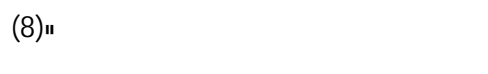
فهن هنا نرى أن الأخطلشقّطريقه نحو التأق الشعري, والمجد الأببي,

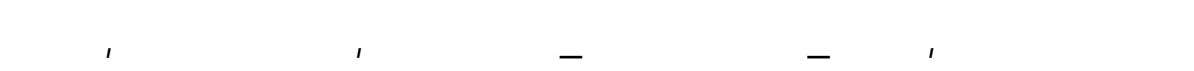

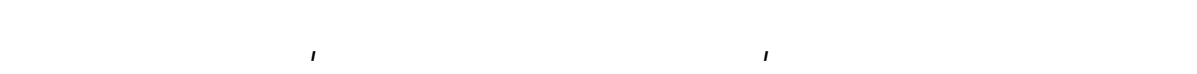
والتواريخ, ومعرفة بالمثالب والمناقب.

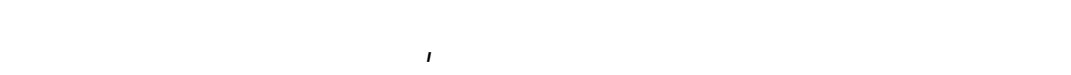

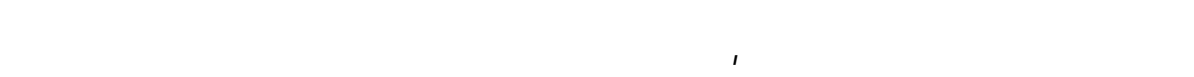

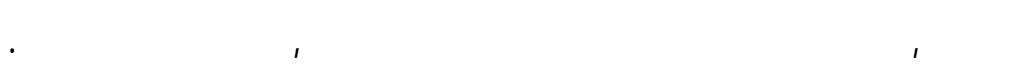

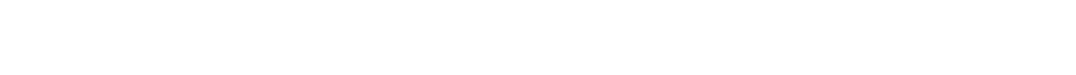

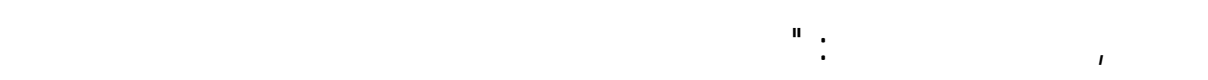

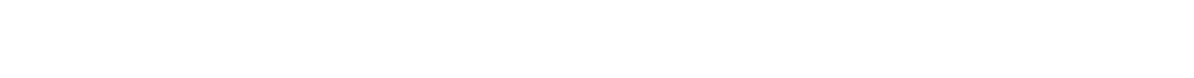

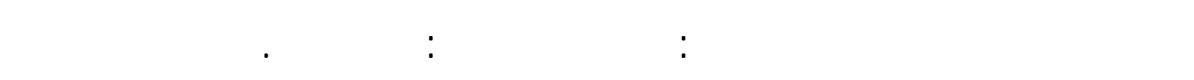

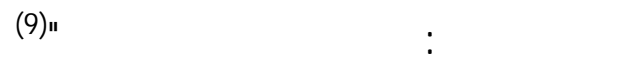

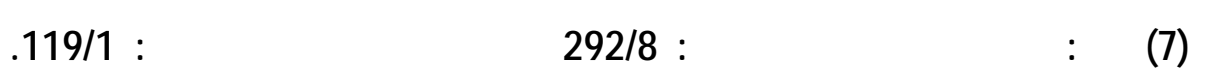
والبداي، خزلة الأهب: 1738/1.

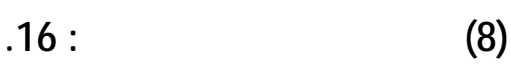
(9) للن بكلر، الأخبار الموقيلت: 194 -195. 
د/ داشند بن مبارك الرشود

فهجاهم الأنطل بأبياته المشهورة, التي منها قوله :[البسيط] (10)

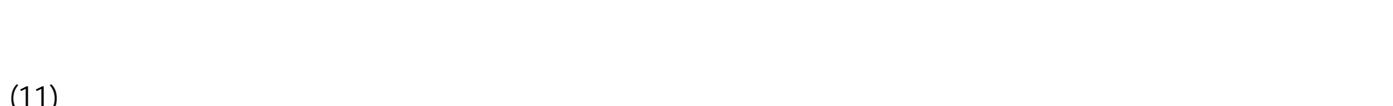

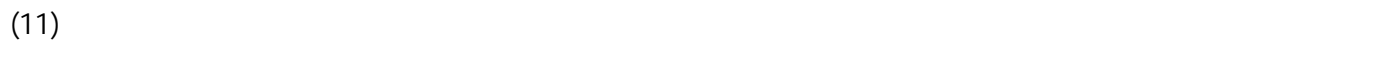

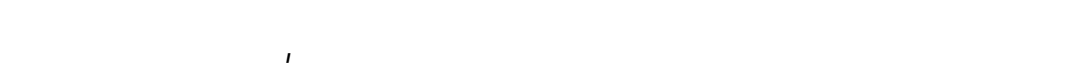

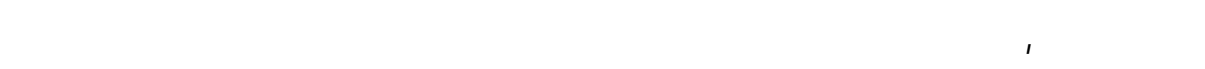

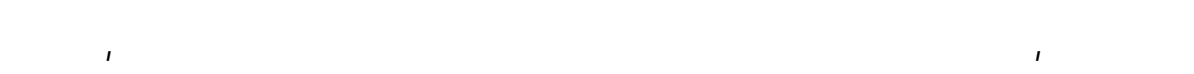

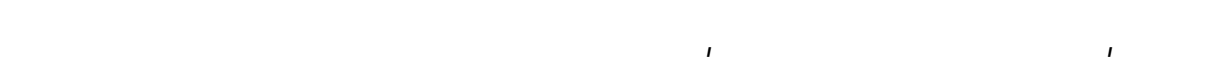

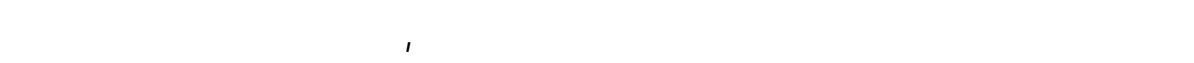

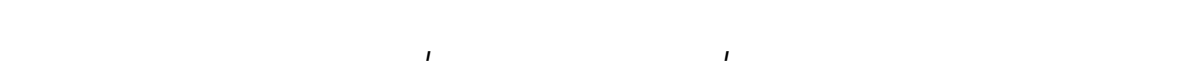

الأنصار (12)

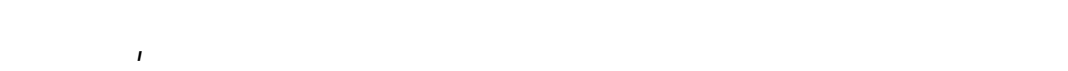

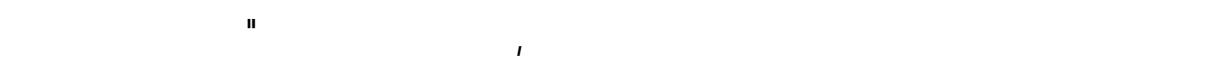

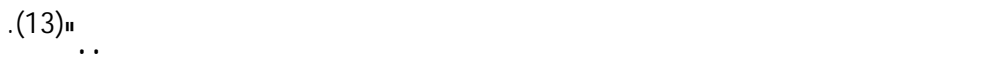

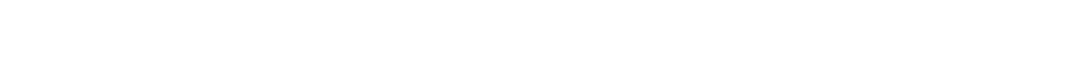

$$
\text { يزيد, حيث قل : [الطويل] (14) }
$$

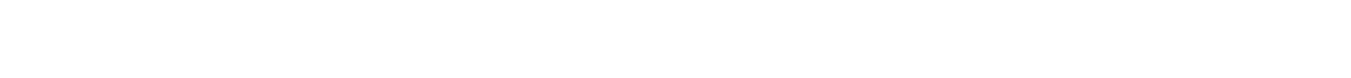

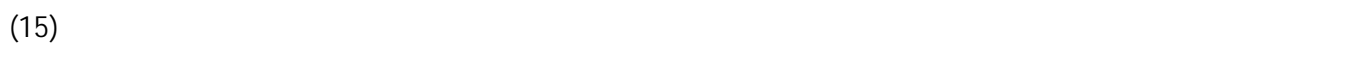

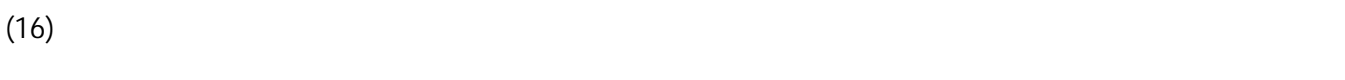

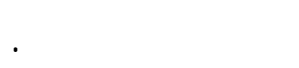

ولعلسبب البعد بينهما أن معاوية لحد صحابة لسول اله صلى اله علي هa

$$
\text { 484-483/2: (10) (11) }
$$

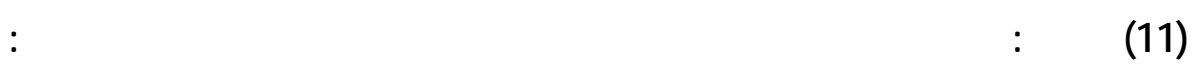

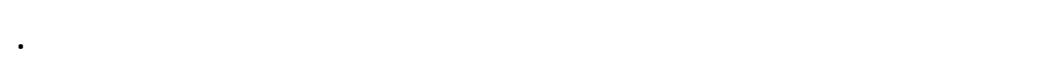

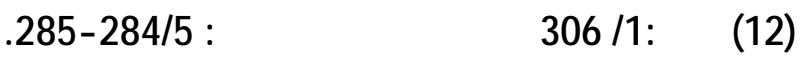

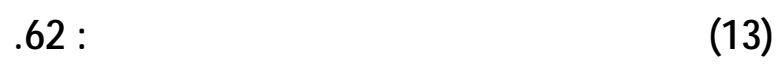

(15) (15) الديطن: (1308)

. $\square[: 08$ (15)

مجلة بحث كلية الآلب

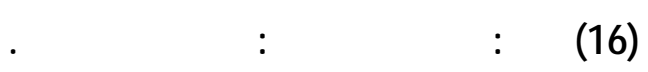


أثر الإسلام في شعر الأخل

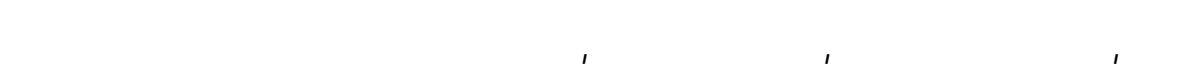

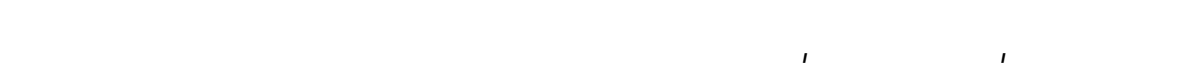

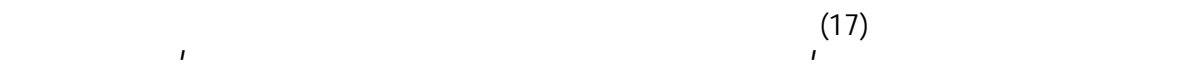

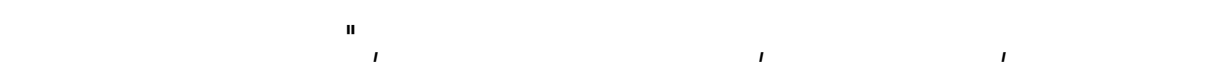

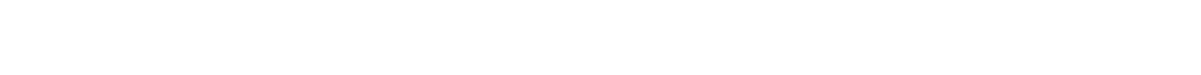
في عهد معاوية" (18)

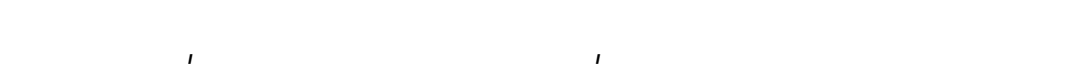

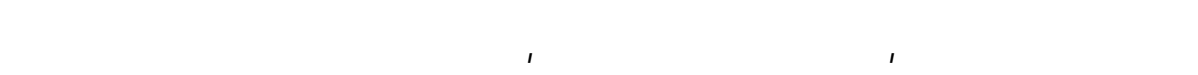

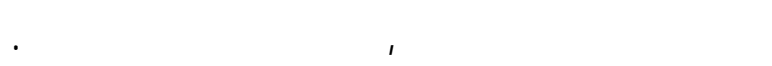

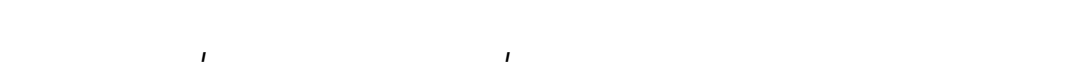

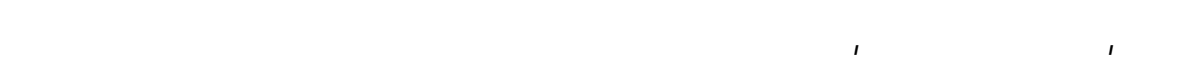

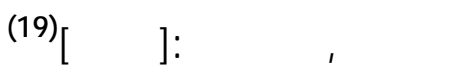

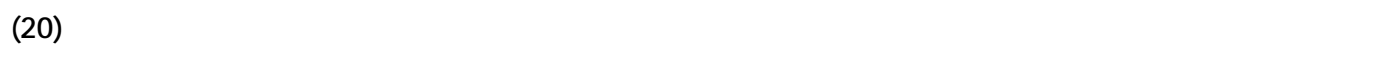

وفي كل منلسبة له يعيد نكر هذه الحاثة, وكف خلصه يزيد منش -ركها

حق قل فيه: [البسط][21) :

(22)

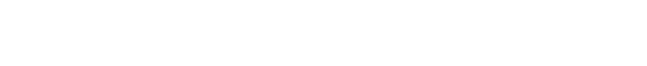
(23)

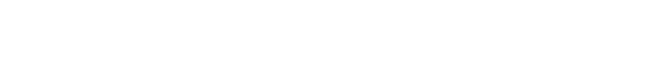

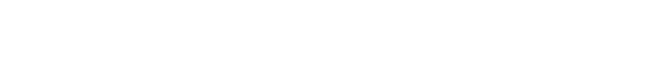

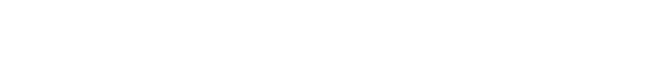

$$
\begin{aligned}
& \text { (17) المار،بلوة، الأغل الكبل: } 63 . \\
& \text { (18)قبلوة، الأفل الكبل: } 69 . \\
& \text { (19) (208/1) }
\end{aligned}
$$

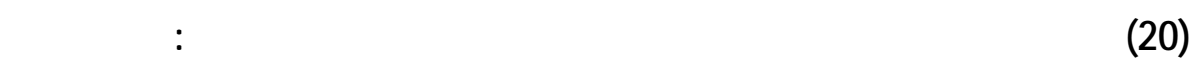

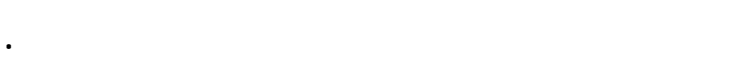

(21) نوله:

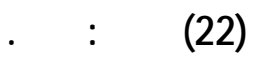

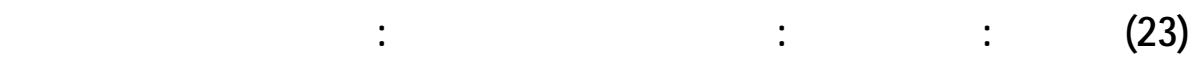

اللهم.

7

مجلة بحوث كلية الآدل 
د/ راشد بن مبارك الرشود

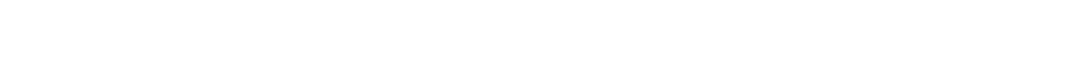
مواقف مع الأخطل_أقفه فيها منشر محقق, كما قل: [البسط] (24)

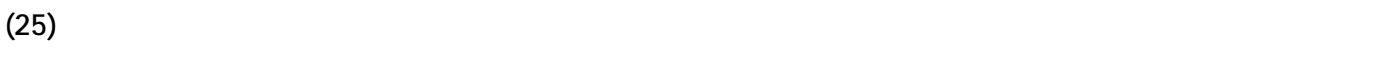
(26) 距 ويشي عليه في قصيدة لخرى, فيقول: [الطوي]] (27)

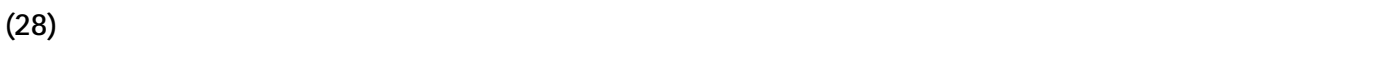
وفضل قريش في عمومها عليه أمر لا ينكره الأخطل بل يردده دالئها كلما

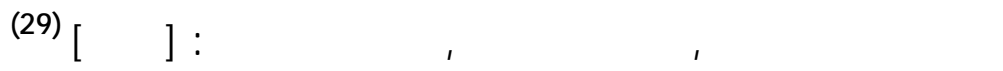

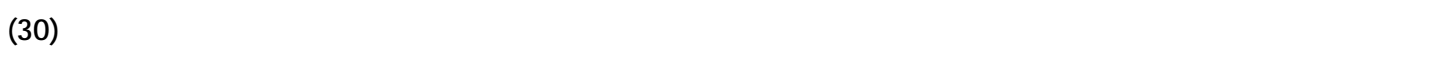

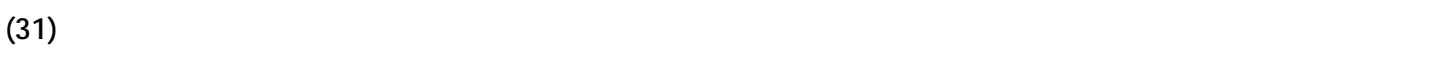
وقوله: [البسيط] (32)

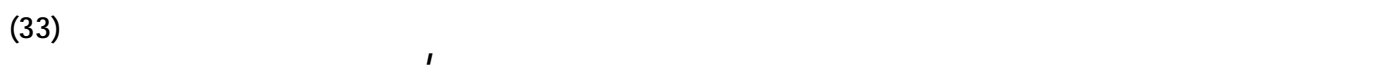
قوقوله: [الوافر]

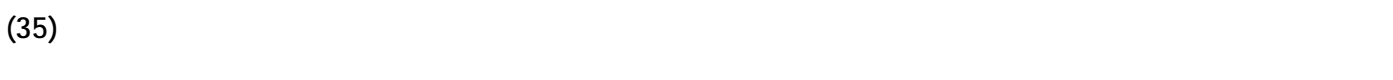
(222/1) يواله:

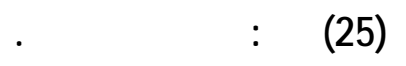

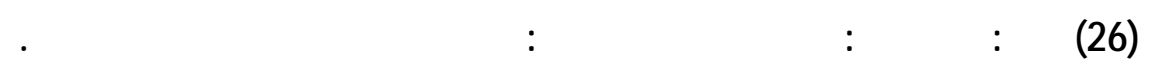
(28) (28/1) نوله:

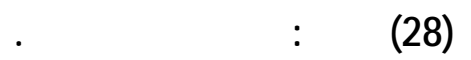
(29) ديوله: 171/1. (30) الركلت: الإل النجهة إلمكه.

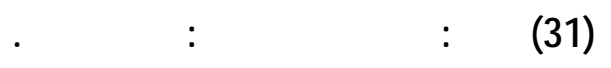
(32) نيوله: 172/1.

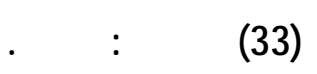

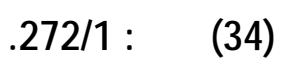
مجلة بحوث كلية الآدلب

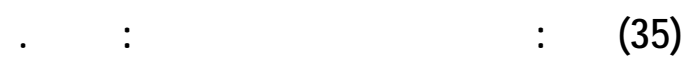




$$
\text { أثثر الإسلام في شعر الأخل }
$$

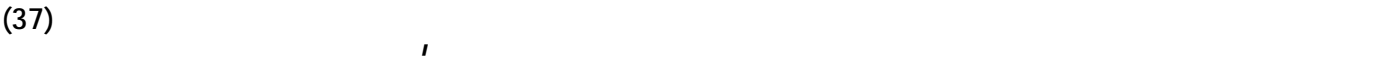

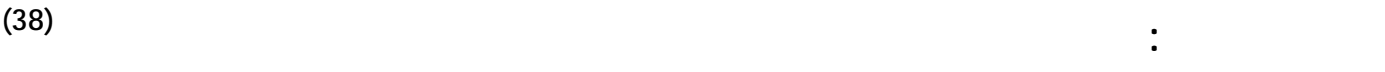

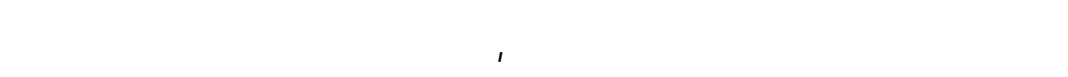

لصالحهر ميله وهول, وفداهم بأهله وفنسه, فها هو يقول: [الواور]]

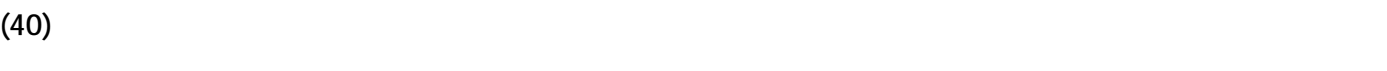

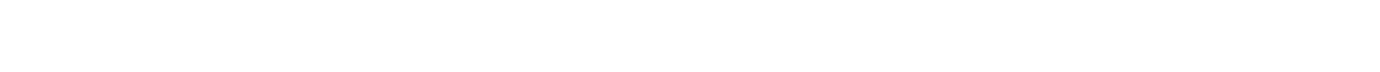

ويبلغ الإخلاص والفاني في خلمتهر منتهل حن يقول: [البسط] (41)

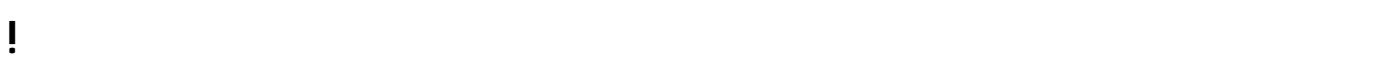

$$
\text { مفالته ولأظلفه }
$$

كان أبومالك كثير الفخر بفسه, وقبيلته تتغلب, التي حفل تاريخها الطويل,

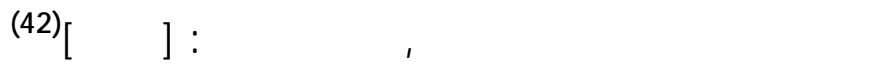

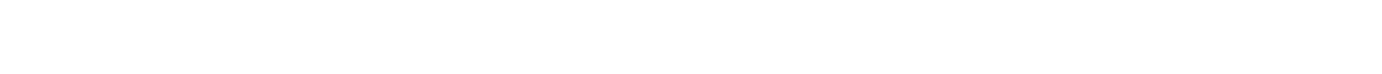

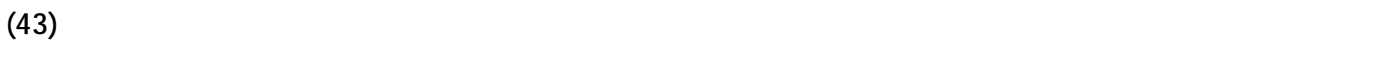

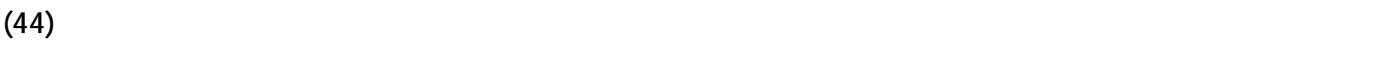
وإلى جانب مفلخره ومآثر قبيلته, فإنه قد علث فترات مـ ن الـ ـزمن ف مي

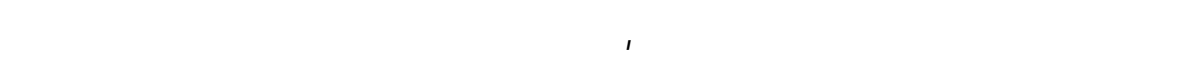

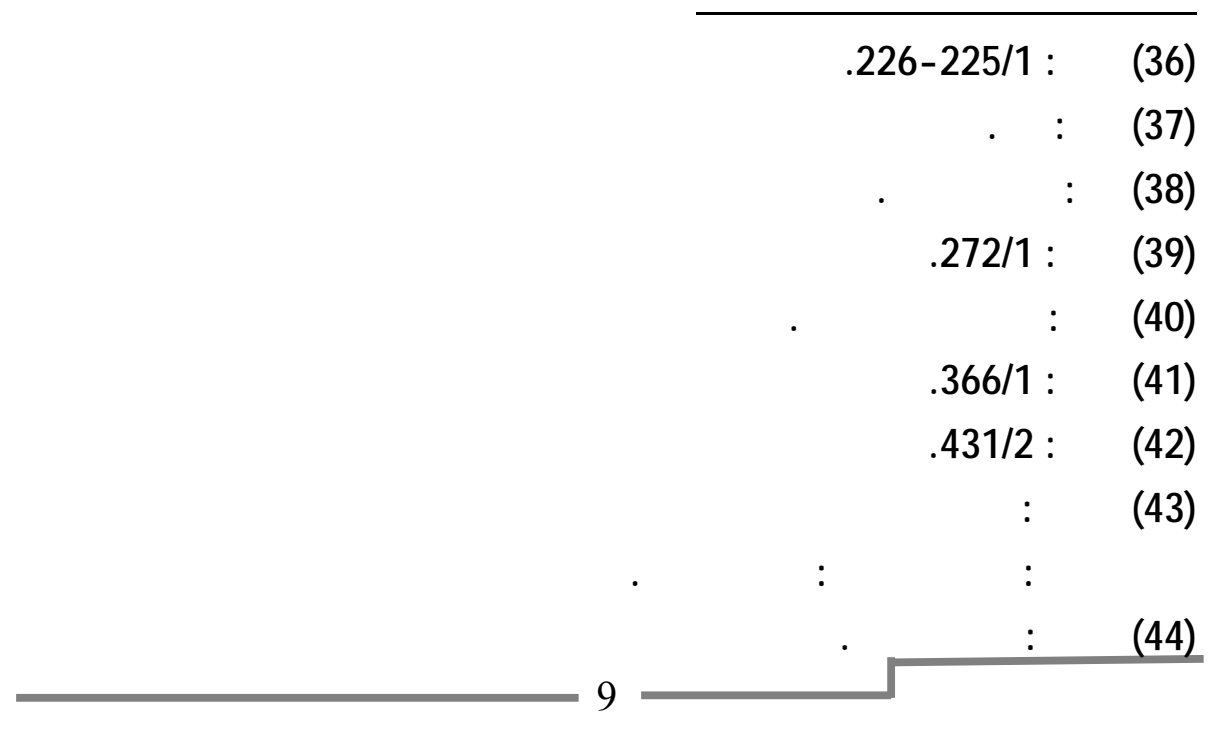




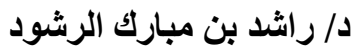

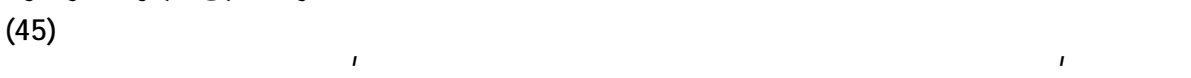

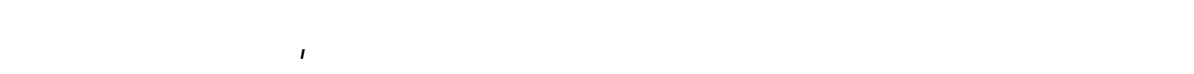

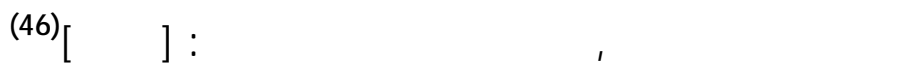

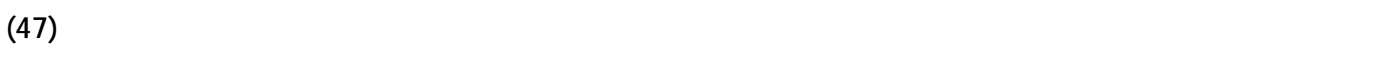

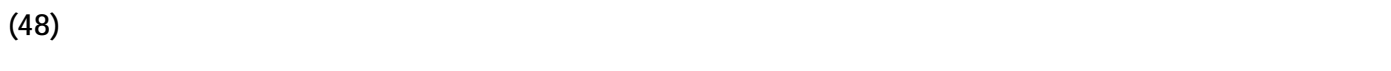

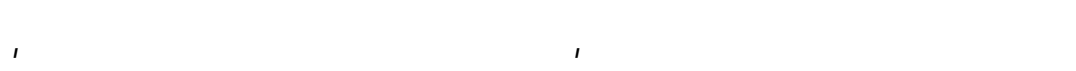

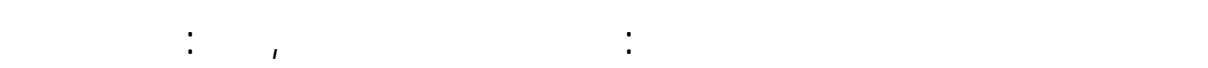

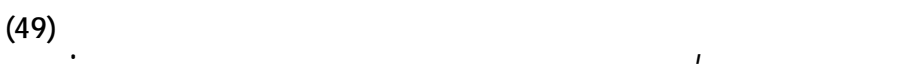

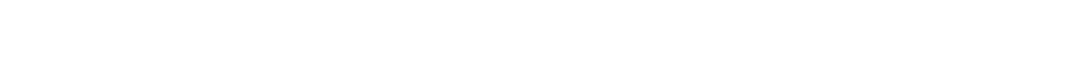

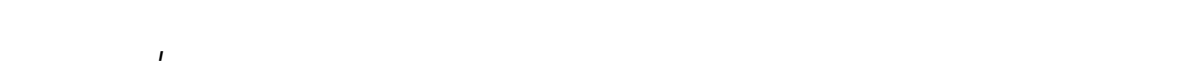

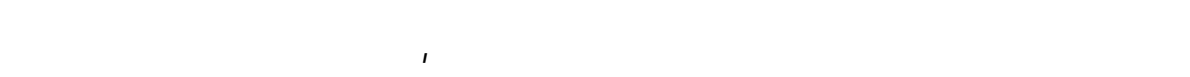
فيها الجحلف مطلعها: [الطويل] (50)

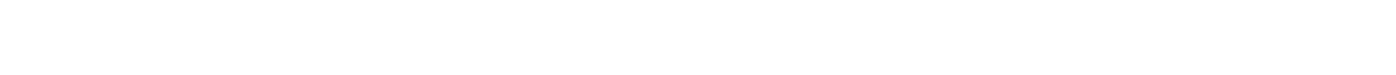
"فقل الجحف: [الطويل]

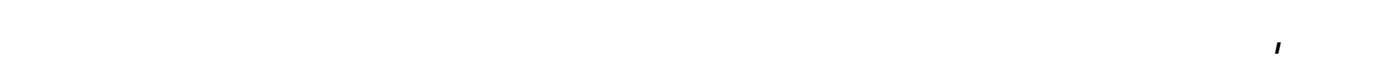

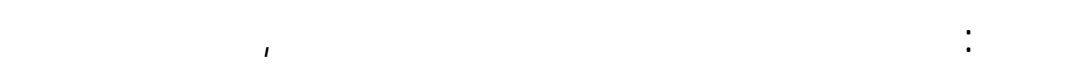

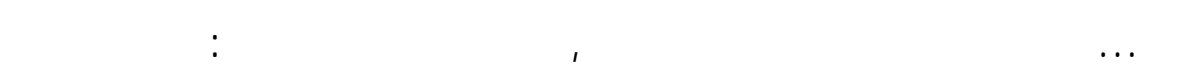

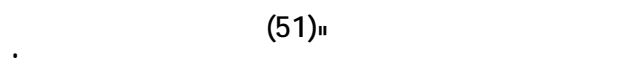

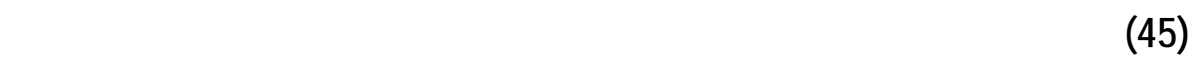

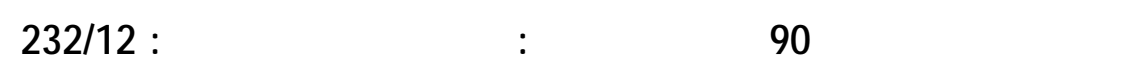

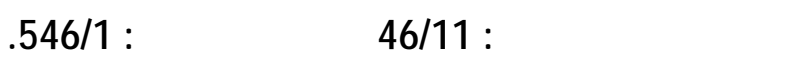

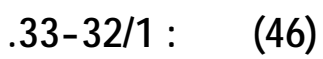

(47) إلهل : الانكل ولاعتماد.

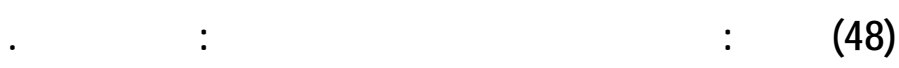

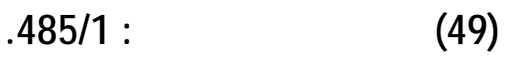

528/2:

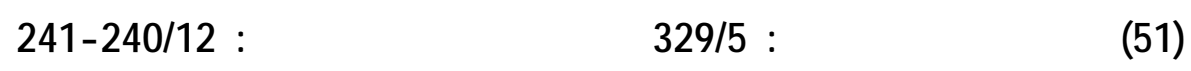
ولهاله، إهولت النالرة:5، والبخداي، خزلة الأهب: 483/9.

مجلة بحوث كلية الآذب 
وكان من صفاته التي أورثها ماسبق من الأسبلب كثرة الوَّلَ ؛ فنرى في

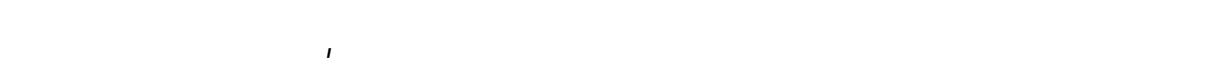

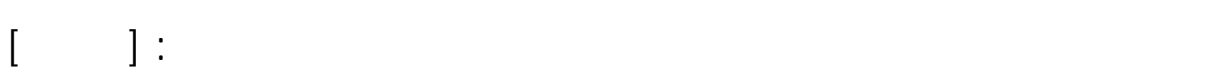

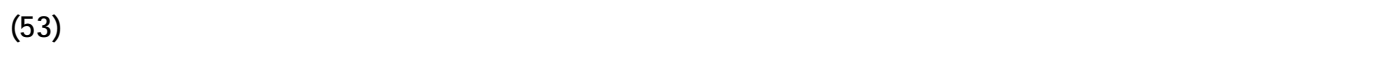

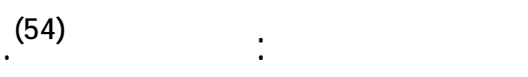

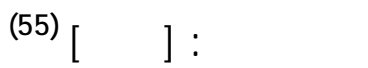

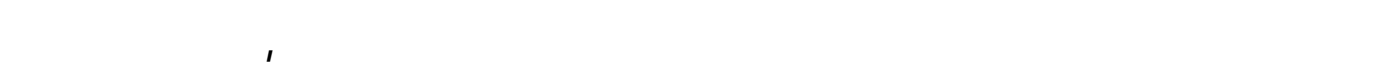

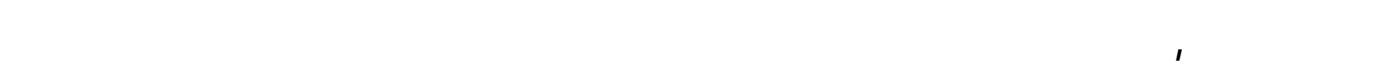

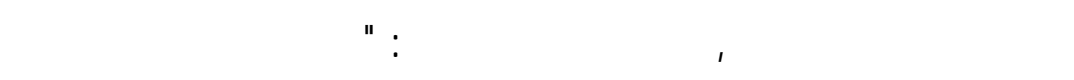

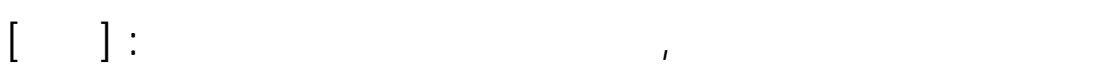

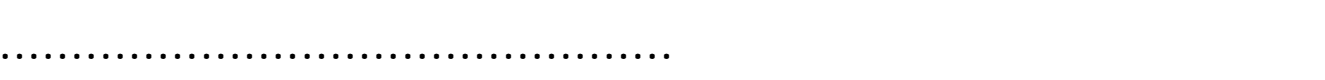

فتحرك الوليد, فقل : مطعل يا جرير, يريد ق صية أوس بـ من مغ _راء(56). [البسط]

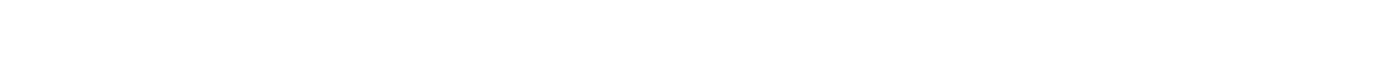

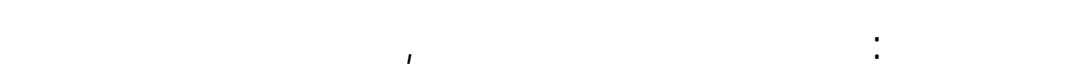

(52) ديوله: 203/1.

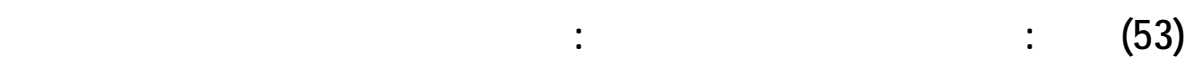

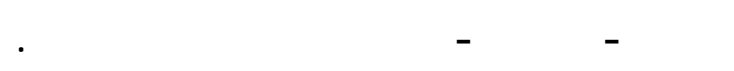
266 (54) المزباله، المكثيح (55) نوله: 202/1.

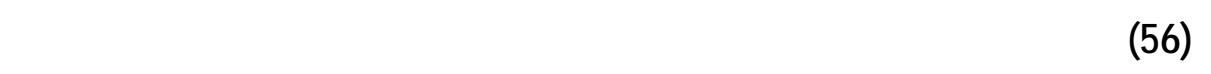

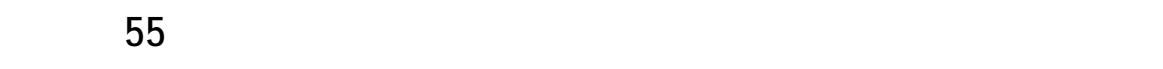

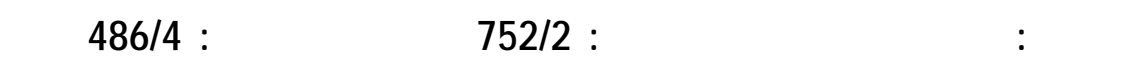

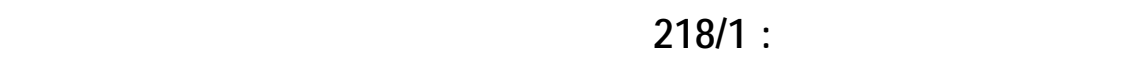

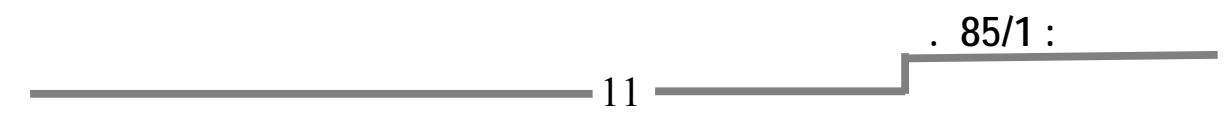


د/ ر راشد بن مبارك الرشود

عبد الرحمن بن هسلن, وصلمب قيس, وصلحب كذا"(57).

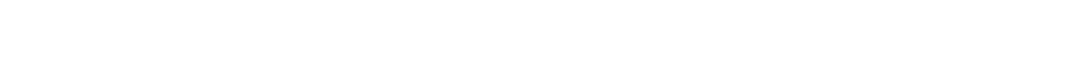

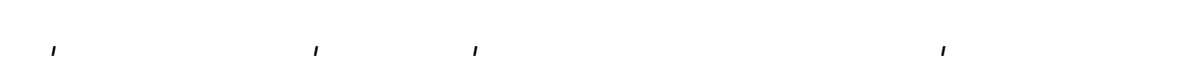

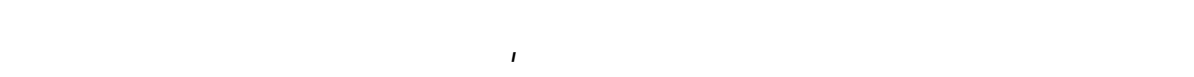

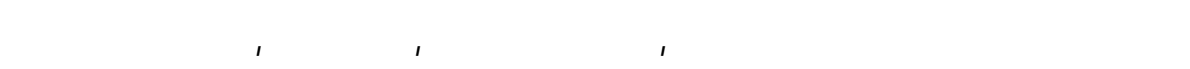
شاربيها.

وساعد على ذالك, أن الأغطل رجل نصرافي, فلسطاع أن يتخطى ح ددود القيود للثرعية التي فرضها الإسلام على المسلمين, وأن يجاهر بـ ـذكر الخم ـرة. ومعاقرتها, والإدملن عليها, وتمجيدها دون أن يخشى رقابة أو عقوبة (58).

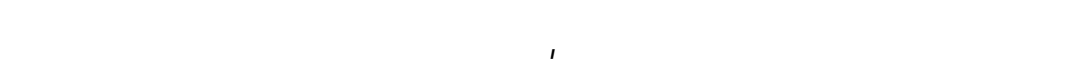
شربها, ويعيب عليه, ويعيره بها, ولكن حبه لها كلن فوق عنل العاذلن, كي ف لا لا

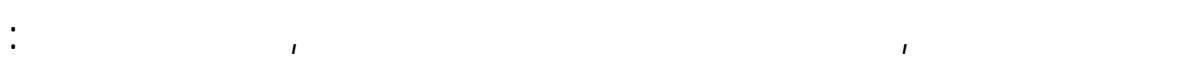
[الوافر][

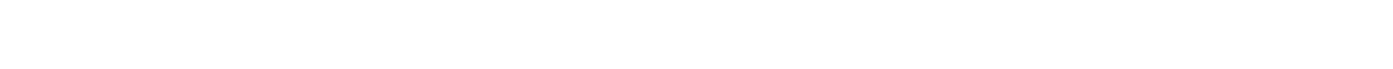
ويبدو أن إمرافه في معاقرتها, وإمانه عليه, قد أوقعته في لوم أص حابه ولحبابه, فضلاً عن أعدائه ومناوئيه, فقد لامته حبيبته ماريه, وألهت عليه في ترك في فئه الخمر أو التخفي منسطيط فمتها على جوانحه على الأقل, ولكن لم يأبه لهذا اللا -وه والإلحاح بل قل:[الطويل]

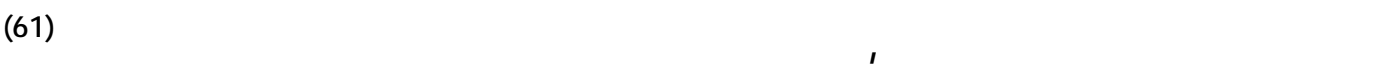

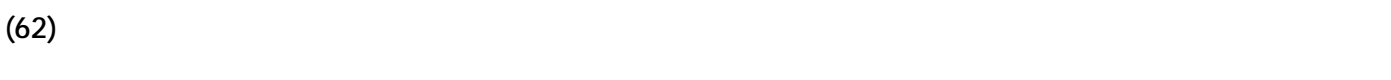

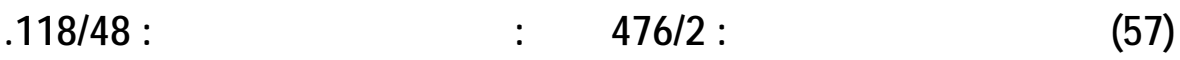

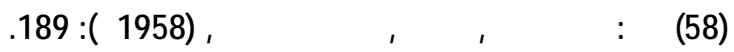

$$
\begin{aligned}
& \text { (59) ديواله: 762/2. } \\
& \text { (60) ديواله: 700/2. }
\end{aligned}
$$

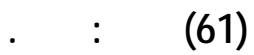

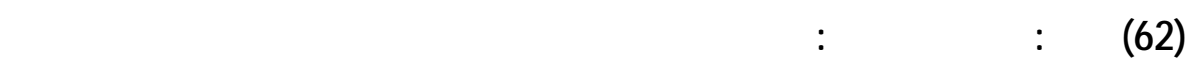




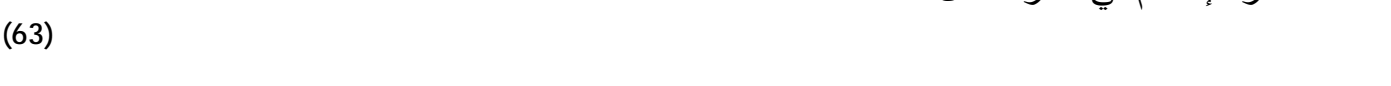

ومع تسليمنا بشربه الخمر, وإمانه عليها, فإن مطق البهث العلمي, يرجح

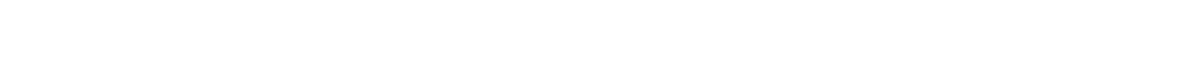

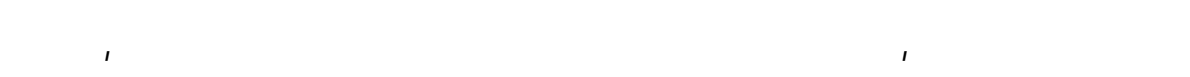

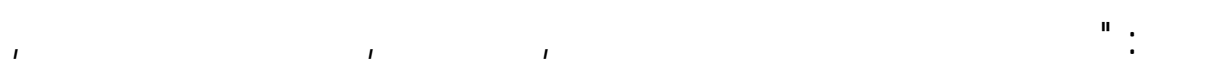
فيها صليب ذهب, تفض لحيته خملا, حتى ينظل على عبد الملك بن مروران بغير

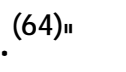

فمهما بلغت الجرأة بالأخطل, ومهما زالت الكلفة بينه وبين عبد الملك, فمن

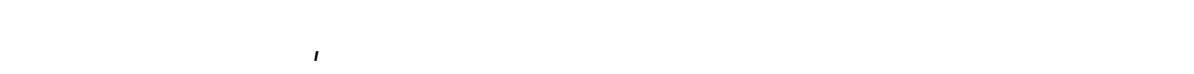

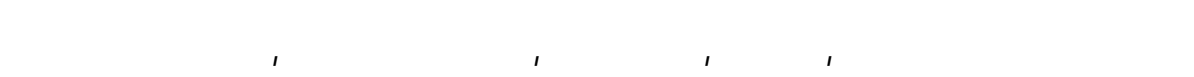

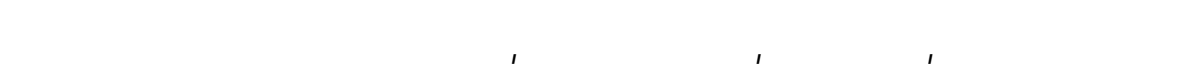

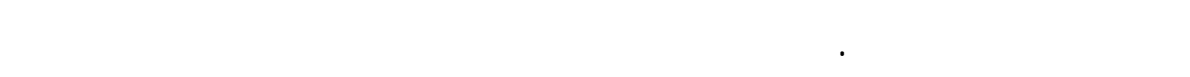
اللثرعية, فإنهسيكون من خوارم المروءة لعبد الملك, ومن لستهزاء الأخطل بهيبته, ولستخفافه بحكمه .

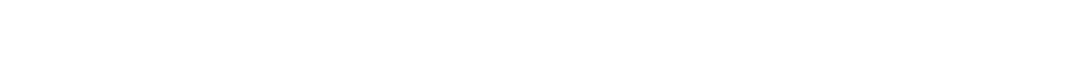

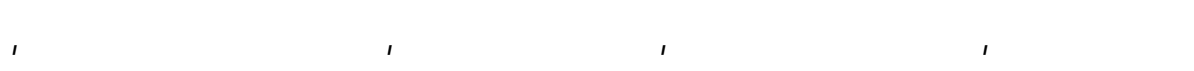

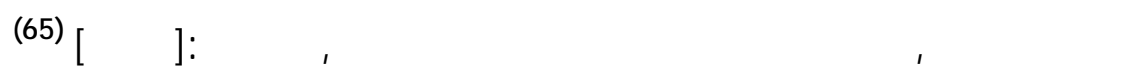

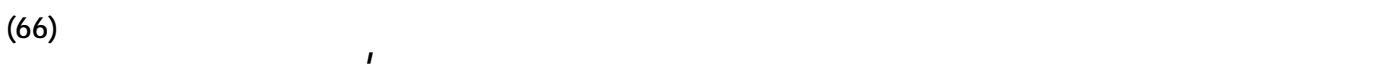

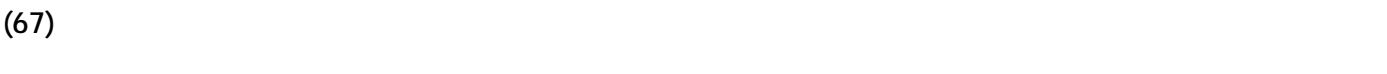

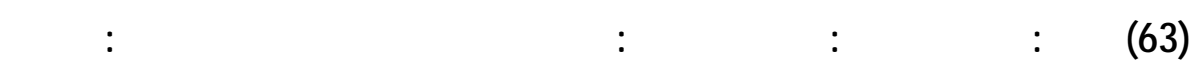

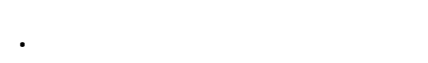

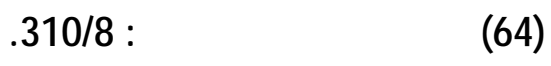

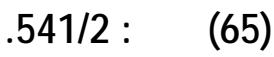

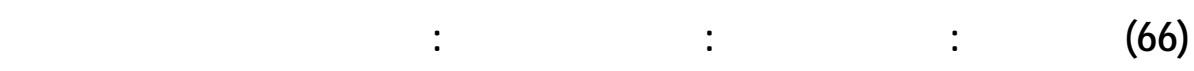

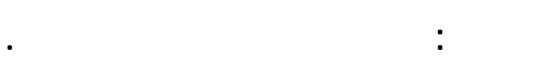

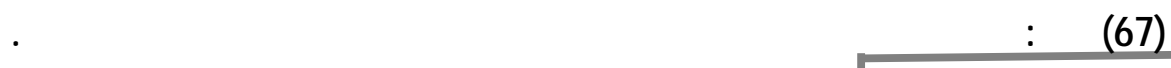
مجلة بحوث كلية الآدب 


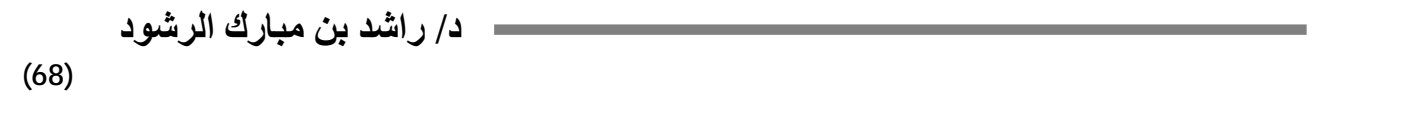

وكما قل أيوضا يصف ليلة قضاها مع إحدى صولحبه: [الطويل] (69)

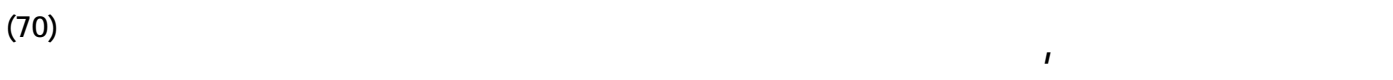

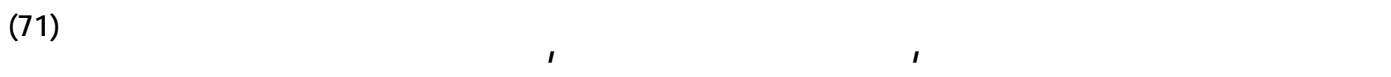

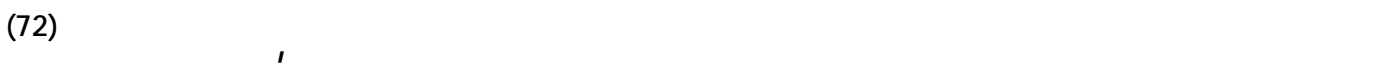

ويعترف في بيت لخر بأفعاله اللساقة, فيقول:[الكلهل]

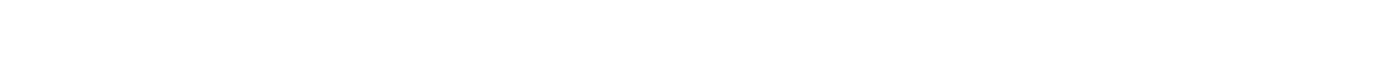

ولكنه فيما يبدو عزف عن هذه للشهوات, وترلجع عن نزولته وجهالات ه,

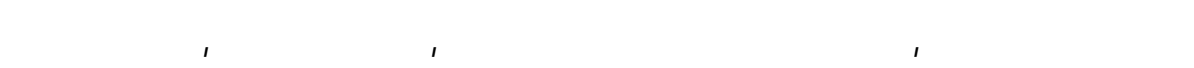

$$
\text { ذالك:الطوبل] }
$$

ق -

$$
\text { ويقول أيهزغا: [الوافر] (75) }
$$

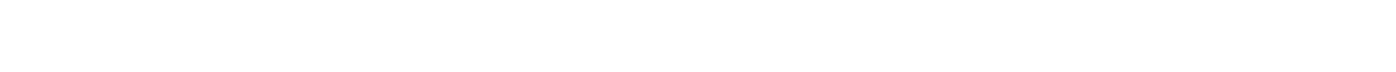

ويبلغ به التعل والرزانة, وترك الجهل والغواية, درجة يكون فيها حكهيا

يصدر حكمته الرائعة, كما في هذا البيت:[الطويل]

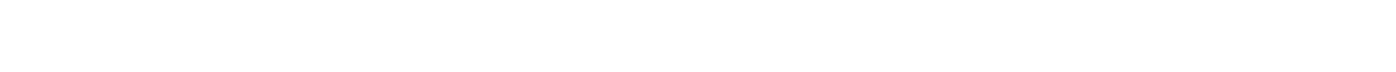

(68) مكك المن: ألمانأ فهـ.

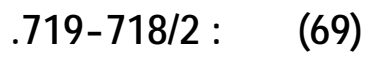

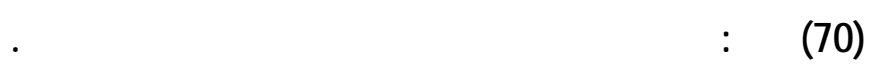

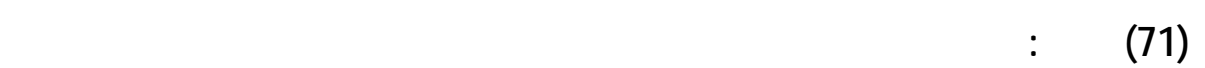

مالاشقطلع لن تهله إله.

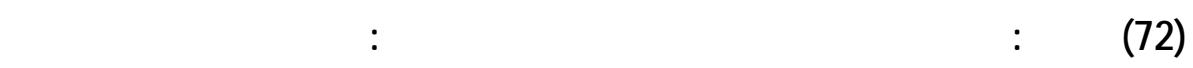

والتولهر.

(73) (73/1)

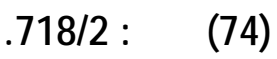

332/17) (75) نوان.

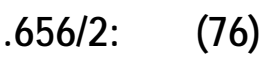

مجلة جوث كلية الآدلب 


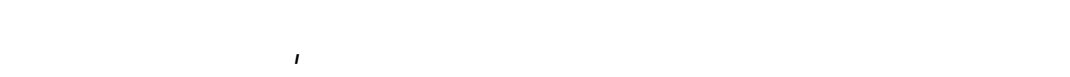

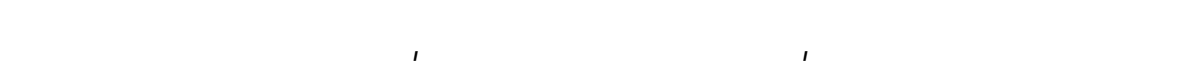

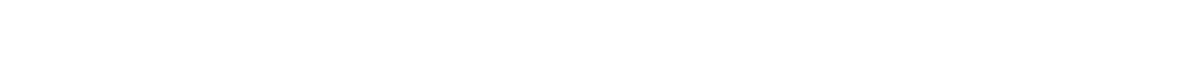

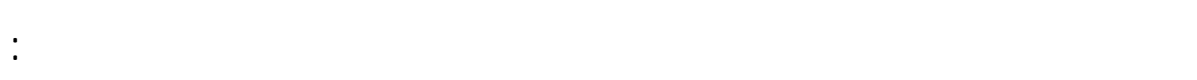

$$
\text { (77) [البطيط ] }
$$

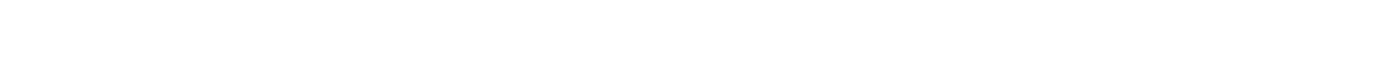

لا يل على أن الثاءر نصراني, إذبإمكان أيشاءر مسلم أوجاهلي أن يقول مل هذا البيت.

$$
\text { وإذا ظررنا إلى قوله: [البسط] }
$$

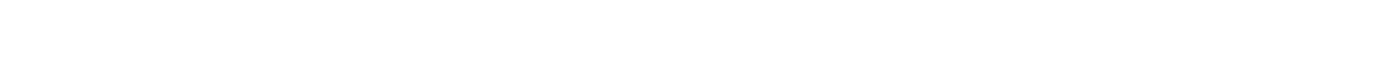

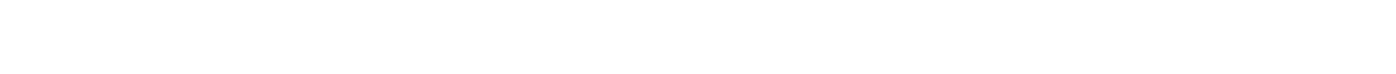

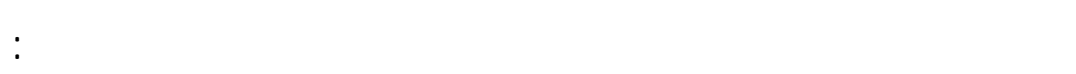
(79) [البسط]

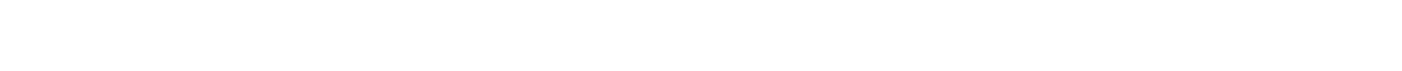

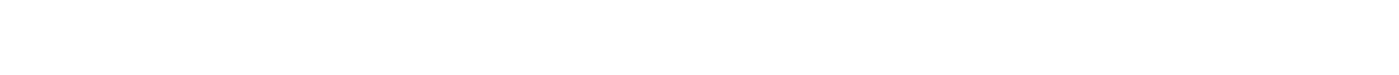

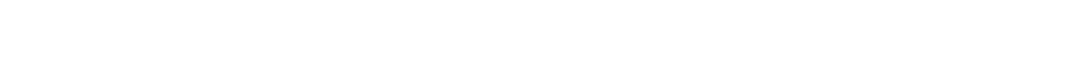

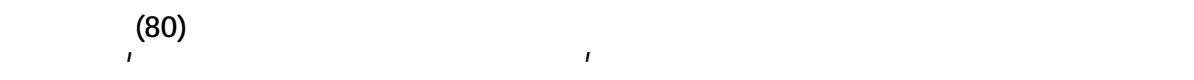
لتغلب على قيس: [ارجز] (81)

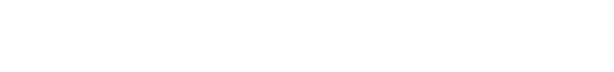

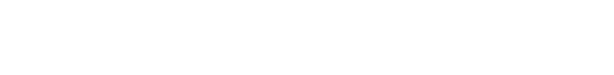

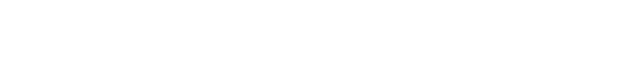

(77) ديواله: 56/1.

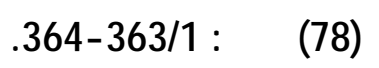

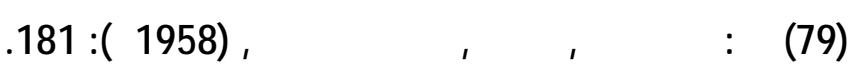

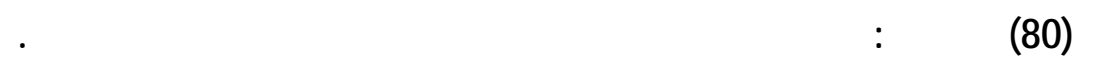

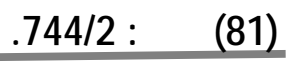


د/ د ارثد بن مبارك الرشود

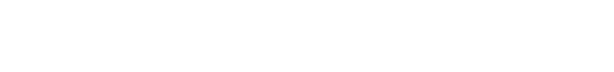

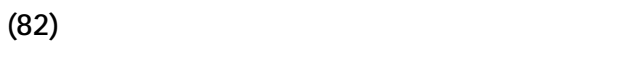

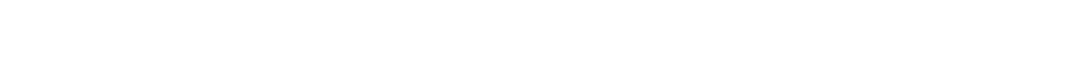

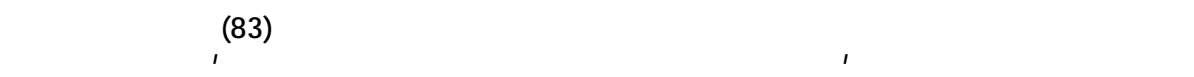

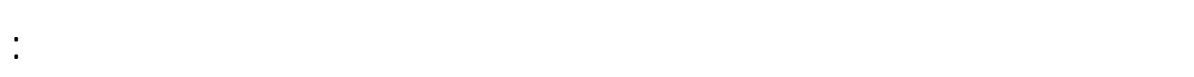

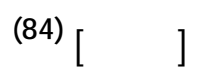

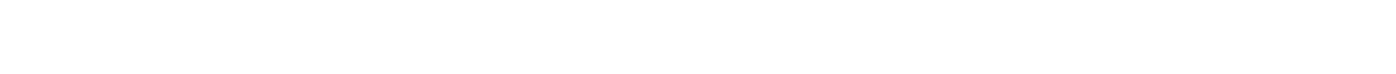

因

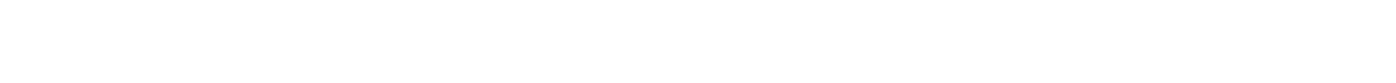

ويتضح في هذه الأبيات لمتخفافه وهزيه ببينه.

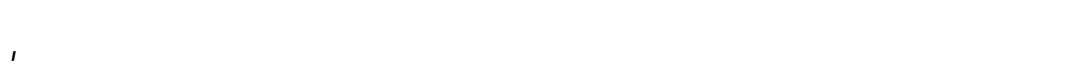

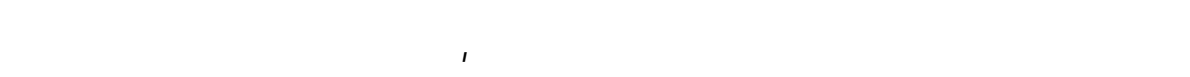

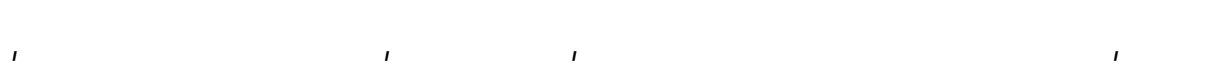

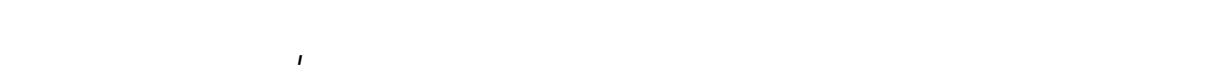
حد بعيد - n

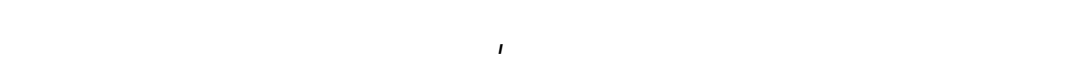

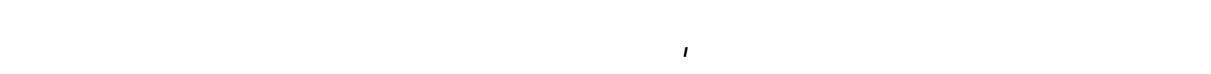
من صفحك ديولنه إلا ونلمسه فيه ؟!

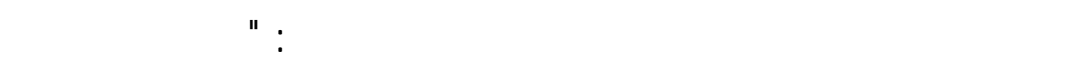

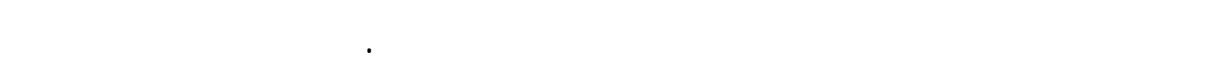
دأيها (هكذا) لوصف الين"(85)

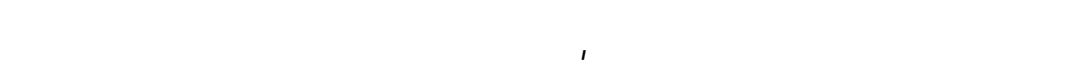

(82) رنال وطرلعز من ديارقيس. (83) نيوله: 129/1.

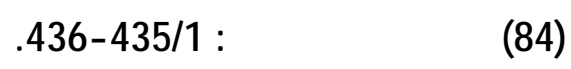

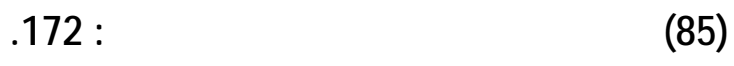
مجلة بحث كلية الآدلب 
مجل القبوله الآن بعد أن وصلنا بروايلت موفقة محققة كرولية السكري عن الب نن حبيب.

و أما قوله بعدم وجود داع لوصف الين, فهذا للسبب لا نسلم به أي هـنها,

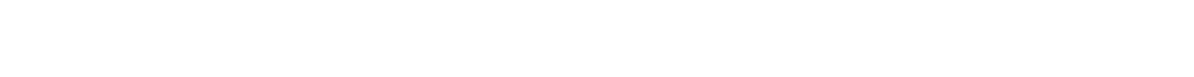

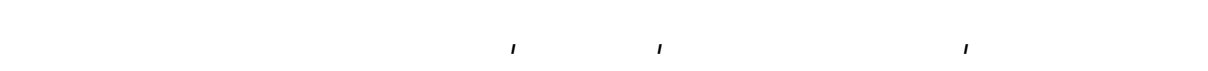

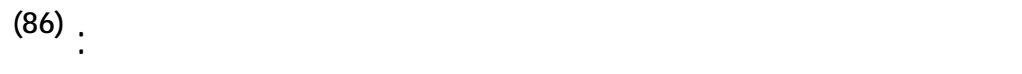

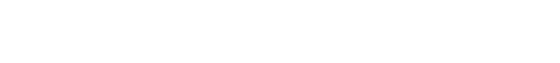

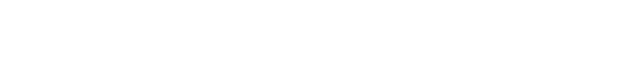

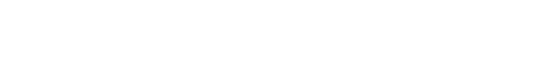

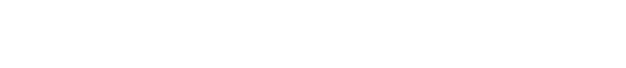

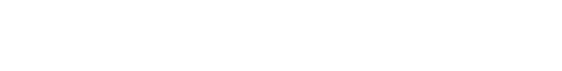

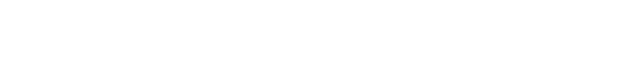

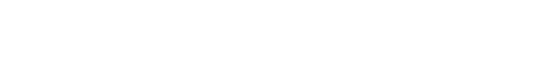

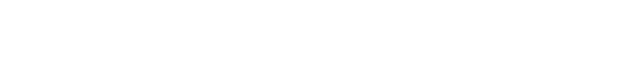

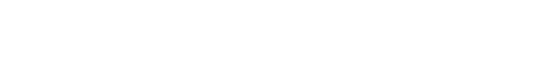

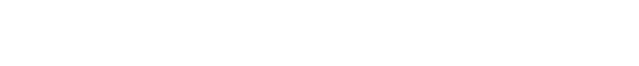

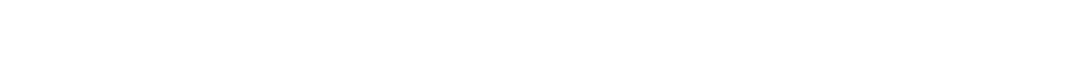

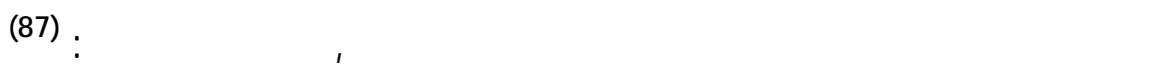

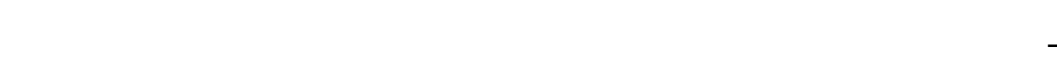
بوصف الشعر

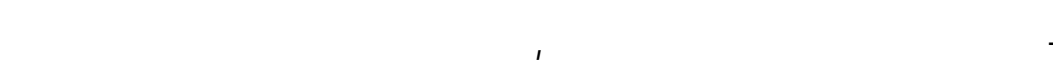

$$
\text { بشيء من النصرانية. }
$$

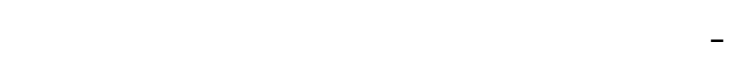

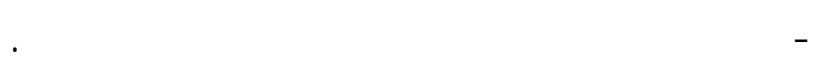

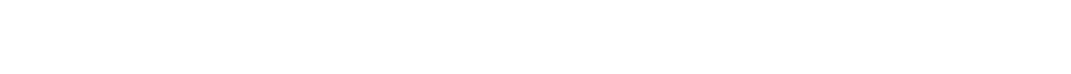

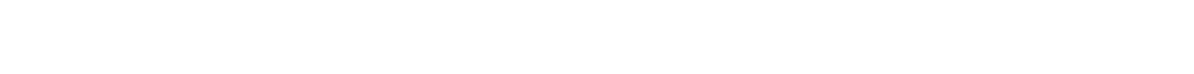

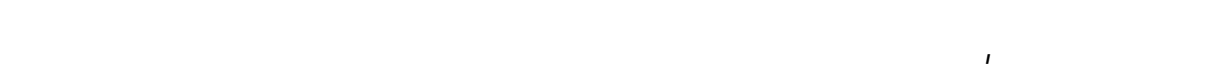

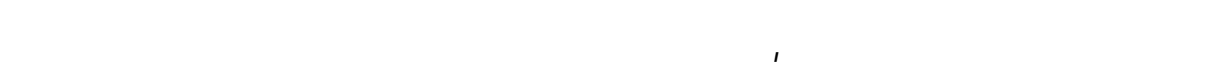

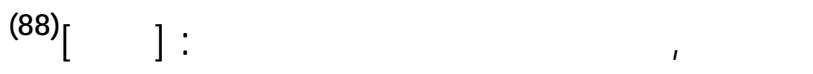

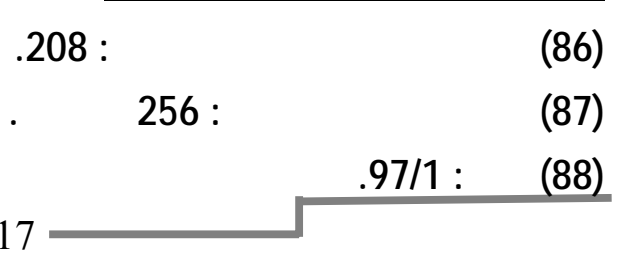


د/ راثد بن مبارك الرشود

B

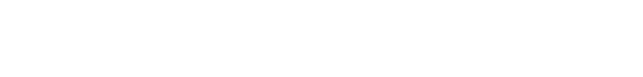

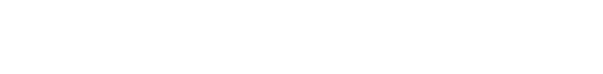

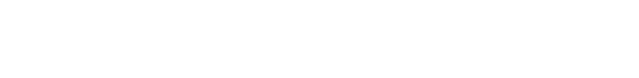

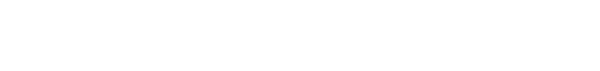

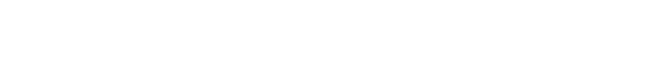

ثانيهما: أن الأخطل قد لا يكون مقتلعا بدينه النصراني وسوف نناقث هذا

\section{لماذا لم يسلم الأفلى}

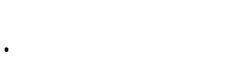

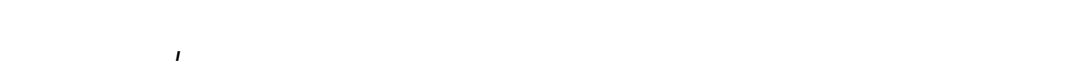

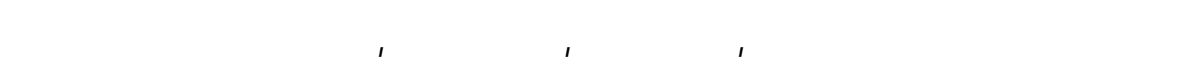

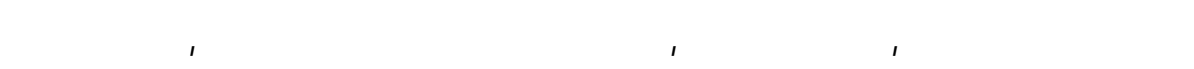

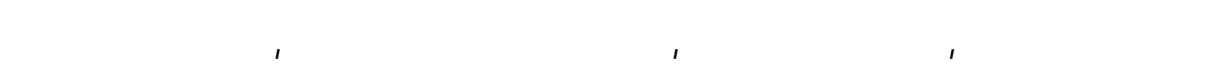

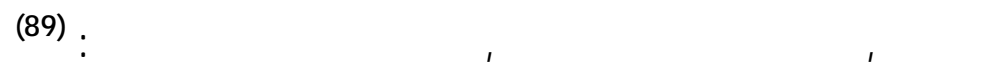

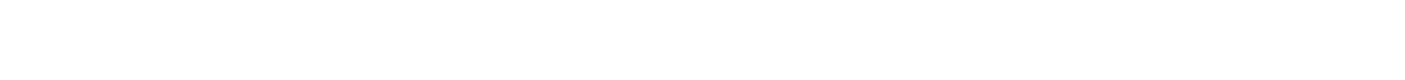

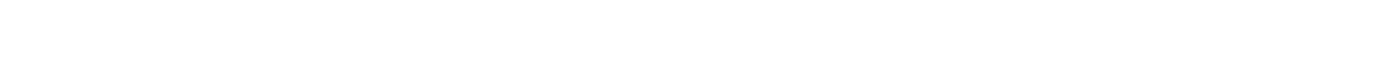

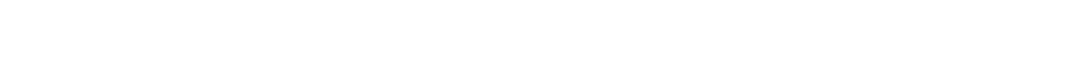

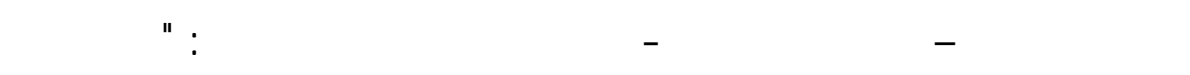

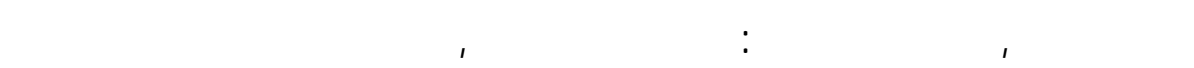

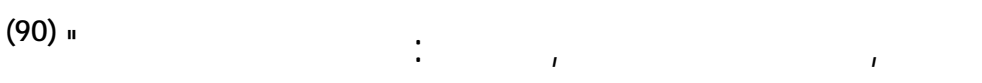

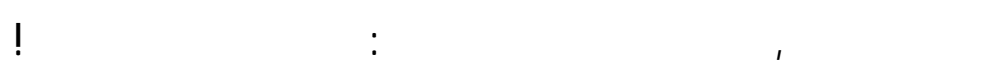

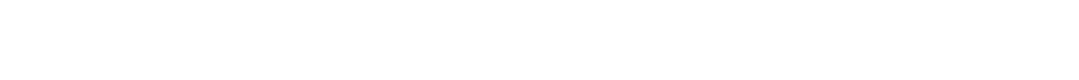

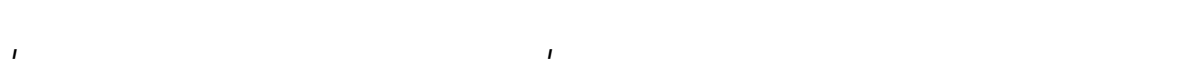
كما وعدوه بذلك, وسيكون موضع عنايتهم والقرب منهم.

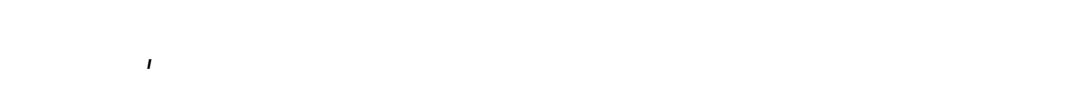

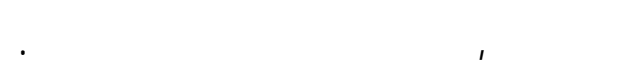

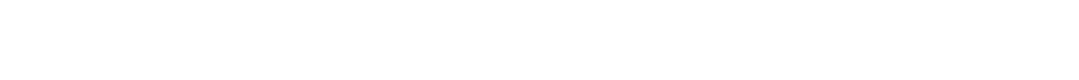
الظظوة والمحبة في قلوب الناس, وستخفي تلك الظرات التي تمقته, وتسخر بـ ـه, 
وتحقرششأنه, وتستكثر عليه وصوله إلى بللط الخفاء, ودور الأمراء, مـ ع كف -ره

ومجونه ؟ ون

وتأتي الخمر على قائمة الأسبل الني يتعل بها الأخطل في عدم إسلامه,

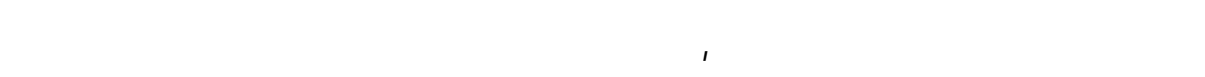

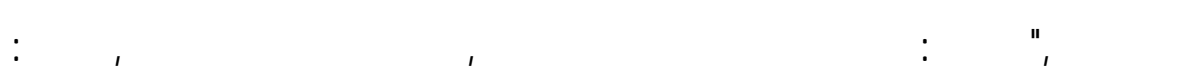

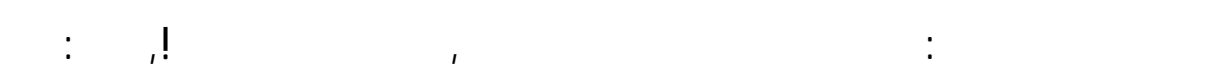

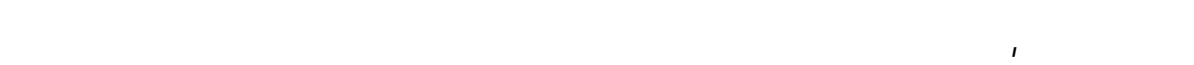

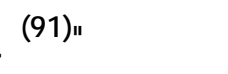
ويبدو أن الأططل التخذ هذه العلة - وهي تحريم الإسلام للخمر - ذريع في لعدم الخخول في الإسلام مع قناعته فيما يبدو أن نصرالنيته كلتت عبئًا كبيراً عليه،

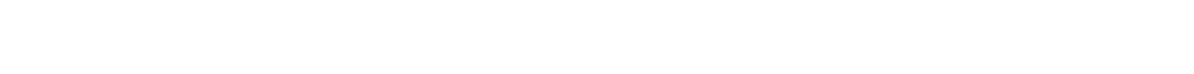

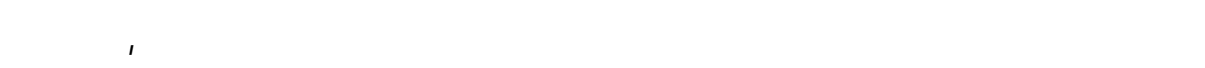

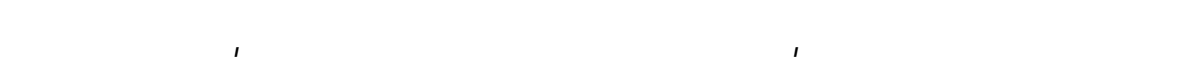

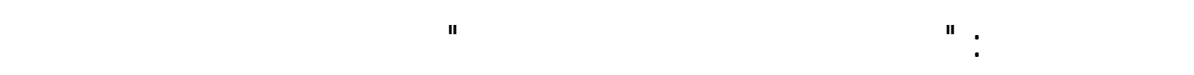

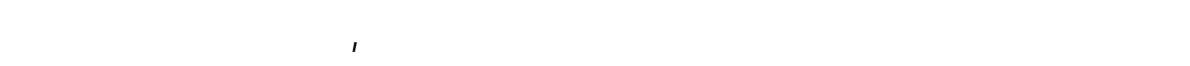

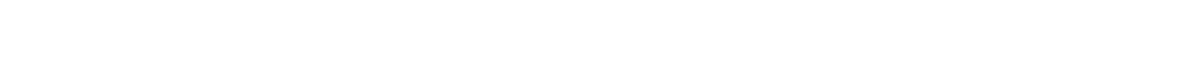

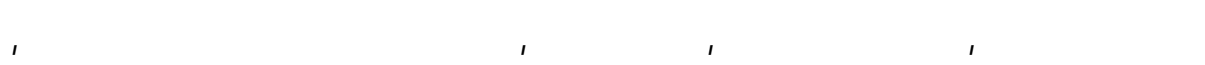

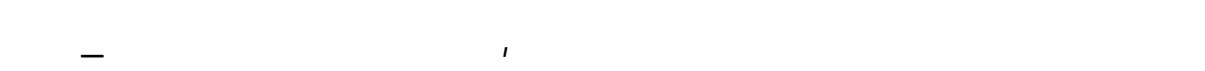

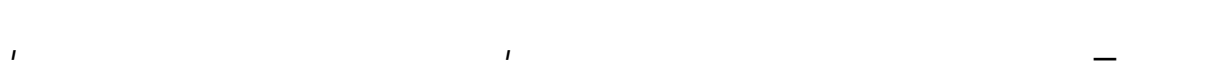

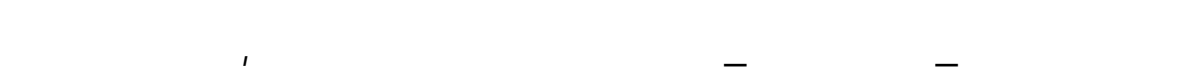

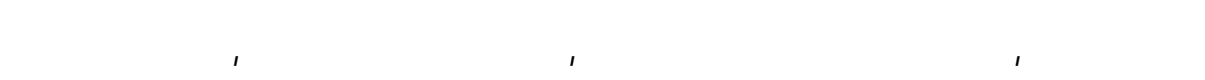

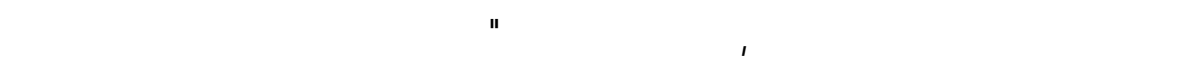
في اعتناقها للدين الجيد تنازلاًمنها' (92).

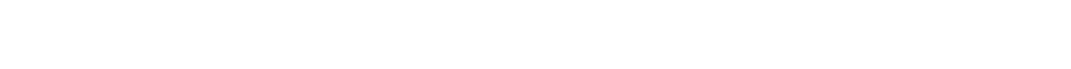

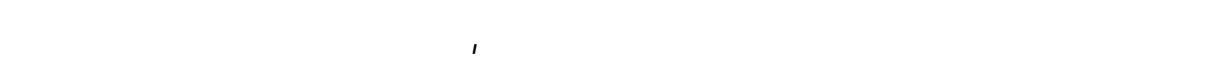


د/ راشد بن مبارك الرشود

والحوار, والأخذ والرد, إله هذا الموقف الحسلس ال ذي تنك ششف في ـه أوراة هـ, ويفتضح لمره, وقاهر فيه مكنونلت صدره . والا أعلم .

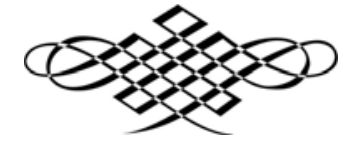

\section{المبحث الثافي \\ الهقائد الإسلامية فيشهر لأذل}

مفهو الألوهية فيشمرون

للثك أن هنك تباينًا واضضاها في مفهوم الألوهية بين كل م حن الم سلمين,

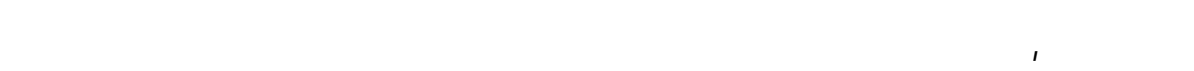
بيئة إسلامية ؟

ستكون الإجابة فيشعره بالتلكيد، ولكننا قل أن نستخلص مفهوو الأخطل

الشخصي عن الألوهية، نحب أن نعطي نبذة موجزة تبين مفهوم النصارى لذاك.

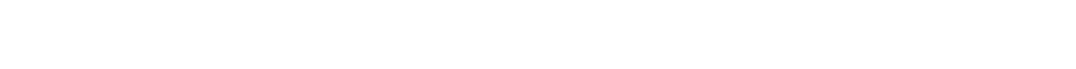

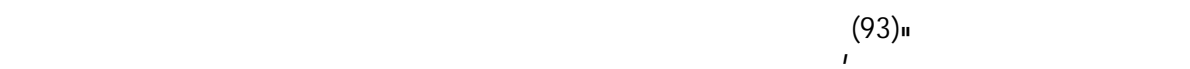

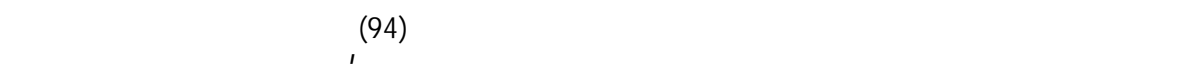

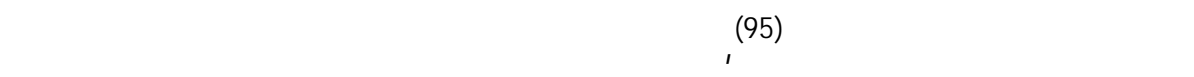
لأسقفن, كان لأحدهما يدعى لأسقف العرب التغلبين ومقلمه بعاقولال(96).

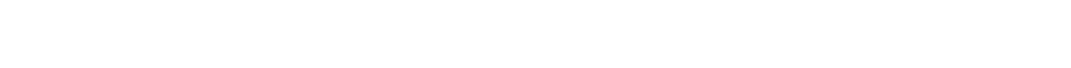
عندهم جوهر ولحد له ثلاثة أقانيم, هي الأب والابن وروح القس، وأن كل ولح ـد القد

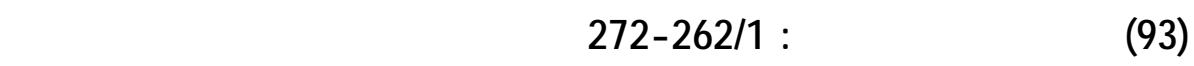
عل عباد الهبي: 134.

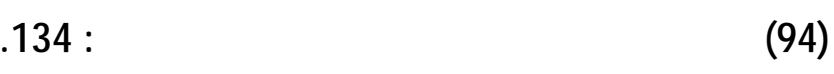

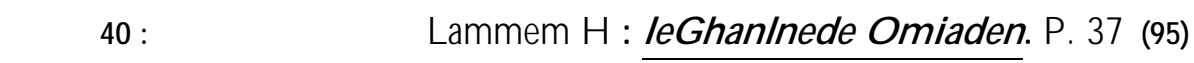
J. S. M eisami and P. Starkey,EdS., Encyclopedia of Arabic Literature, vol. 1, p. 67.

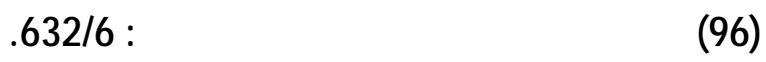
مجلة بحوث كلية الآدلب 
من هذه الأفانيم جوهر خاص، يجمعها الآلئ الجوهر العلم, ولكنه يختلفون في تف سسير

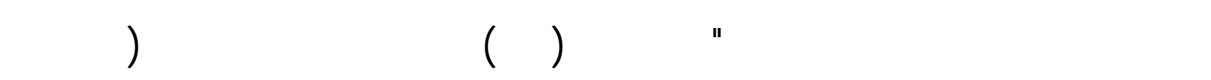

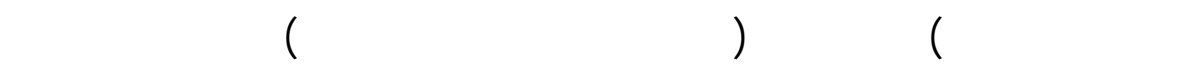

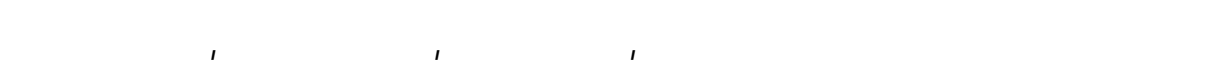

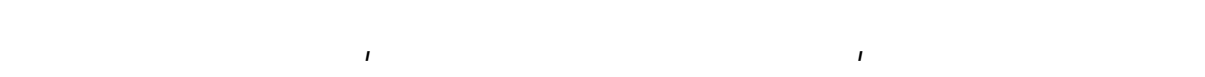

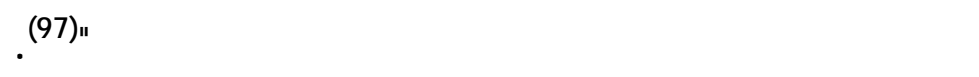

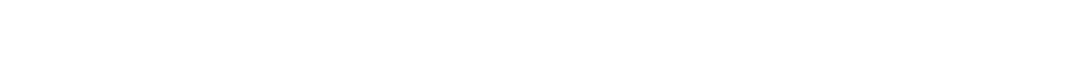

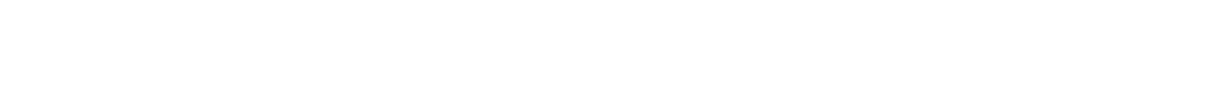

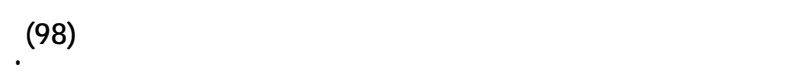

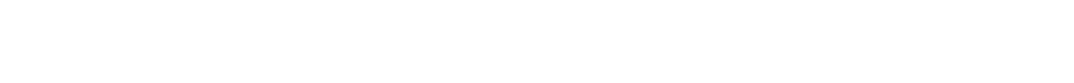

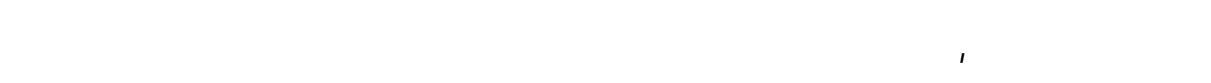

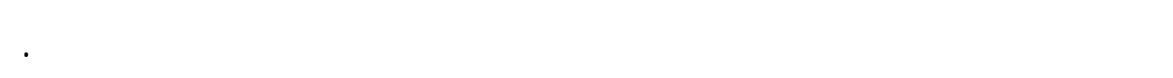

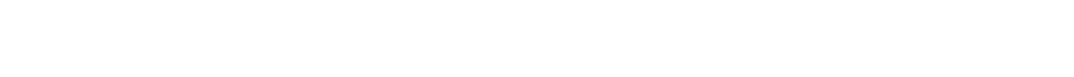

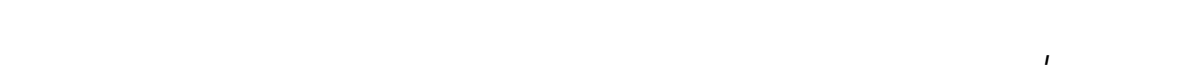

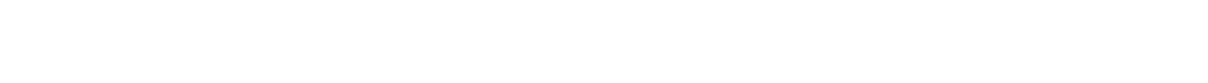

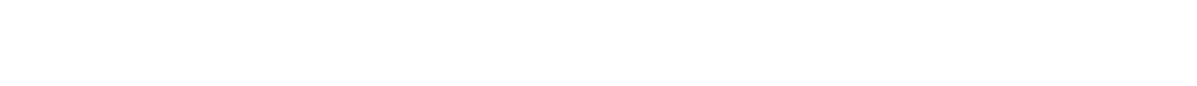

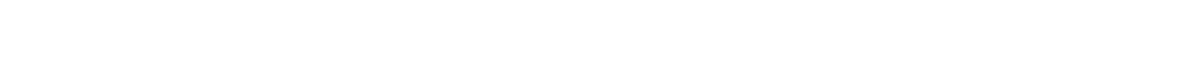

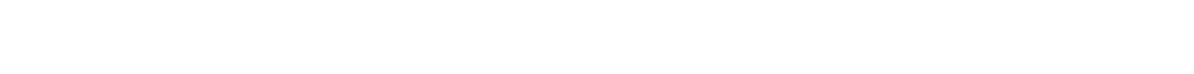

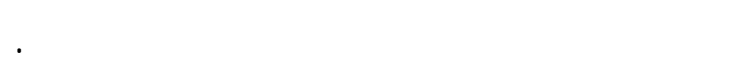

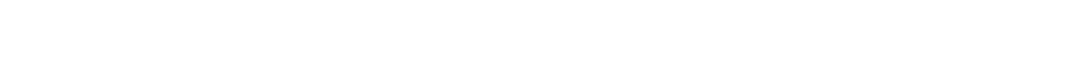

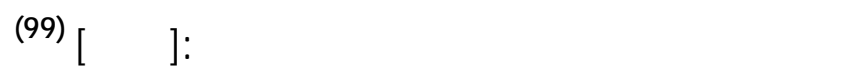

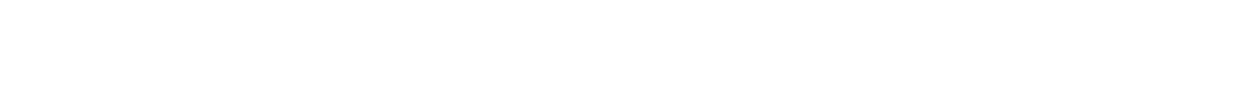

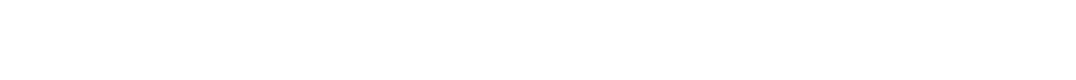

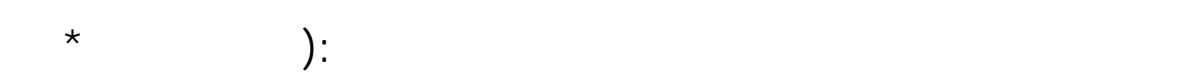

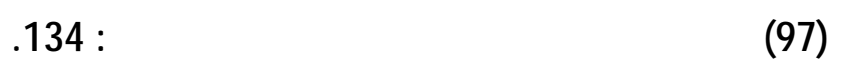
. 154 (98) 727/2 . مجلة بحوث كلية الآدب 


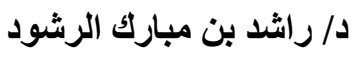

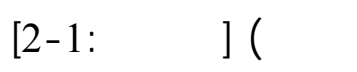

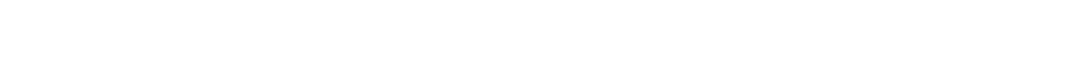

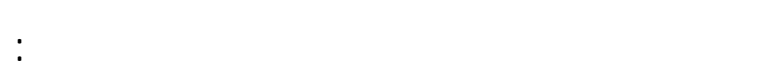

الوالحد الصمد، في قوله من البيت للسابق: [البسط]

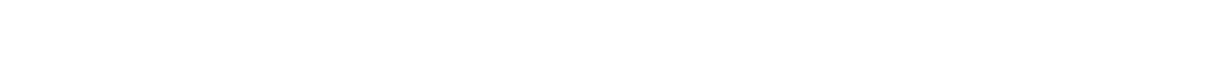

ومعنى الولحد أي الذي لا ظير له ولا وزير، ولاشبيه ولا عدل لأز هـ الكلمل في جمبع صفاته وأفعاله (100).

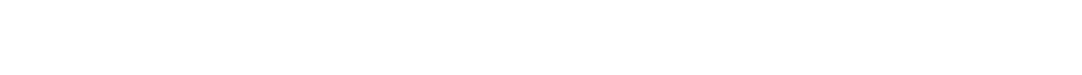

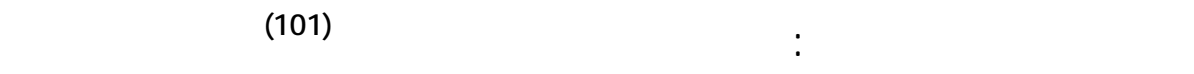

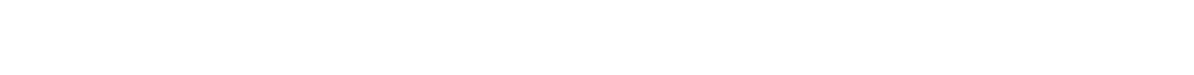

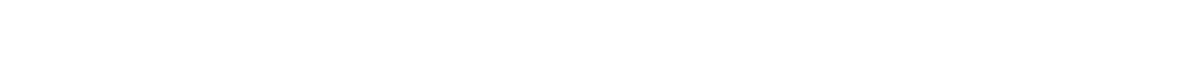

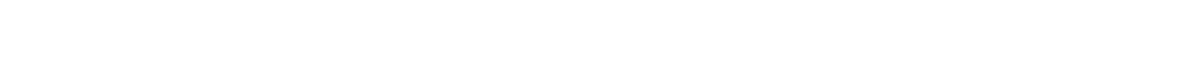

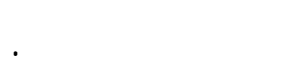

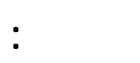

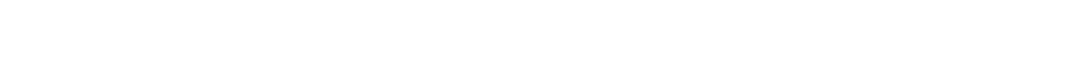

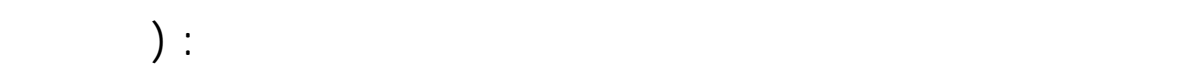

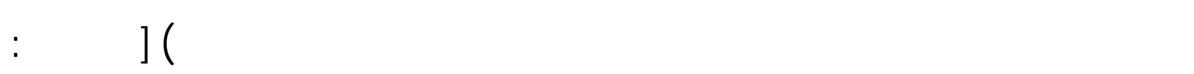
(102) $[60$ أنكر هذا حق أبين أن الأخطل م. بستلهم هذا المبم من ترالثه الجاهلي بل

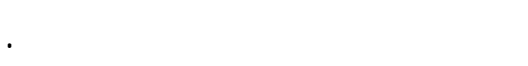
وقد نكر الأخطل لمم (الرحمن) في قوله : [البسي]] (103)

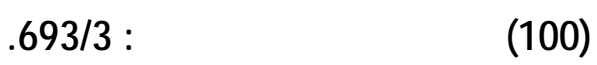

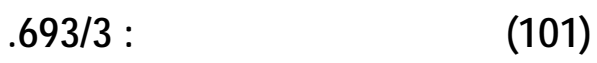

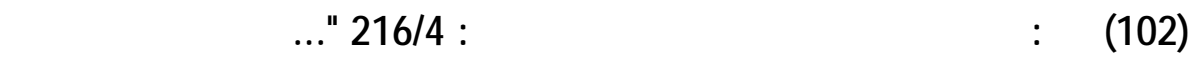

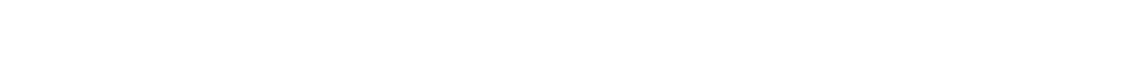

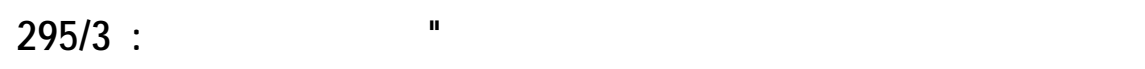

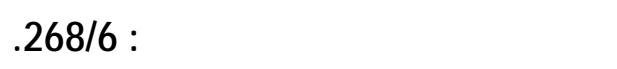

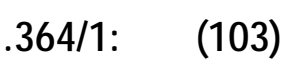

مجلة بحوثكلية الآدلب

22 


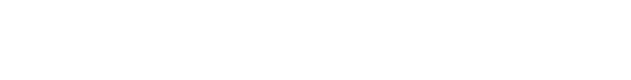

والذي رفعه الرحمن هو محمد صلى ا ، عليه وسلم.

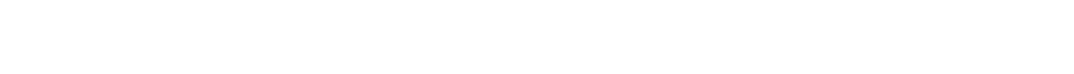

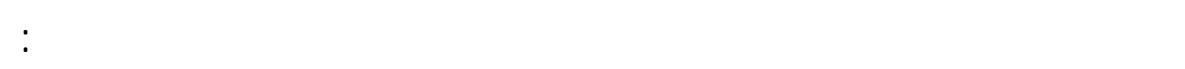

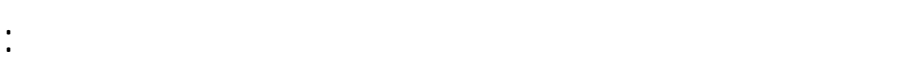

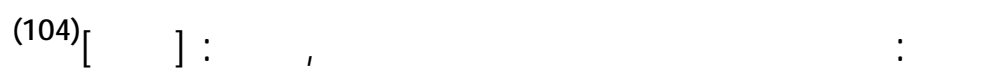

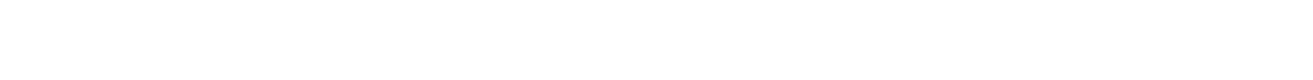

وكفوله: [البسيط]

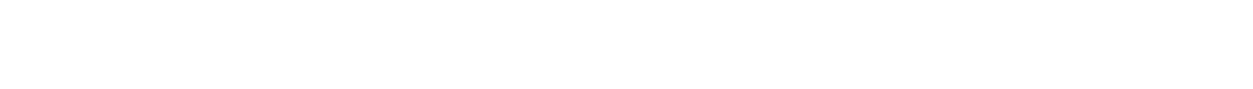

قوقوله : (106)

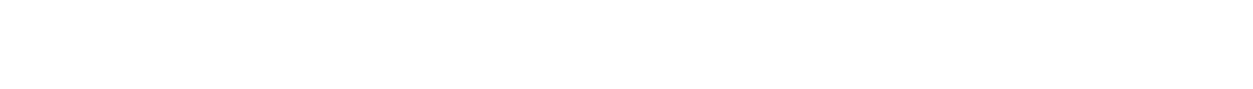

وفي هذا البيت تبرزميزة لخرى, وهي أن ا ، لطستجلب لنوح في لظظ

$$
\text { كربه واضظطراره. }
$$

وقوله : [الطوبل]

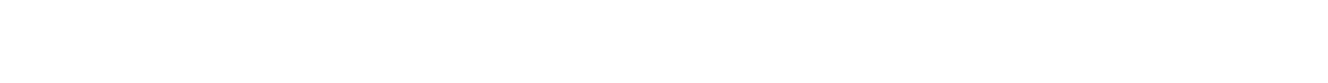

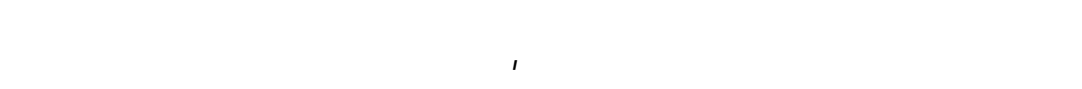

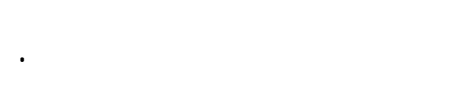

ولجابة الدعاء صفة من صفات ا ، التي نكرها في كتابه, كما قل: (فلّالئي

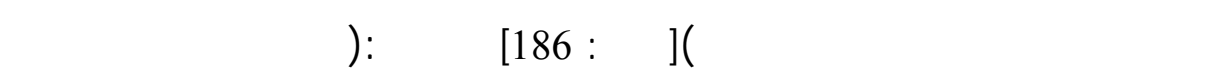

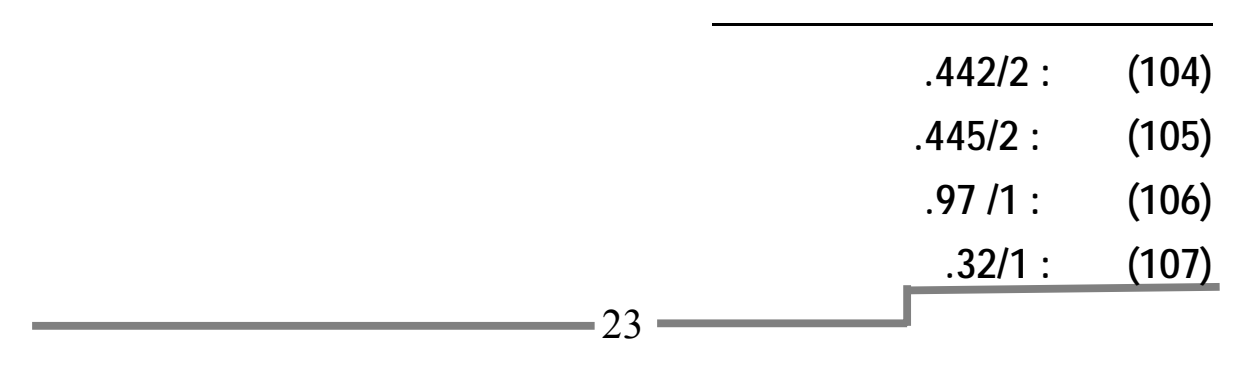




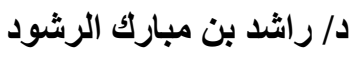

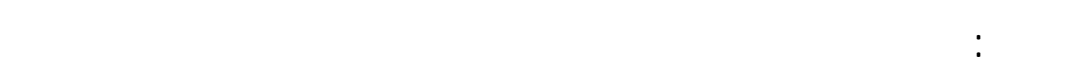

[الن

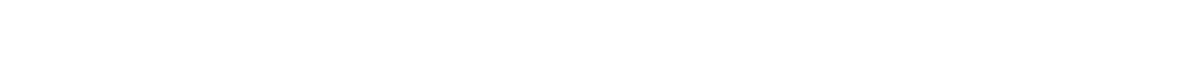
معاوية:[البسط]

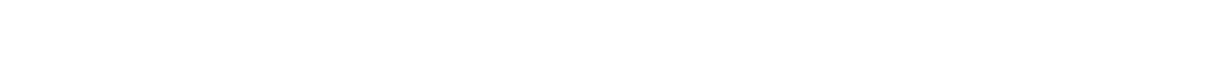

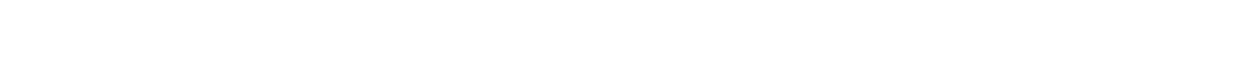

$$
\text { ومن دعائه على غيره، قوله يدعو على بني كليب: [الكلم]] (109) }
$$

i

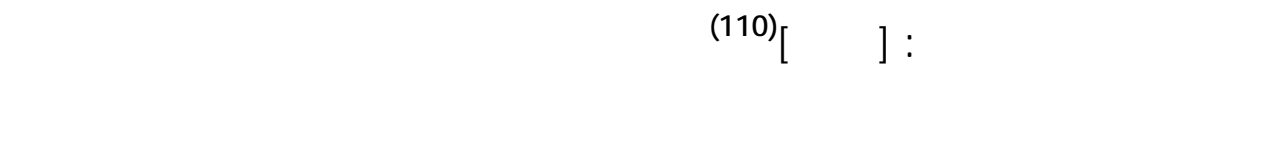

$$
\text { ومن صفاته تعاله: الرحمة، كفوله: [الطوبل] [111) }
$$

ل

ومن صفات ا ، تعاله أيوزيا، العلم، كفوله: [البسيط] (112)

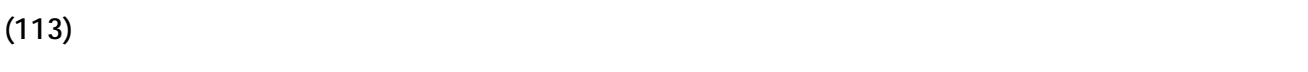

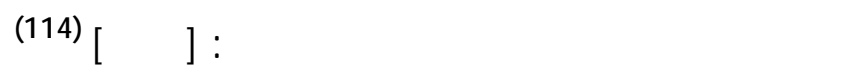

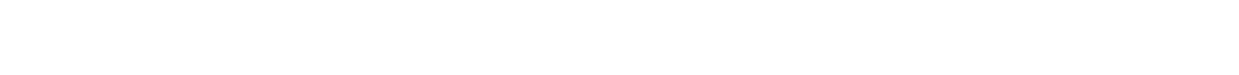

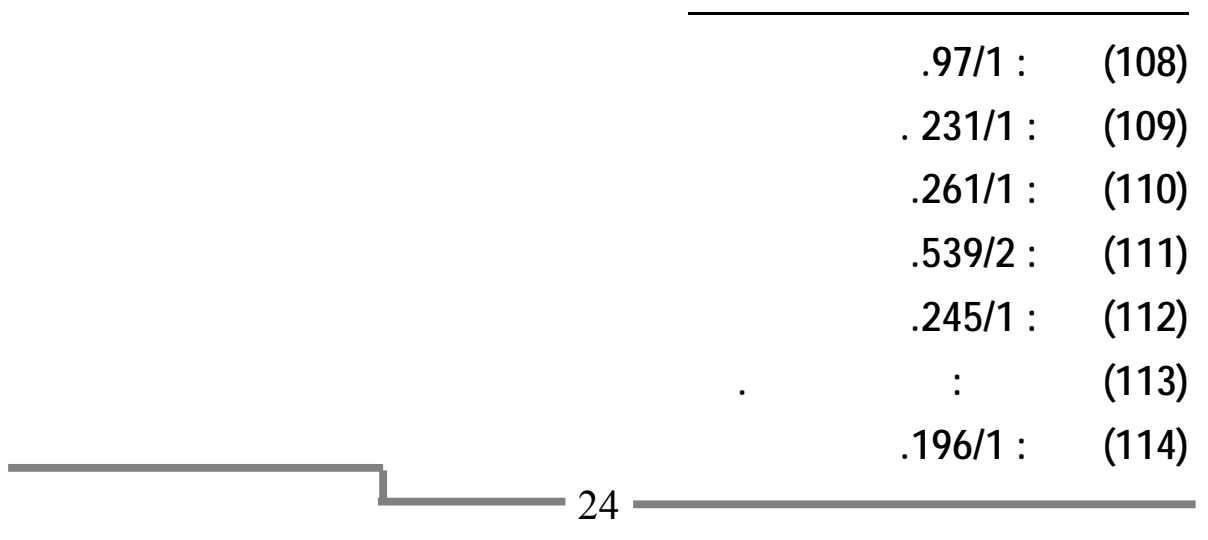


ومن صفاتهسبحانه الرضا والسخط، يقول الأخطل: [البسط] (115)

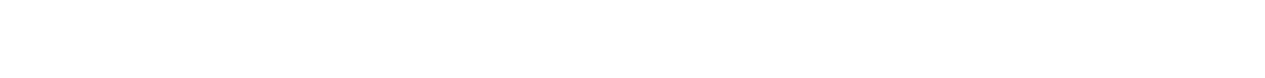

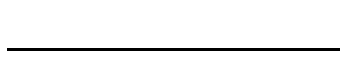

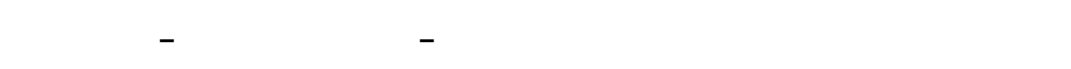
بجلاء ووضوح مفهوم الأخطل لمقلم النبوة.

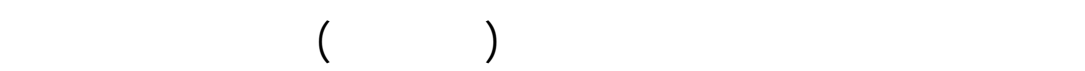

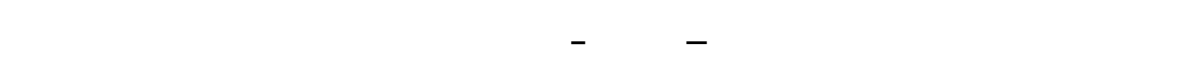
ورد نكرهم فيها .

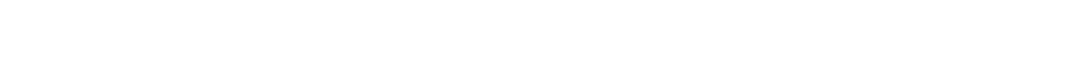
وداود وموسى وهارون، يقطل الأخطل:[البسط] (116)

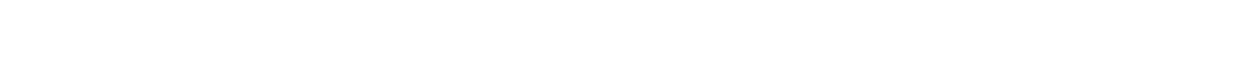

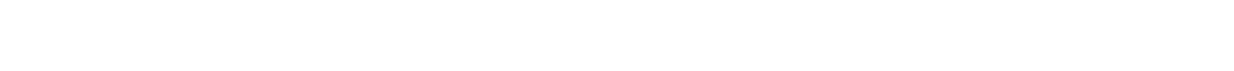
ن

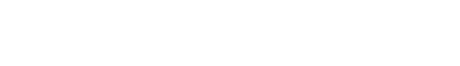

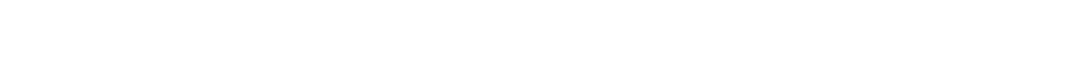

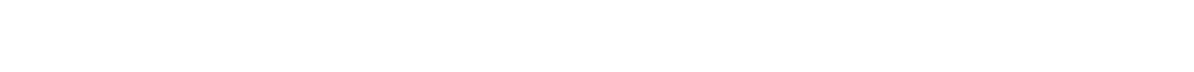

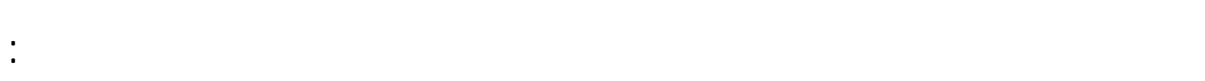
(117)[الطويل]

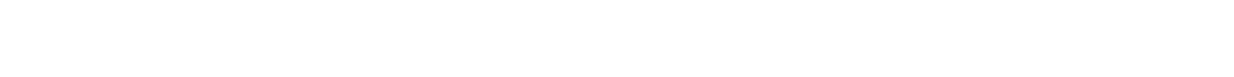

كما أنه نكرسفينة نوح في معرضسرره للأنبياء.

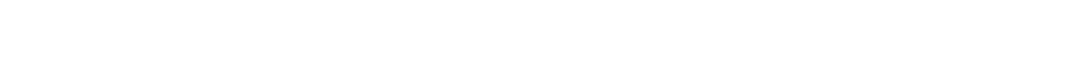
عليه وسلم وهي ختم النبوة حينما قل يهجو بني ألسد: [الطويل] (118)

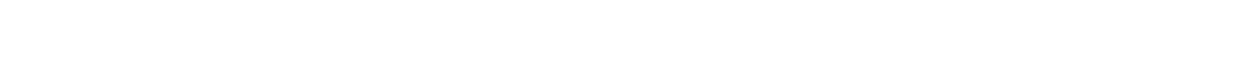

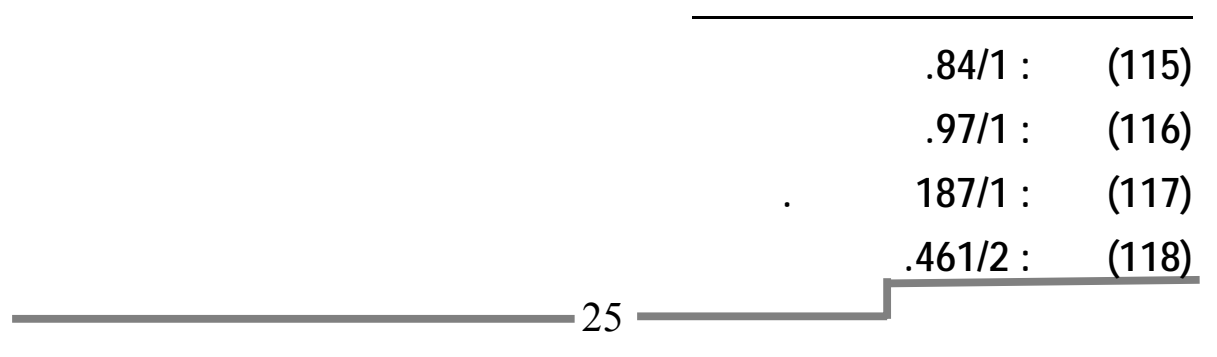




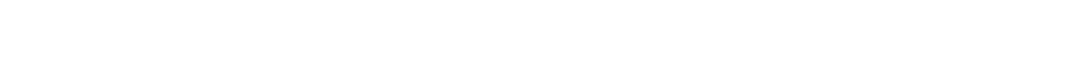

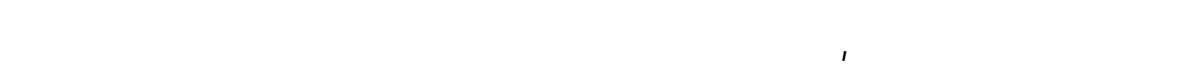

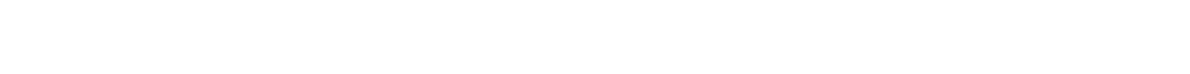

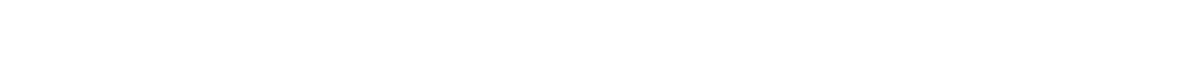

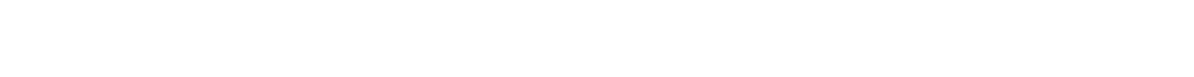

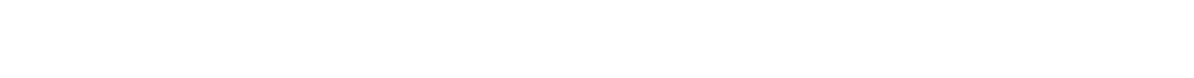

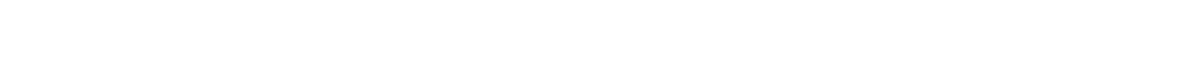

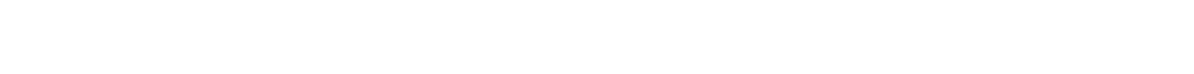

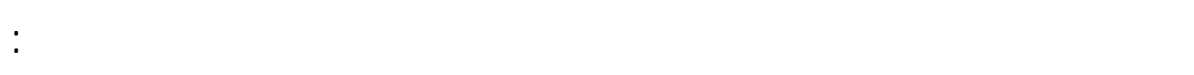
(119) [الطويل]

\section{耳車}

ومع ذلك، فلا ندعي أنه أسلم، وإنما قول فيه كما قل الرسول صـ فله اله

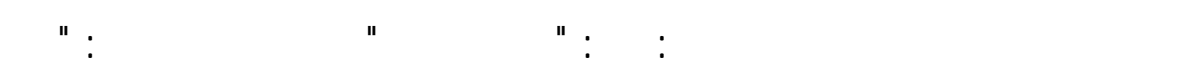
(120)

\section{الكتب المقسة فيشعره}

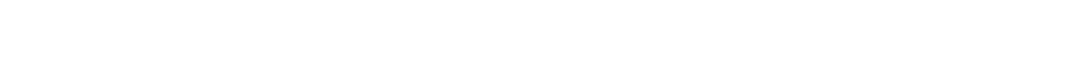

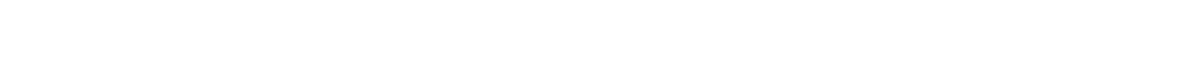

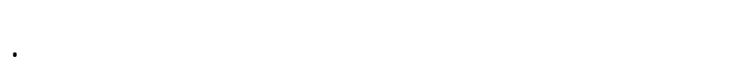

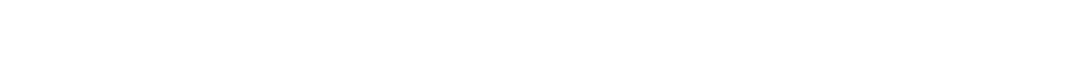

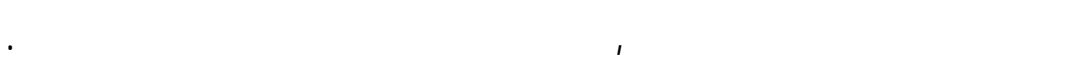

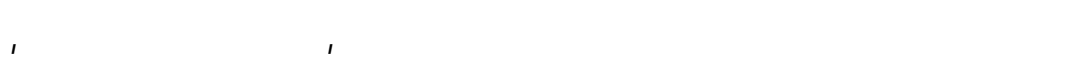

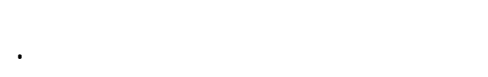
فعنه أن القرآن واضضح لا لبس فيه, لمانه عربي مبين, لذا فتدشبه حكمه 
وقضاءه بين المتخاصمين بوضوح القرآن وبيانه, يقول: [الكلمل][121)

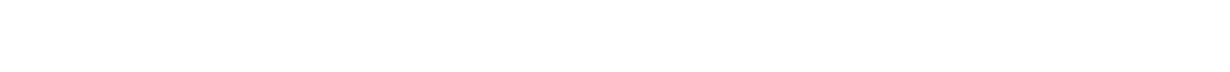

وقد يهجو أقولها، فيكون في هجائه ققريع وتوبيخ لهم على قصصيرهم ف مي

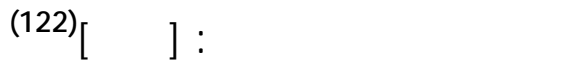

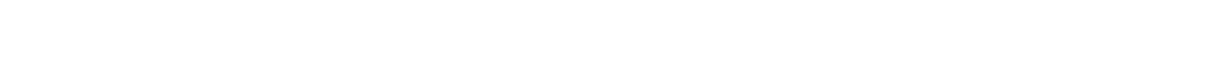

وفي الجانب الآخر فقد تأثر الأخطل بالقرآن في بعض معاني ه وألفلظ ه ه

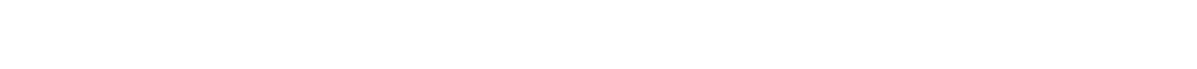

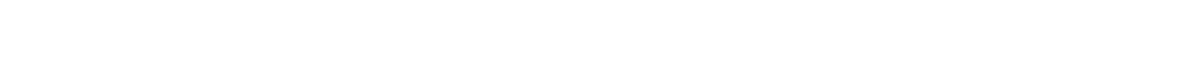

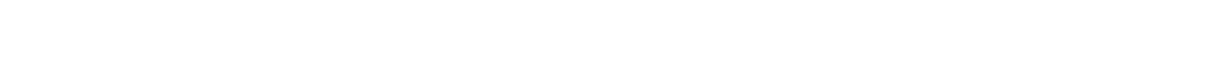

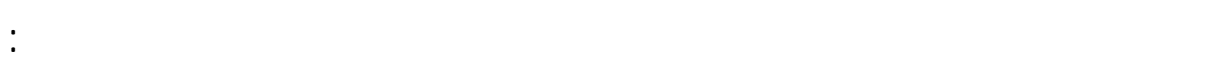
[السط][ (123)

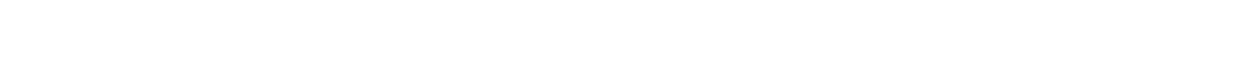

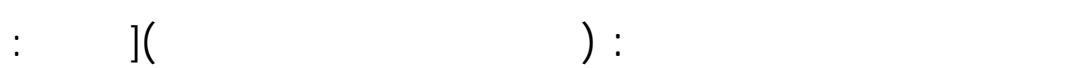

\section{وكفوله: [البسيط]}

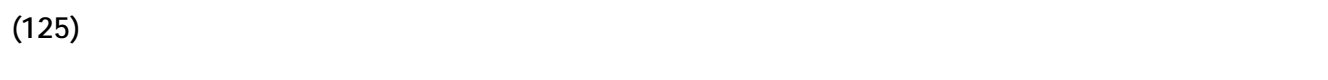

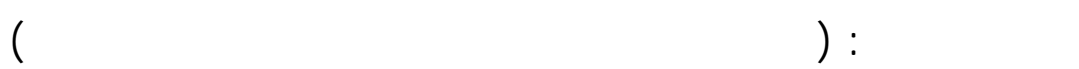
[مريم:4

235/1: بول.

. 231/1 .

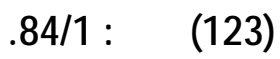

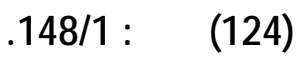

. 


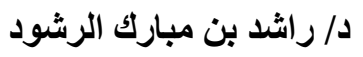

وكفوله: [البسيط][126)

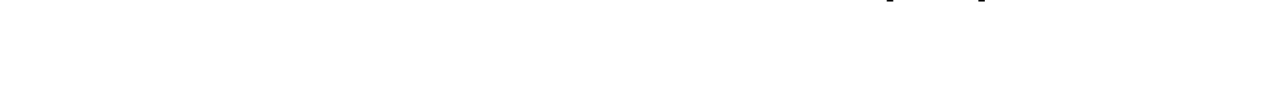

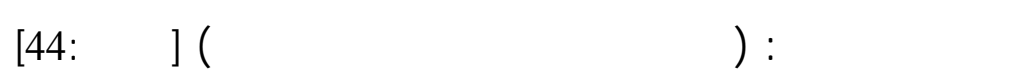

وكفوله : [البسط] (127)

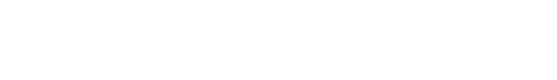

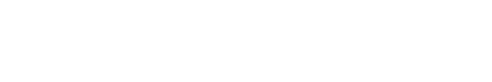

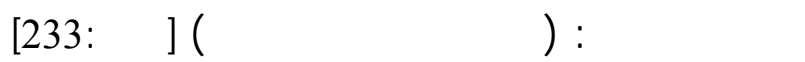 وكفوله:[البسيط]}

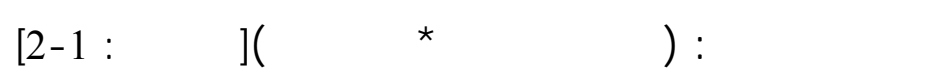

\section{اليو الآخرفيشعره}

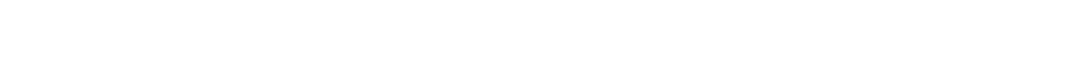

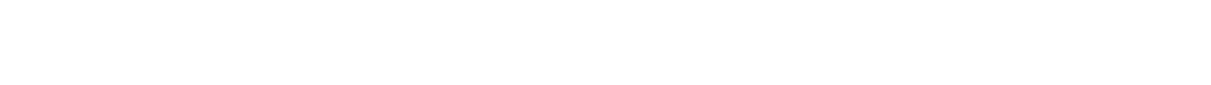

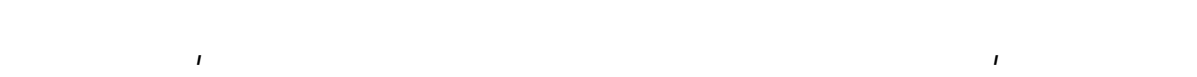

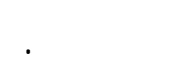
وقد تصور الأخطل هذا الذهول، وهذه الحيرة عنماشرب الخمر، وَعَلَ منها، فلذالك قل: [اطوويل]

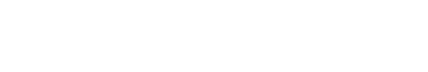

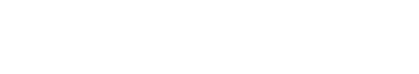

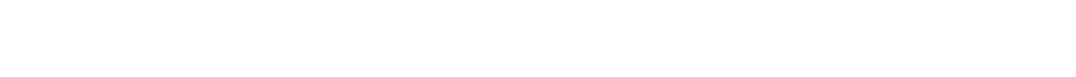

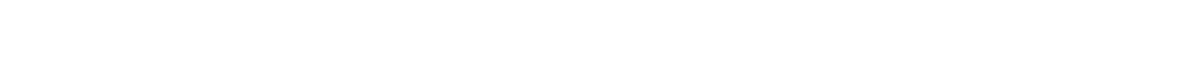

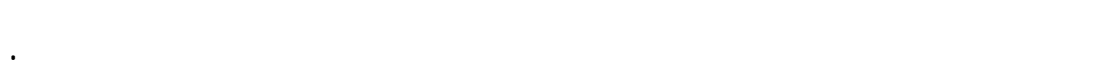

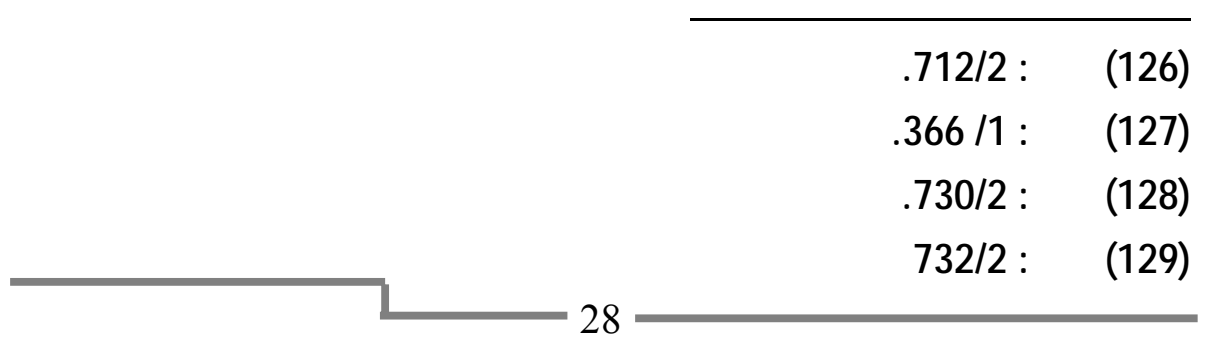


أثر الإسلام في شعر الأخل

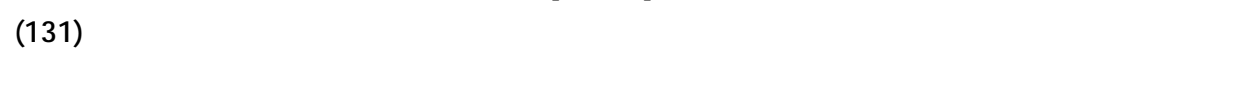

ومن خصائص الجنة كما يبينها البيت - أنها رحمة الـ ورزقه لعب الها،

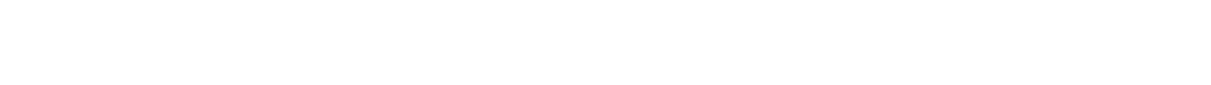

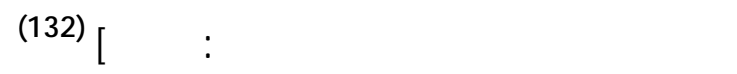

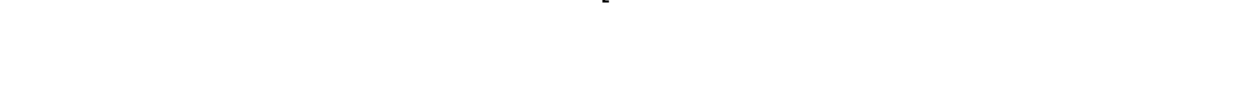

وأما النار فهي لغير المؤمنين، يقول الأخطل : [البسط] (133)

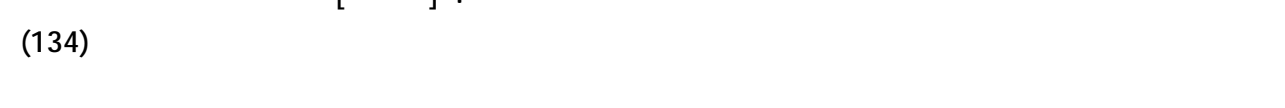

فللشاءر حذر في هذا البيت حيث لم يصرح بأن بني العولم -وهم أع داء

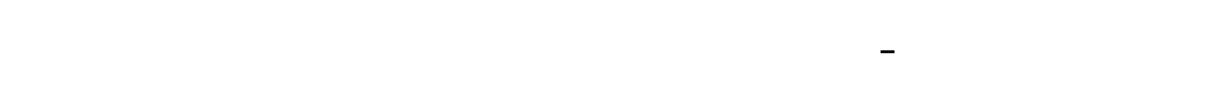

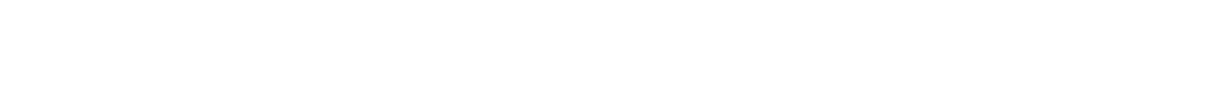

ولوح، واللبيب باللثشارة فينه .

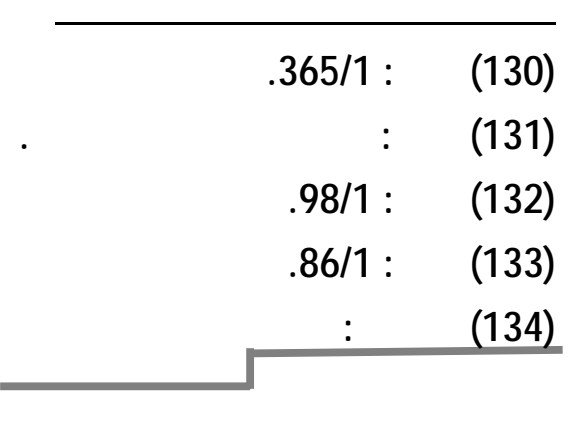




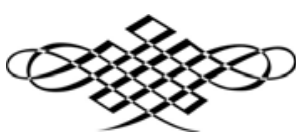

\section{المبحث الثاث}

\section{مo}

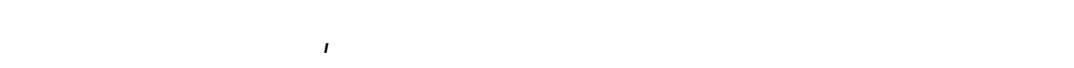

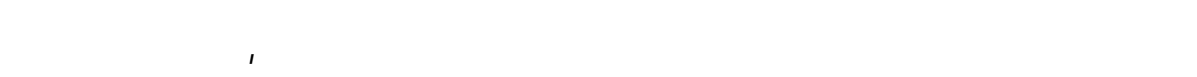

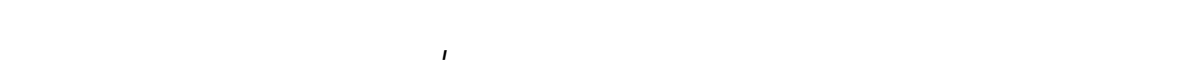

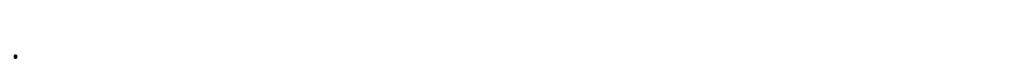

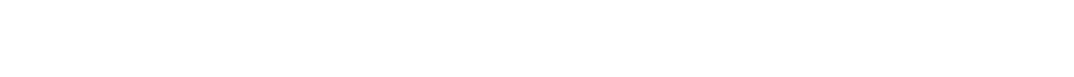

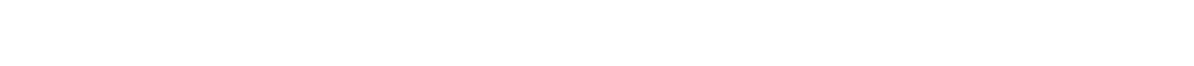

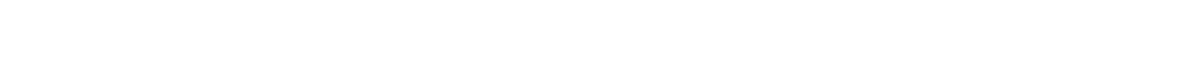

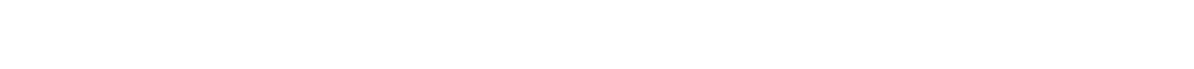

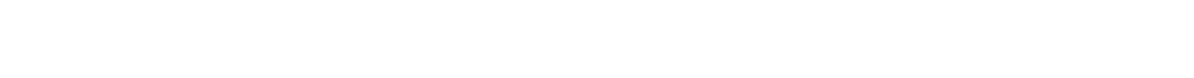

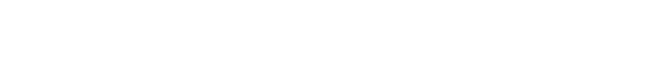

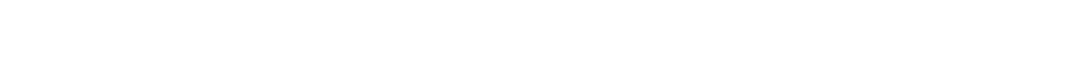

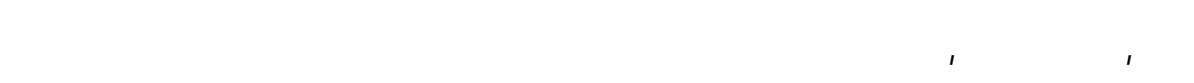
المخل المنلبب لتوضيح هذا المفهوم.

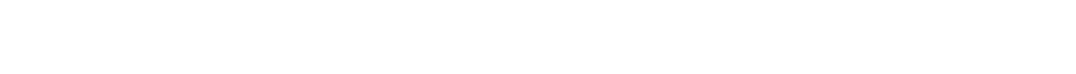

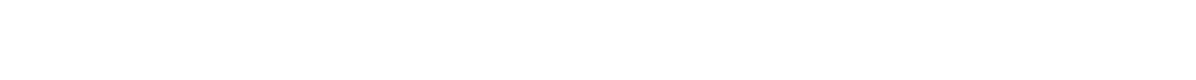

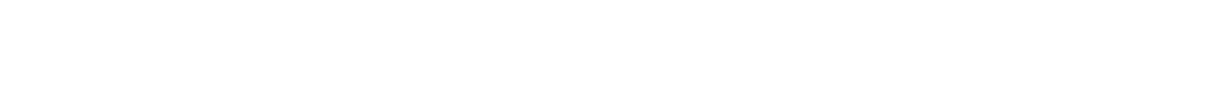




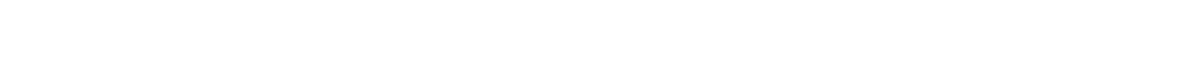

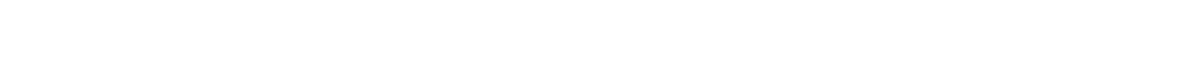

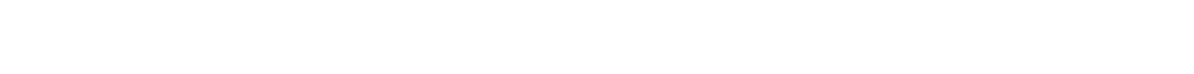

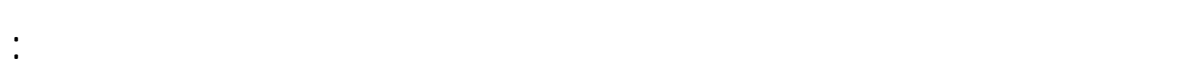
[البسط]

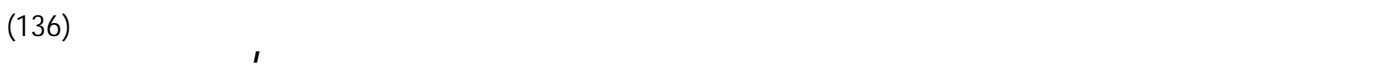
ولاشك أن ثمة ملابست عدية حالت دون تقفيذ مطالبه بطريقة سلمية،

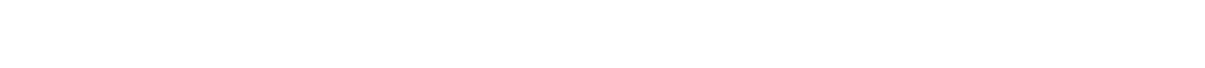

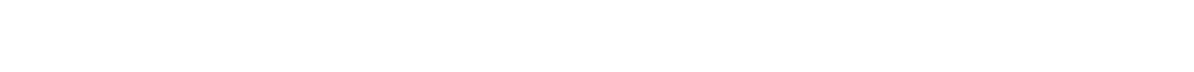

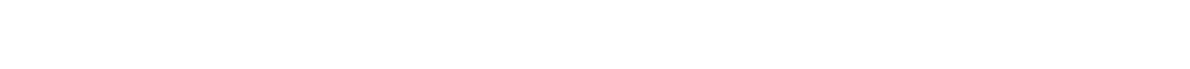

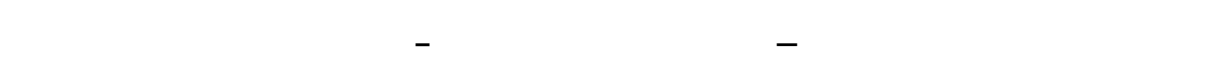

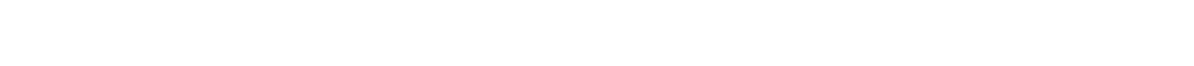

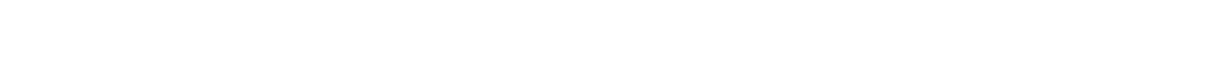

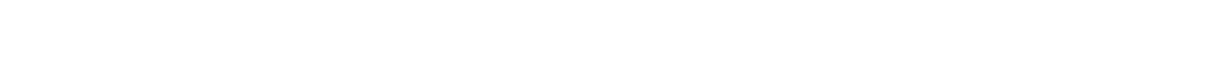

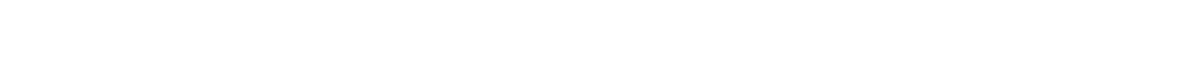

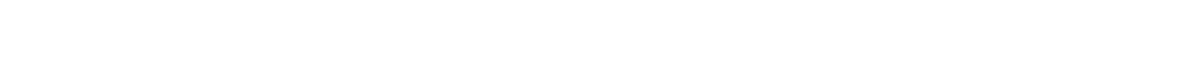
ملخهيا للكل هذه الأحداث والنزاعلت في بيت ولحد: [البسط]

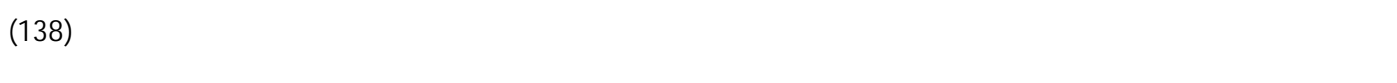
فالأخطل يظطر في هذا البيت إلى الخلافة ظررة مادية بحتة لا أثر للمبسلام

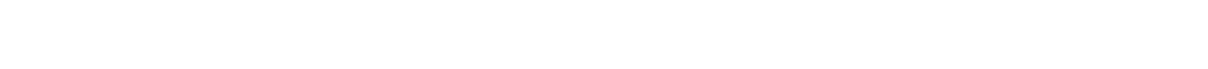

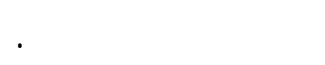

(135) نوانd: 85/1)

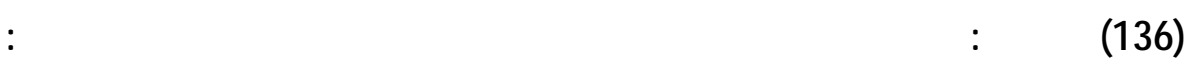
: بوا. (137) نيوله: 85/1)

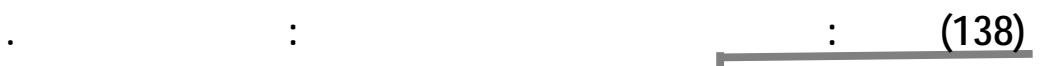
مجلة بحوث كلية الآلب المرولان 


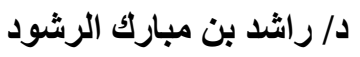

ويؤكد الأططل هذا المعنى في بيت لخر، فيقول:[البسيط] (139)

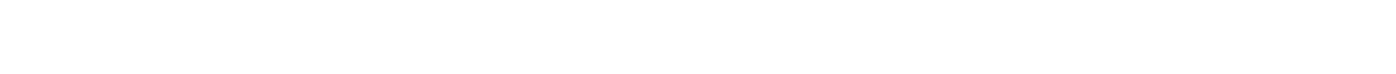

ويخص أبو مالك الأمويين بالخلافة ويرغب بني الحكم فيها، ويذ صحهر

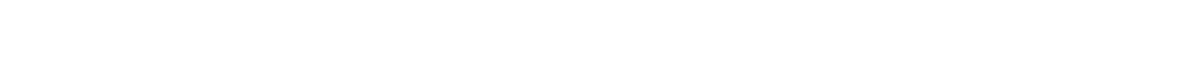

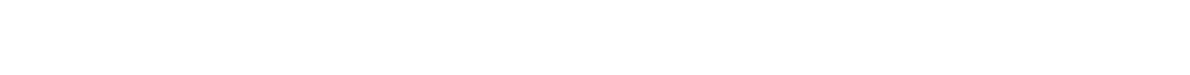

يقول:[البسط]

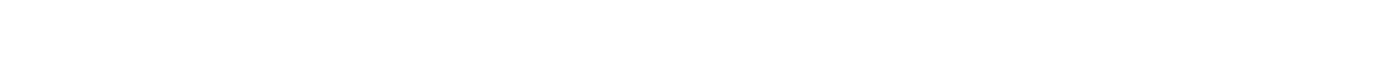

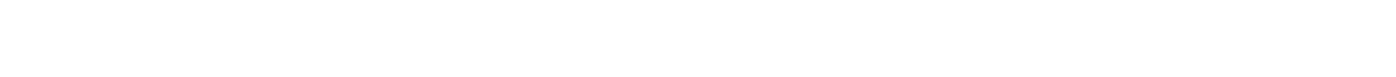
ولذك فقد فضلهم اله، ولختارهم على منسواهم، وجعل الخلافة من حقهم

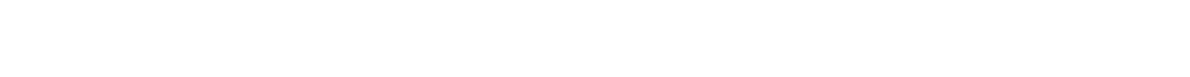

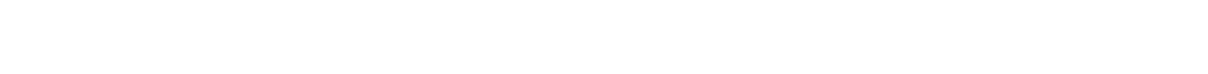
قوله:[الطويل] [141)

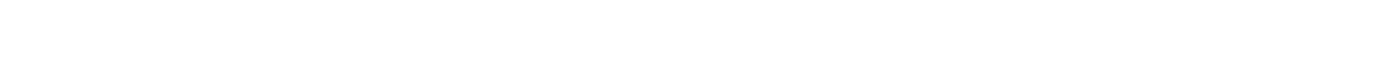

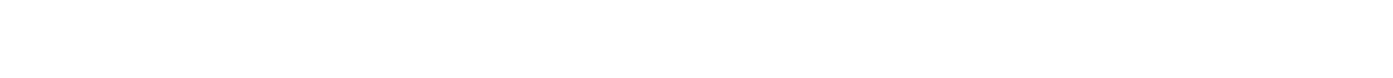
وقوله: [البسيط]

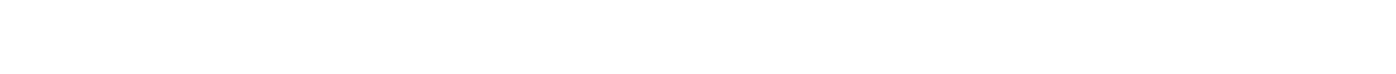
قوله:[البسط]

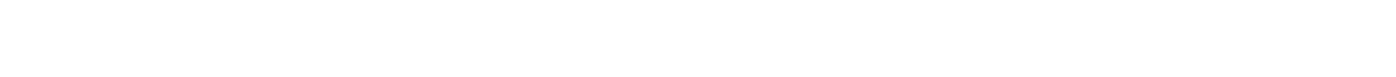

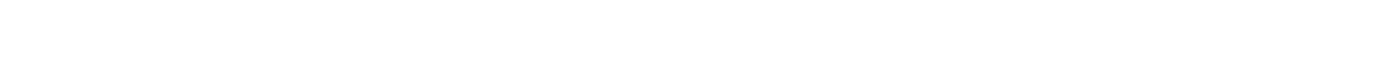
وقوله:[الطويل] (144)

(139) نيوله: 225/1.

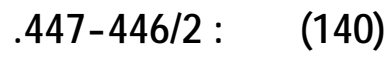

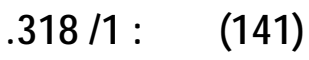

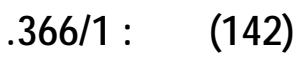

442/2: (143) (142) دوان.

(144) نيوله:

مجلة جوث كلية الآدلب 


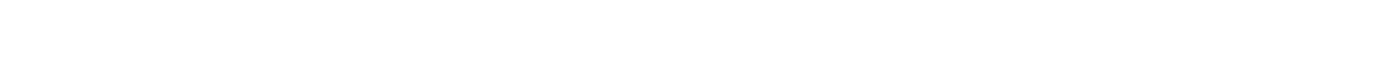

ولعل الأخطل في هذا المعن ينافس المشيعة الذن يزعمون الولاية لعل مي

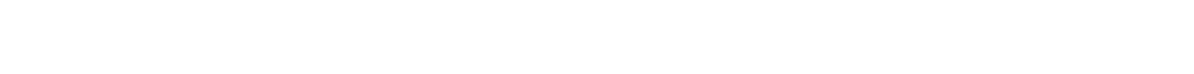

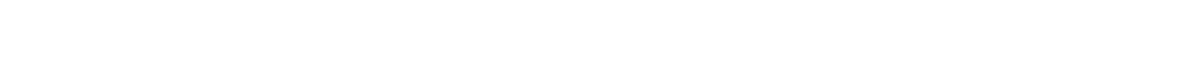

$$
\text { الغيب وغير ذلك . الكان. }
$$

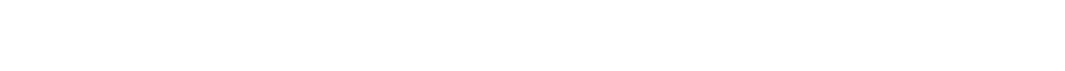

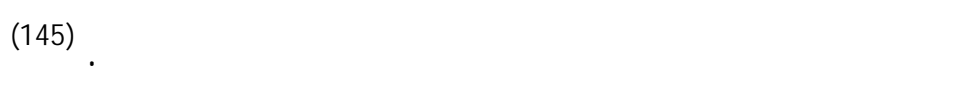

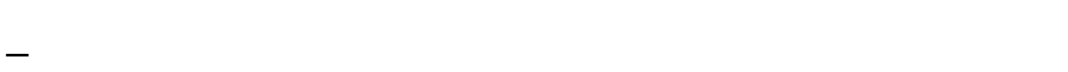

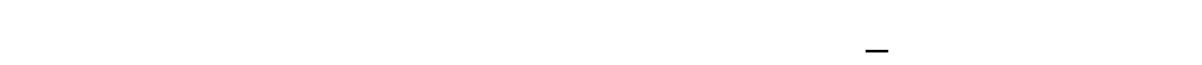

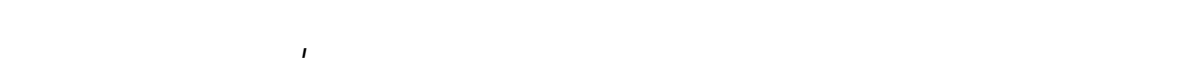

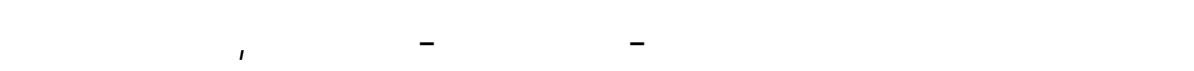

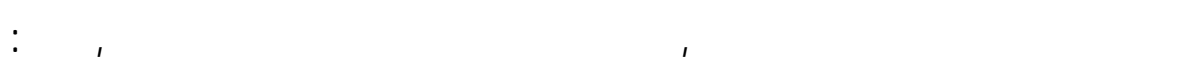

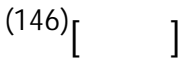

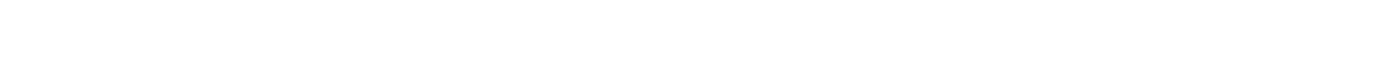

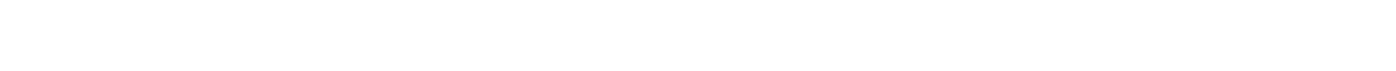
ومن إيشاته به قوله: [البسي]] (147)

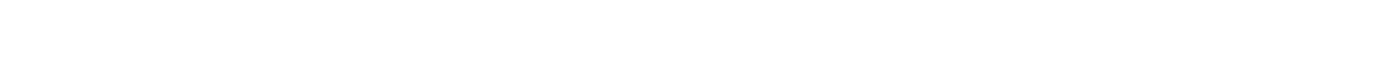
وللثكك إن الظام الوراثي كان معروفًا في الدول اللساقة كدولة الف _سب،

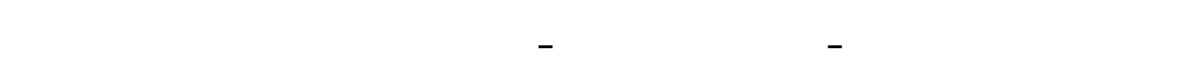

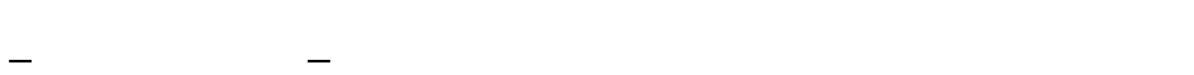

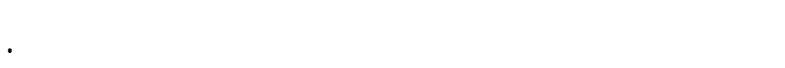

\section{مفلت الحكئ}

بسم الأخطل فيشعره صورةشبه متكلملة للحلكم المثالي من خلال مدحه

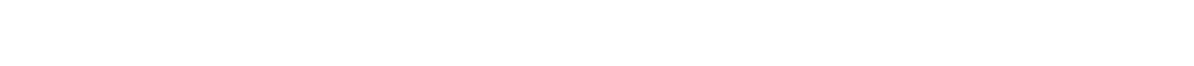

(145)ضف نشق، الصمر الإبلاي: 427.

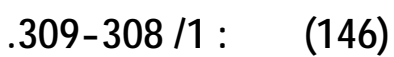

253/1: بوان. 


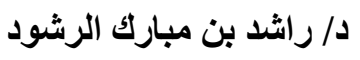

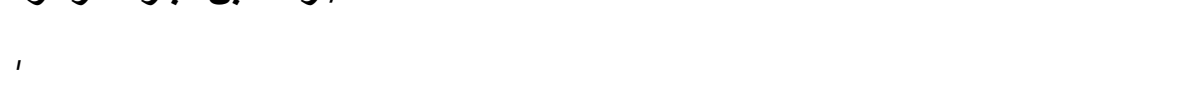

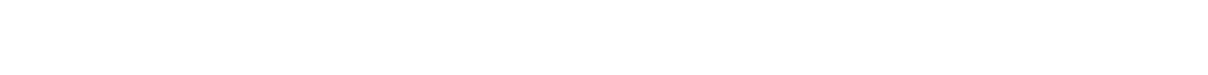

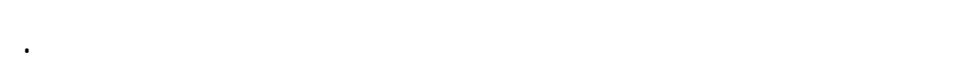

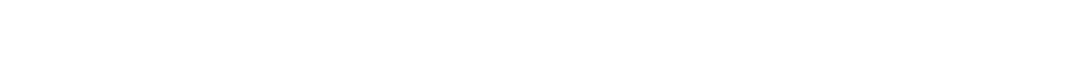

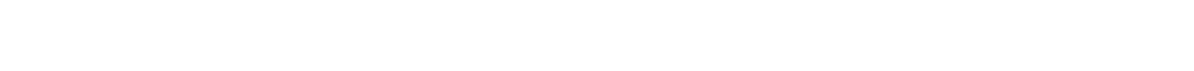

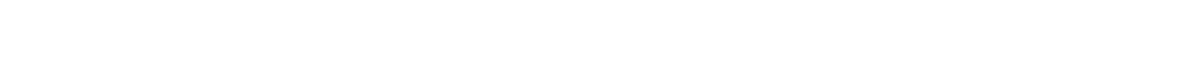

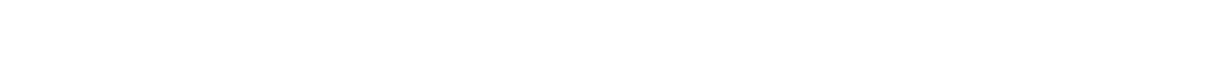

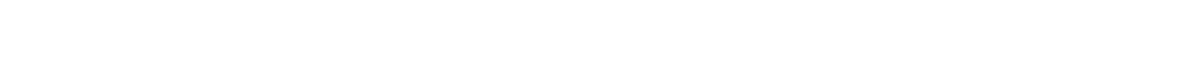

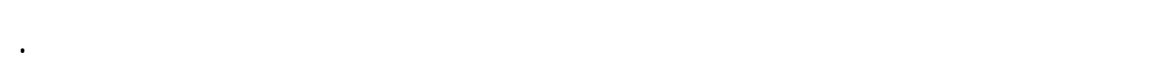

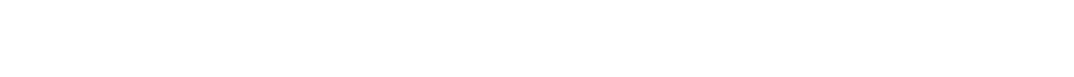

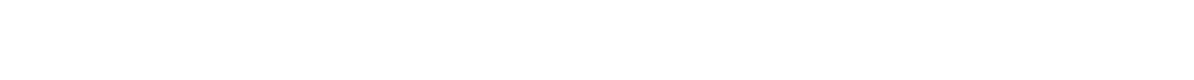

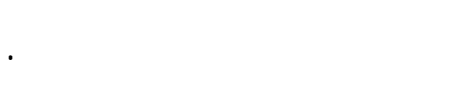

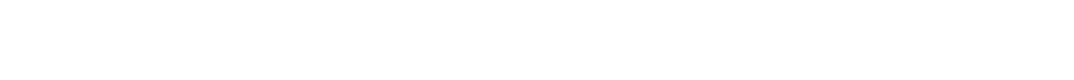

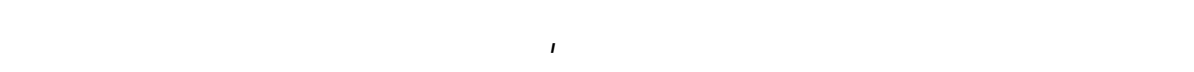

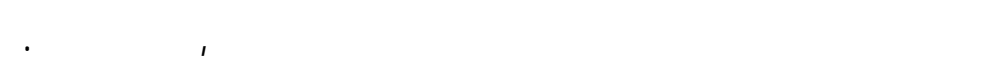

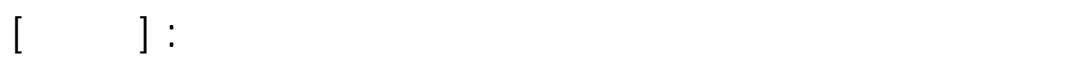

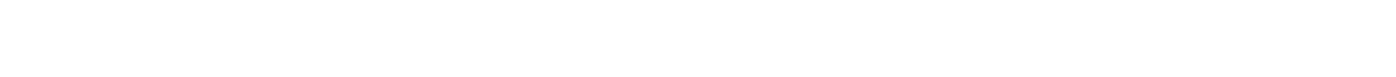

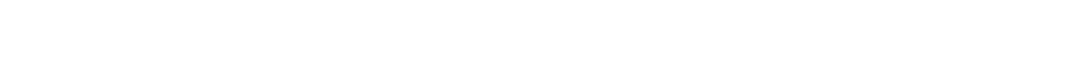

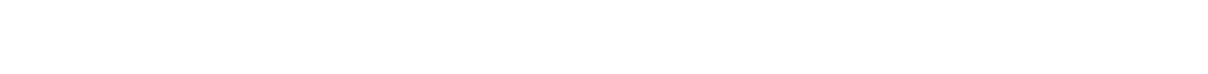

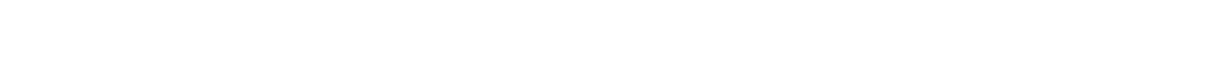
قل:[الطوبل] (149)

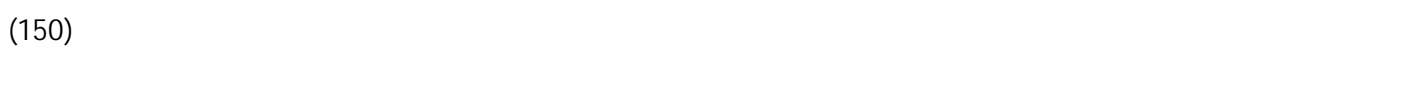

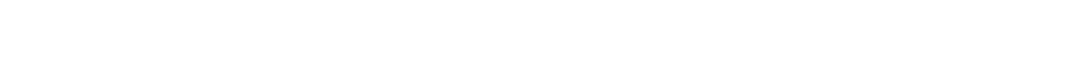

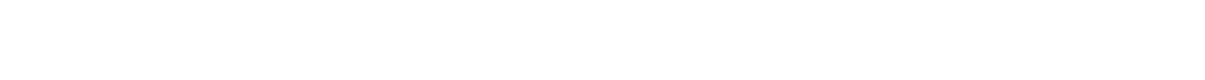

569/2: (148) (149) بوله:

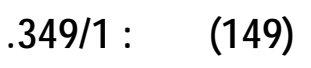

(150) وق الدنيا:زبتها ملرجها: 


$$
\text { أأثر الإسلام في شعر الأخل }
$$

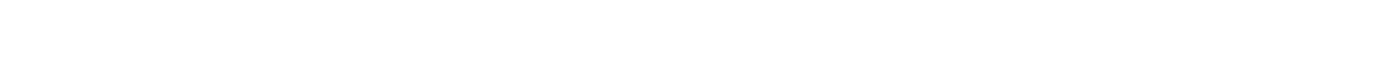
ويقول أيونا: [البسط] (152)

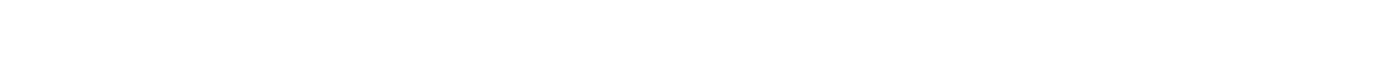

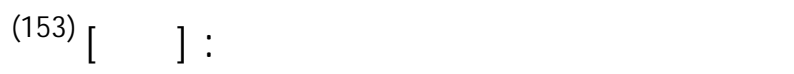

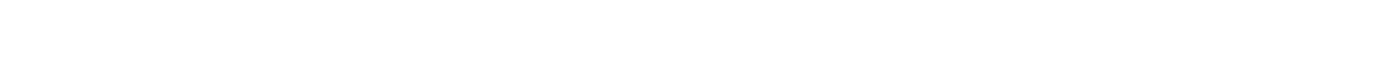
ومن آثارها، التعاون على الحق، والبعد عن الخنا, والصبر على المكاره:

$$
\text { (154) [البطيط] }
$$

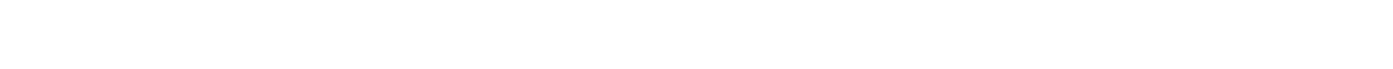
ومن آثارها، كثرة العبادة وللشكر: [الكلمل]

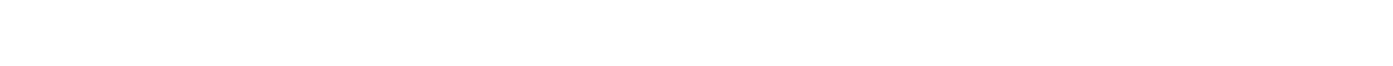
ومن آثارها، عنم بطر النعمة، وخاصة نعمة الملك:[البسط] (156)

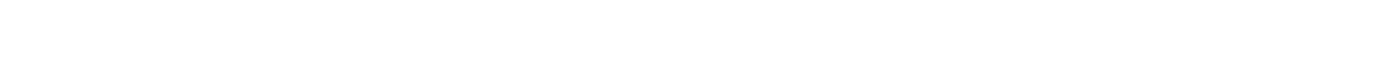
ومن آثارها، الرزالنة وصدق الحيث: [البسط] (157)

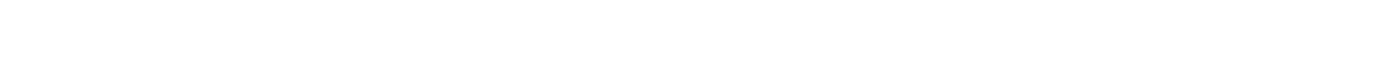
ومن آثارها، العفة والوفاء:[الطويل] (158)

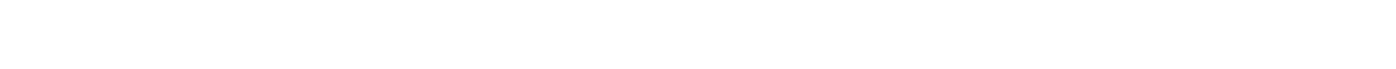
والحققة أن القوى صفةشالملة يمكن أن ينظل في آثارها جميع الصفات

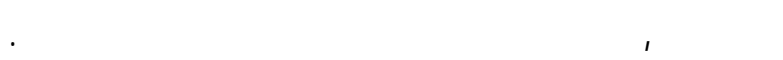

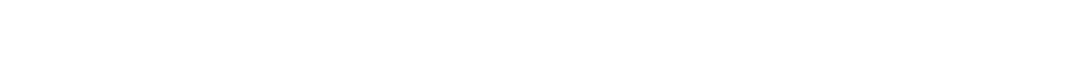

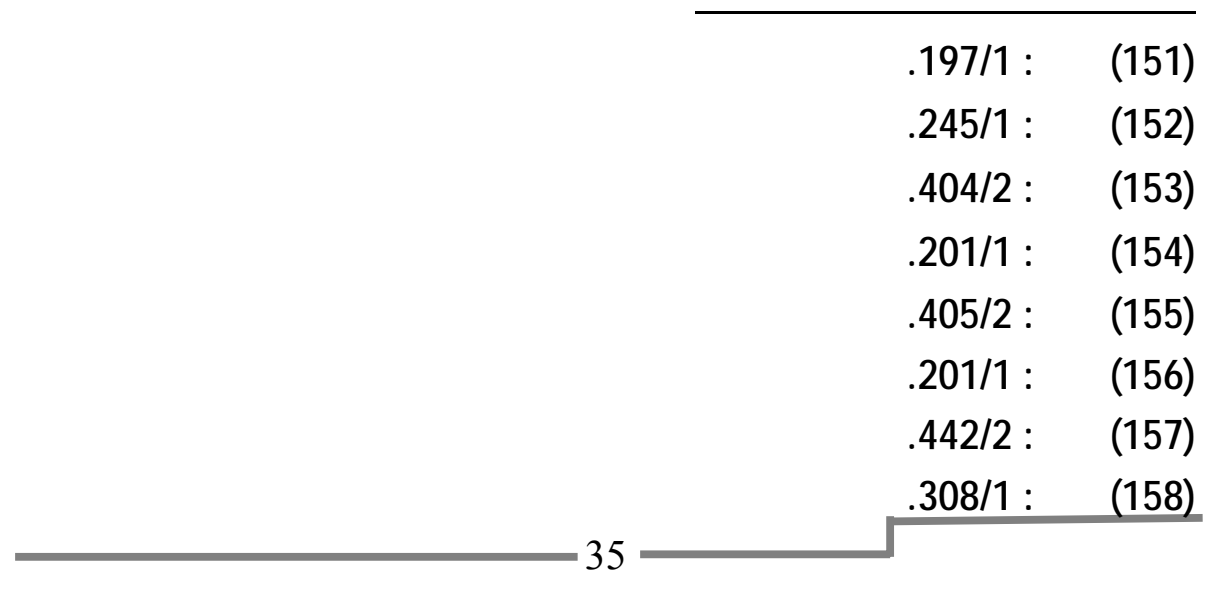




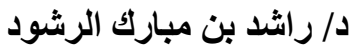

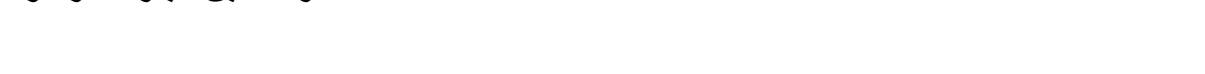

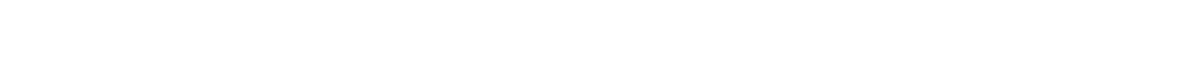

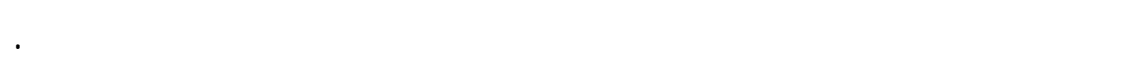

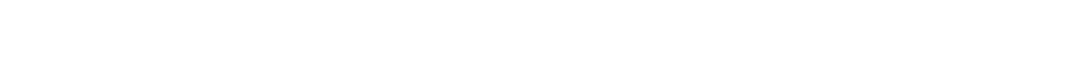

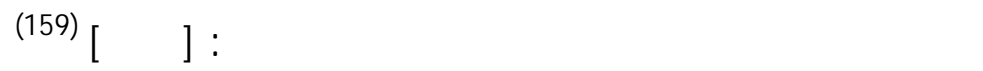

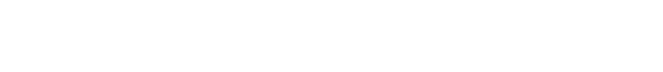

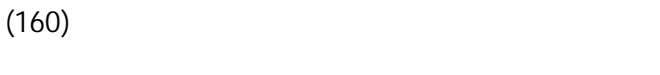
(161)

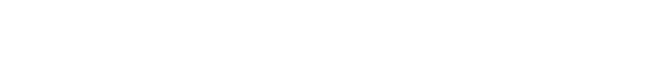

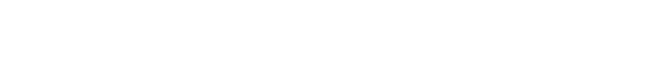

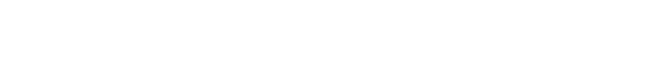

ويقول عنهم :البسط]

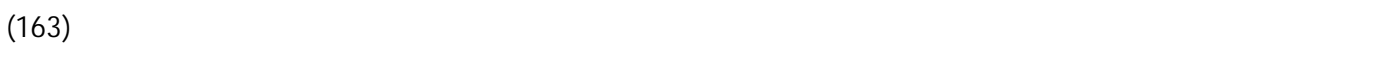
وأبياته في هذا المعن كثيرة, ولكنها تحمل مضمونًا ولهزها، فلذالك لا داعي

$$
\text { للإطالة فيها (164). }
$$

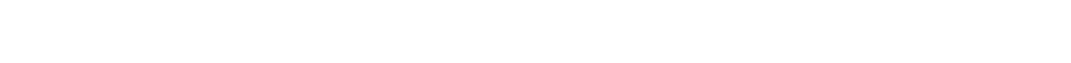

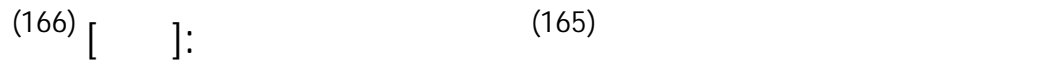

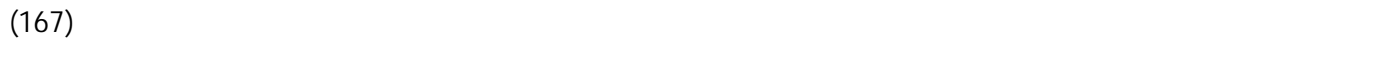

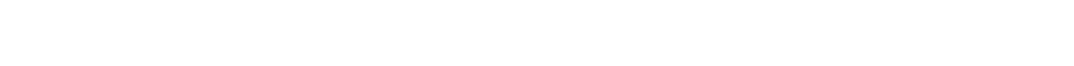

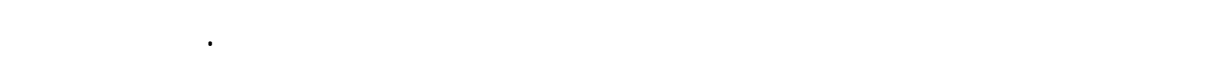

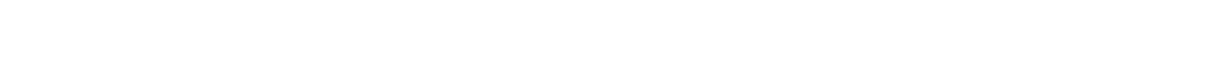

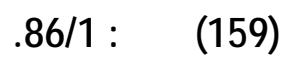

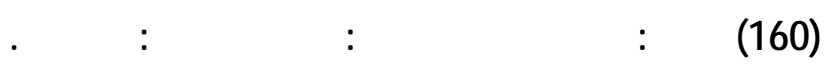

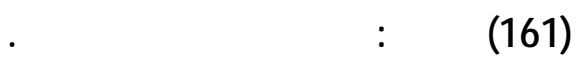

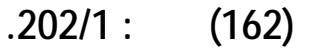

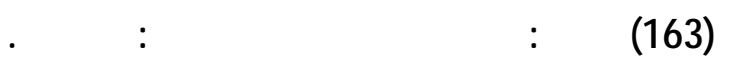

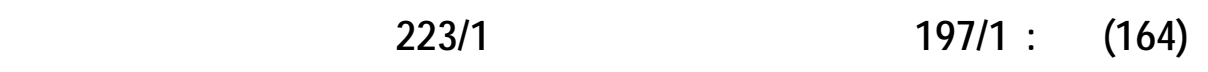

و245/1 \مدح الوليد أيمنا.

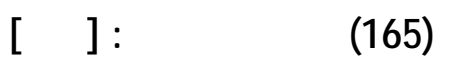

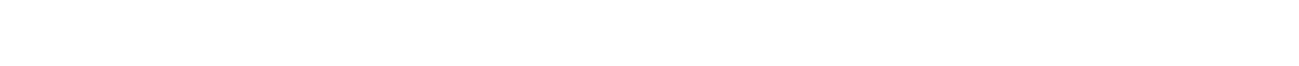

يظار: جرر، ديوله: 89/1.

(166) دوله:271/1)

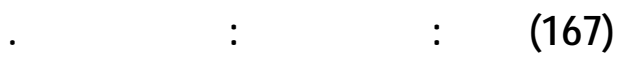




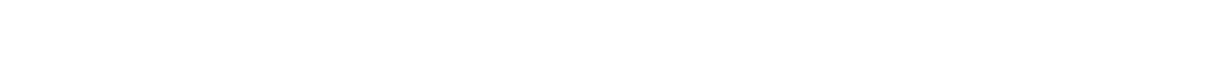

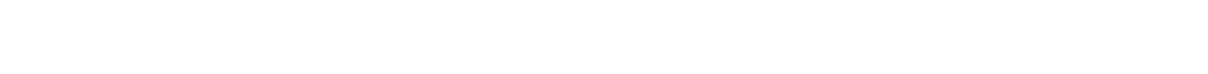

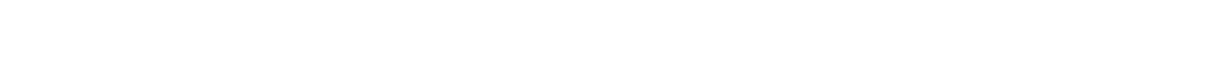

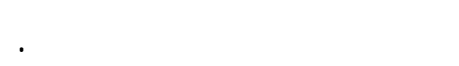
وقد حرص الأنطل على الإثادة بقوة الأموين على هذا النحو ليظهر لمناوئيهم

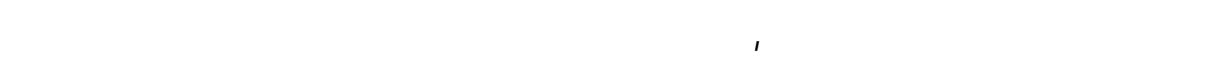
من الأوقت

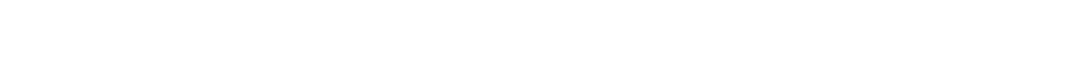

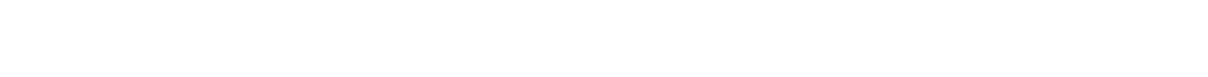

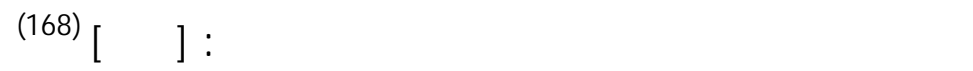

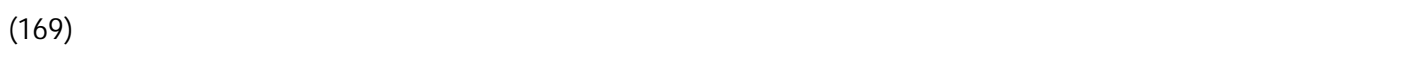
(170) وعنما قل يمدح بشر بن مروان:[الطوبل] (171)

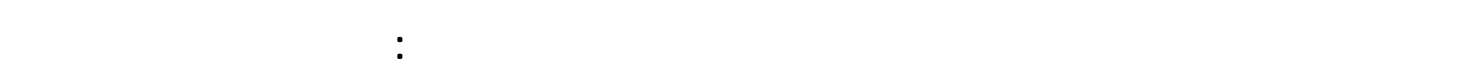

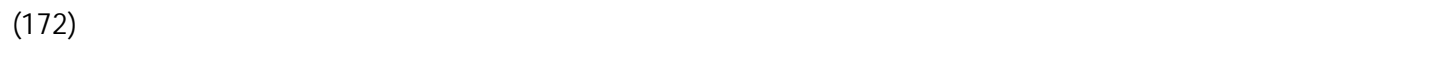
ومما لا ريب فيه أن الحلكم القوي فيشخصيته وهيبته، يـ سلعى لتك يونين

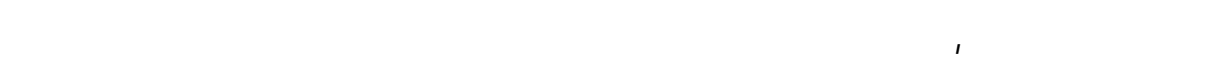
هو يقول عن الخليفة وجيشه :[البسط] (173)

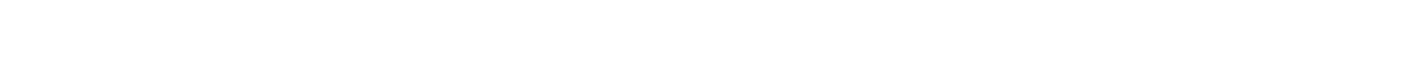
(168) نيوله: 271- 270/1.

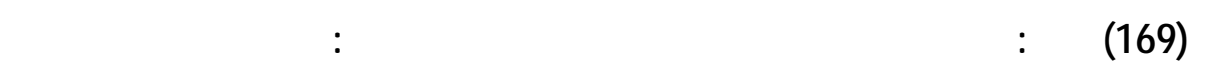
ولزب:شتشند.

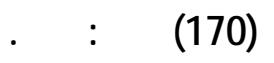
318/1:

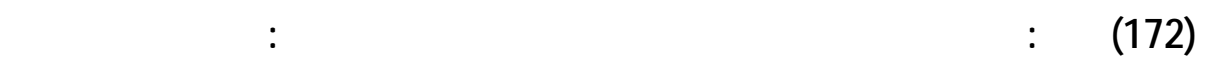
السيد الشجاع:

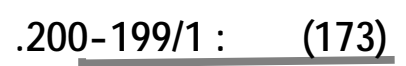
مجلة بحوث كلية الآدب لكيل 


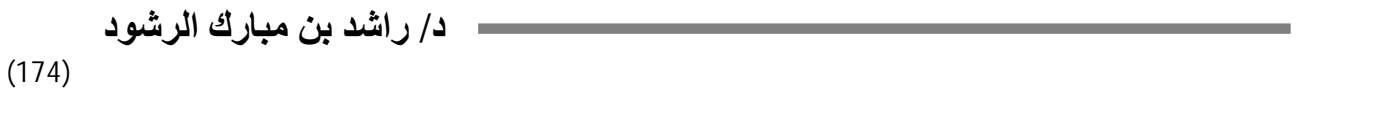

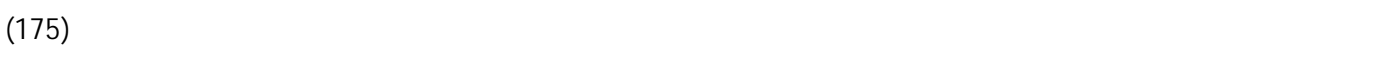

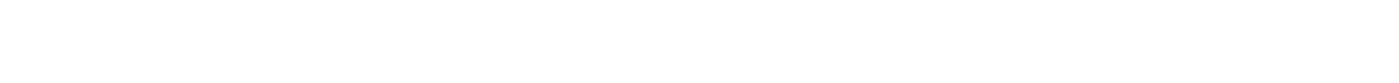

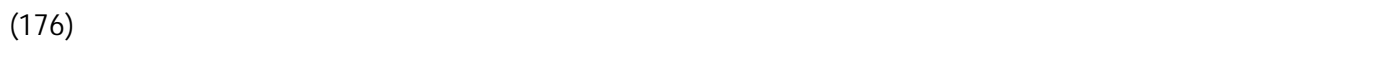

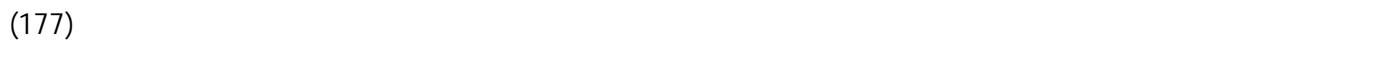
(178)

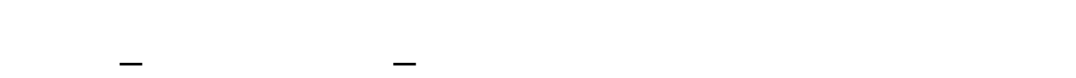

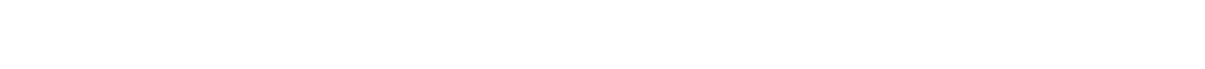

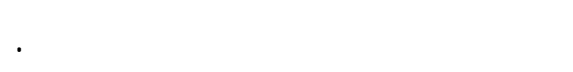

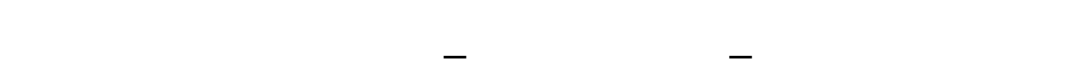

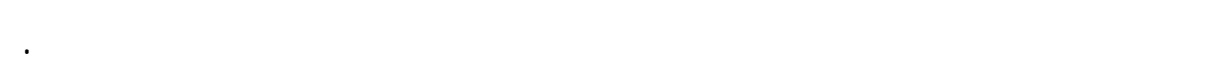

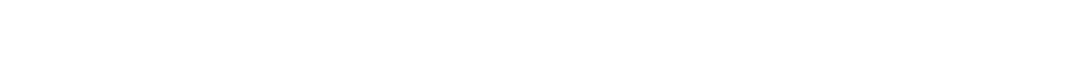

$$
\text { الأخطل:[البسيط] }
$$

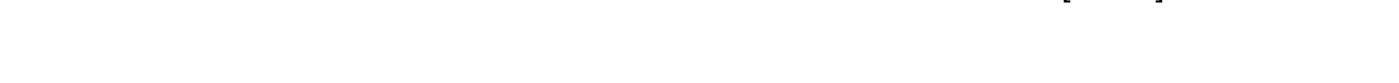
(180) (181)

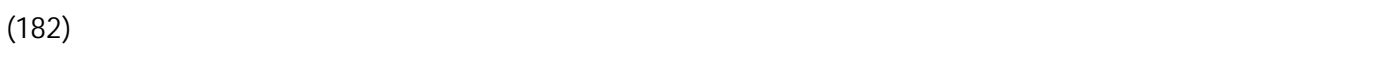

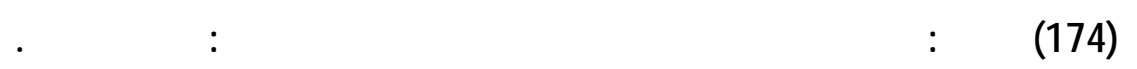

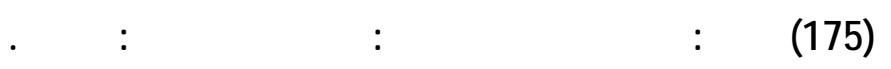

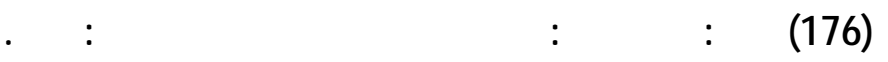

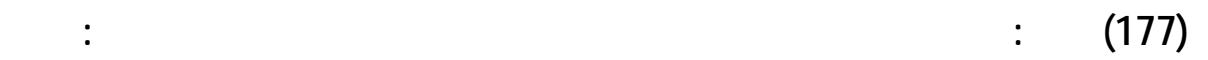

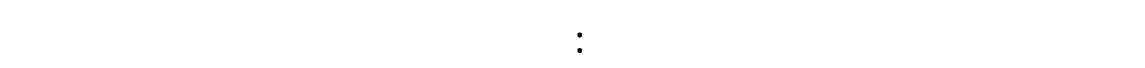

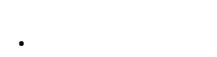

Alling (178)

(179) نيوله: 445/2-446)

(180) (181) الأل: النفن .

(181) التل: الثأر،ولفود: الفلب.

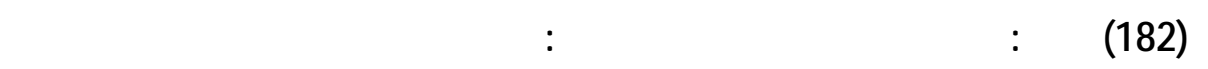

مجلة بحوثكلية الآدلب

البإلب 


\section{وأملم الزبيريين، يقول الاخل الأطل:[البسط] (183)}

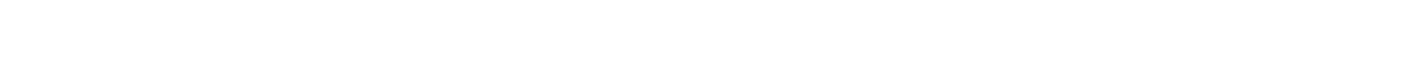
وأمل الخوارج، فيقول ماهظا لبثر بن مروان: [الطويل] (184)

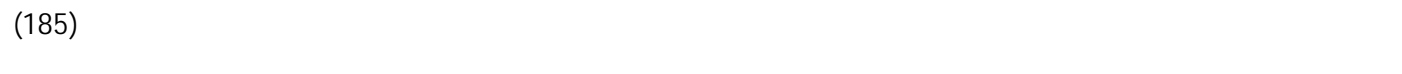

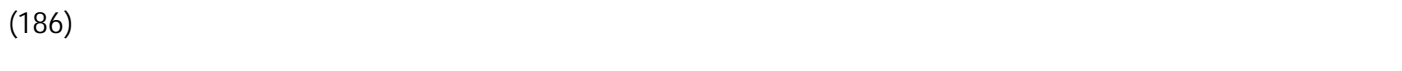

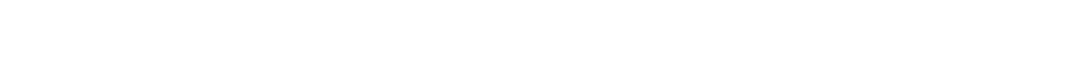

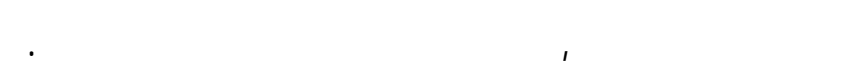

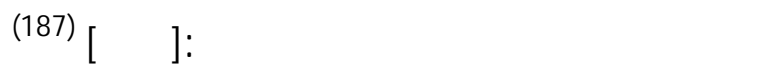

置

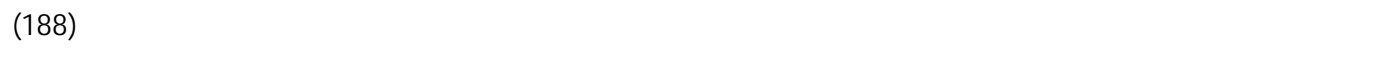

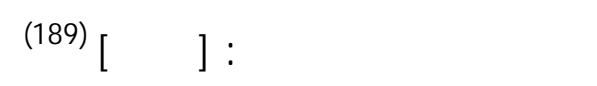

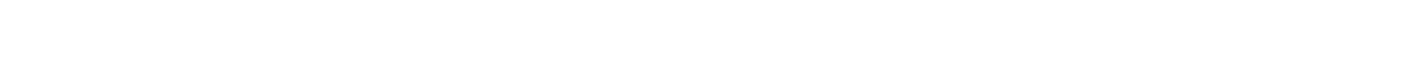

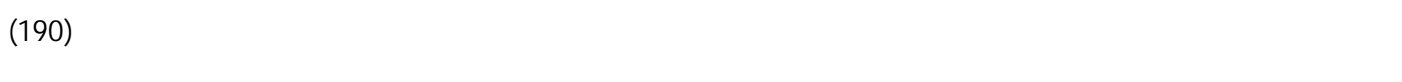

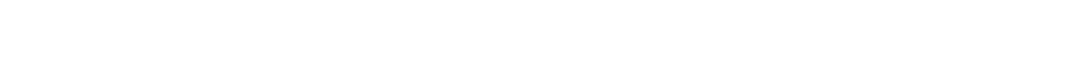

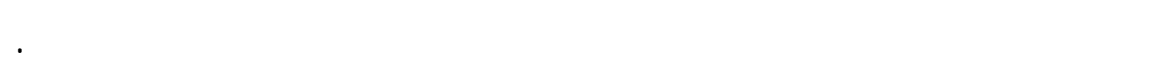

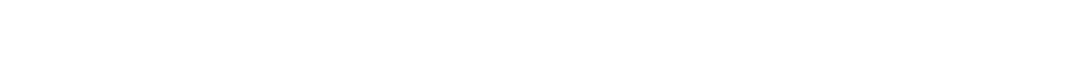

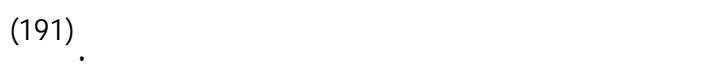

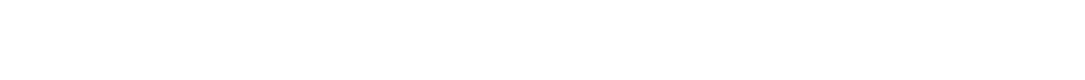

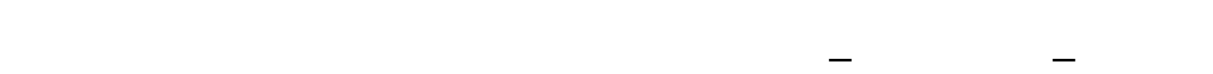

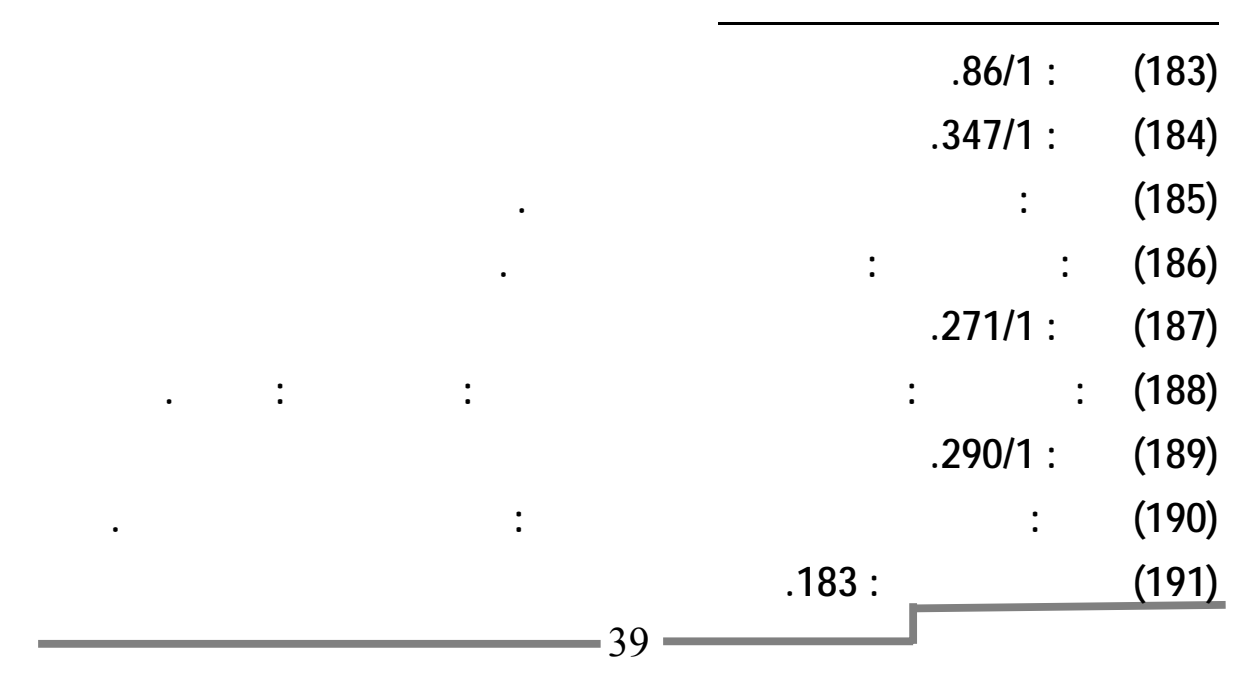




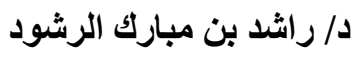

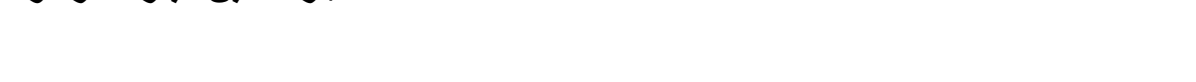

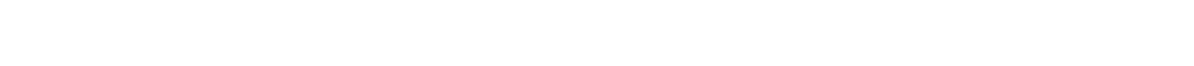
الإسلامي، بسبب هذه الخلافلت (192).

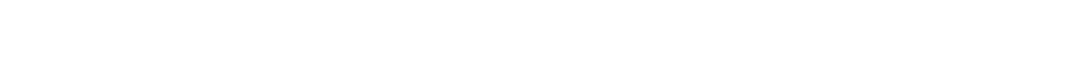

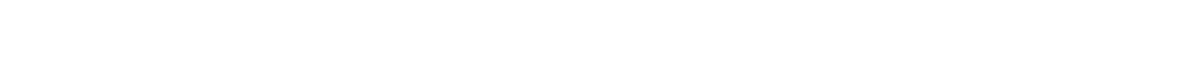

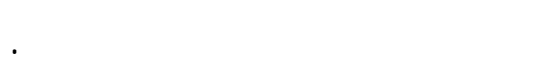

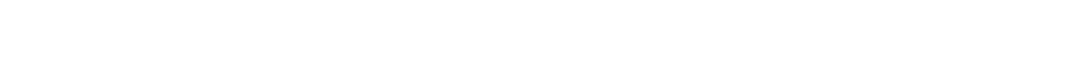

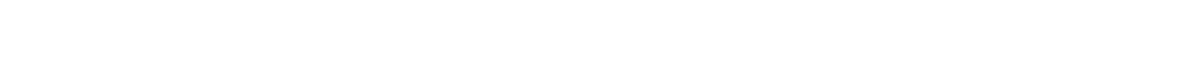

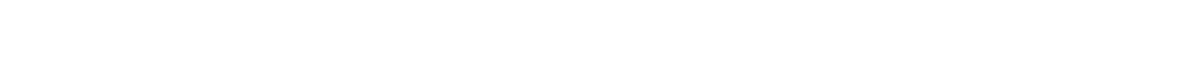

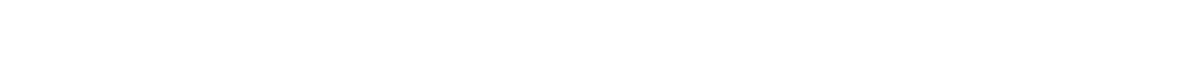
المثالية .

فهو يمتاز بالبياض، كما يقول الأخطل:[الطوبل] (193)

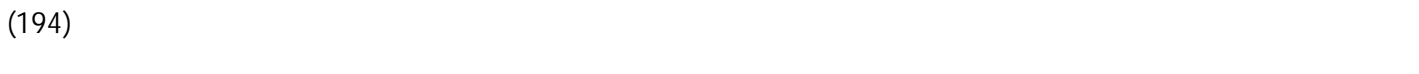
ومع بياضه، فهو يمتاز أيهزا بالوضاءة والوسلمة، يقول الأخطل:[البسط]

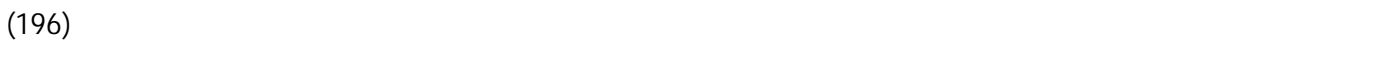
ويقول:[الطويل]

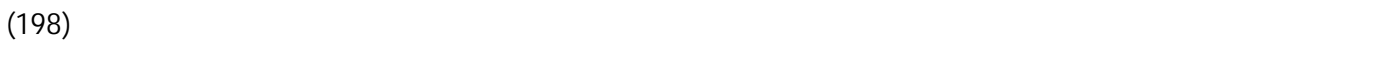

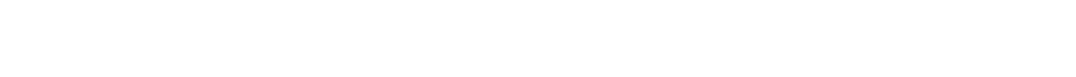

مالك :[الطويل] (199)

(192) يظار، الثهوسنال، المل والنبل: 262/1 -272)

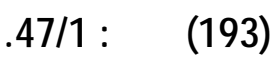

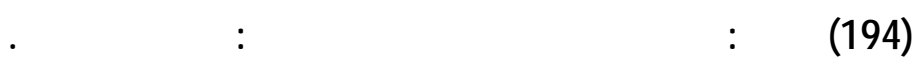
(195) نوله: 508/2)

(196) عنس:رالحالطستة: وجهه.

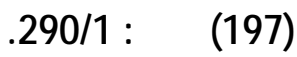

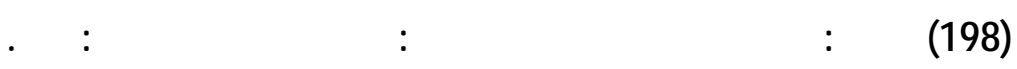

349/1: (199) (198) (لئهن:

مجلة بحوث كلية الآدلب 40 


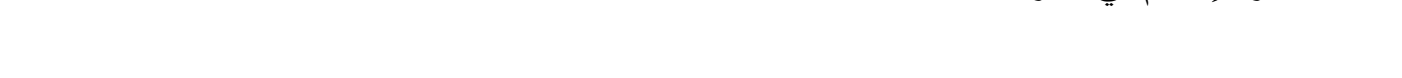

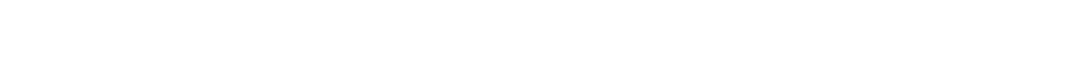

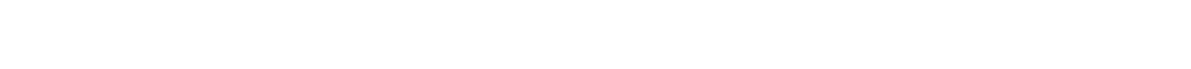

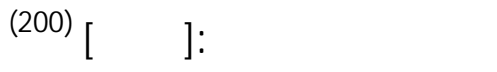

(201) 因 ويقول عن يزيد أيسزا:ا[البسط] (202)

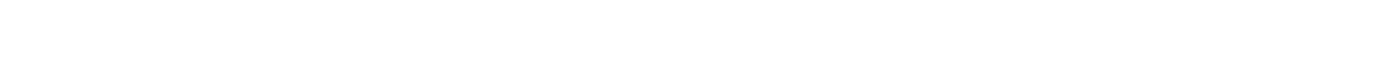
والحلم المثالي في ظار الأخطل يفلى العاني، يقول الأخطل:[البسط] (203)

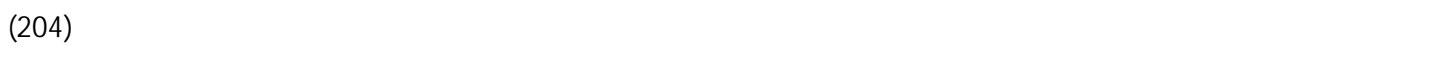

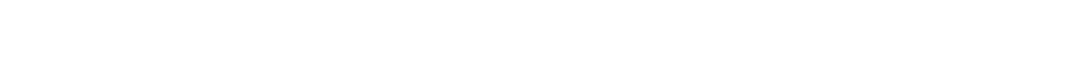

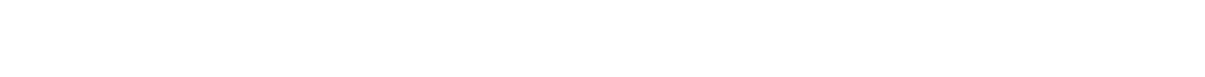

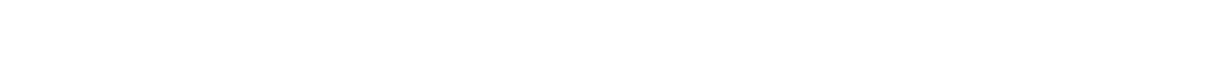

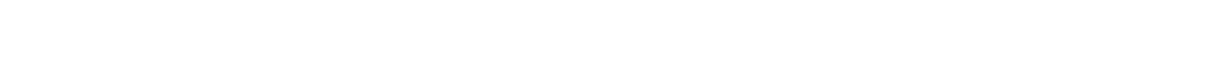

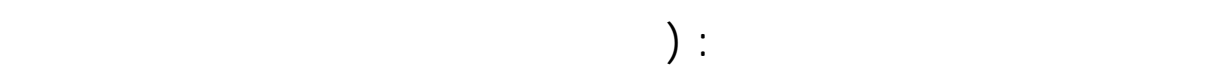

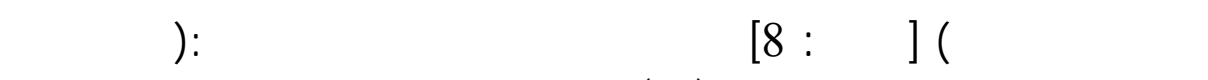

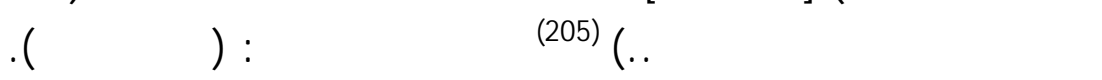

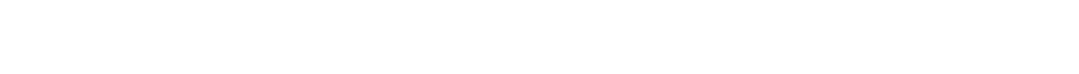
الإسلامي في aفهومه الأموي.

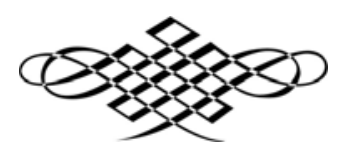

\section{المبحث الرالع}

العبادك البسلمية فيشهره

(200) بوله: 305/1.

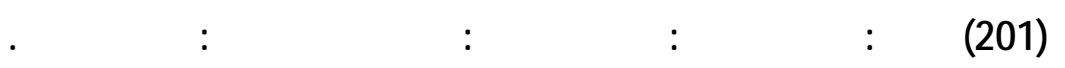

(202) نيوله: 97/1.

(203) نيوله: 444/2.

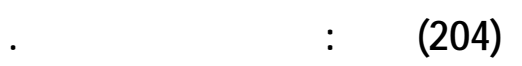

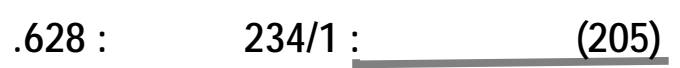




\section{المباكلت الإسلامية فيشعره:}

العبادات الإبلامية كثيرة, ومتنوعة, وشلملة, وقد عرفهاشبخ الإسلام الن

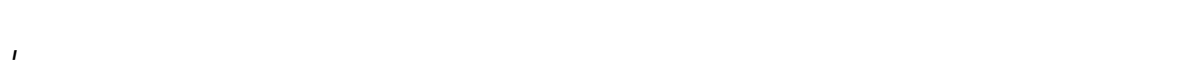
الظاهرة والبطنة. ولم يبخل علينا الأنطل -كعاته - بنكر بعض أنواع العبادات الإسلامية ,

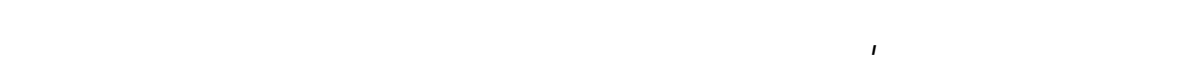

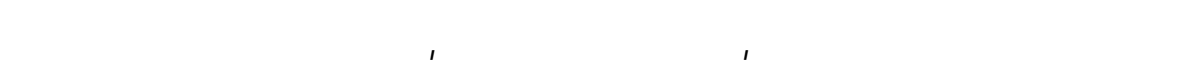

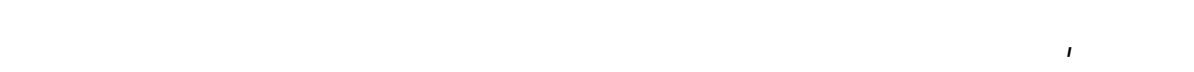

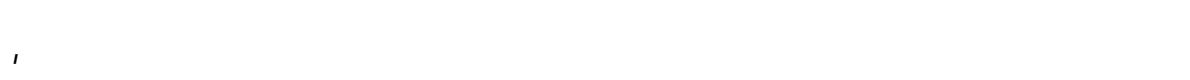
ومنها ما هو خلف عليهم كالصيلم , وبعض الصدقلت وغيرها.

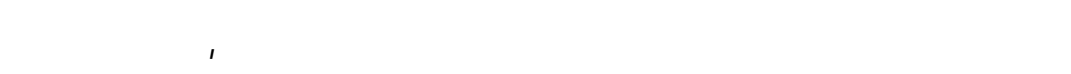

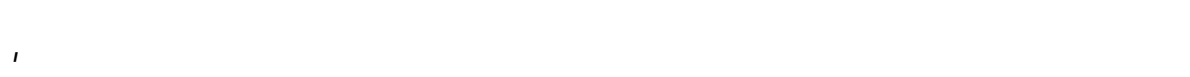

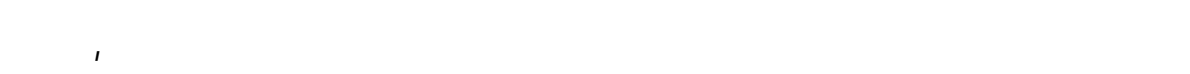
يجتمع المسلمون في المسلجد للصلاة وسماع الخطبة , يقول الأططل:[البسط] (207)

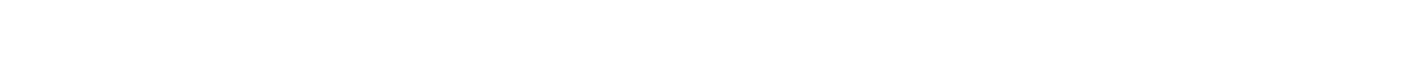
كما أثشار إلى صلاة التهجد وقيلم الليل بقوله: (208)

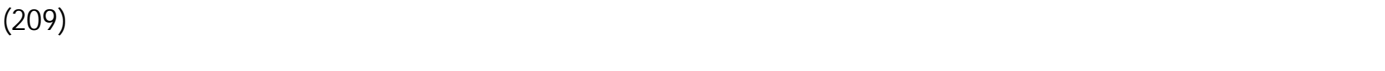
وفي أثناء تأنية هذه الصلوات ,فإن خيار المسلمين وصالحيهم يحرصون

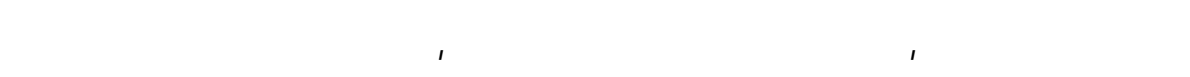

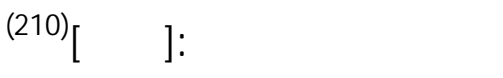

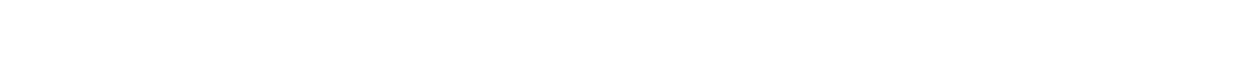

(206) لن تيمة، البونية: 38.

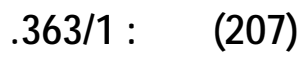

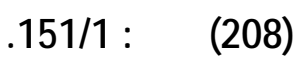

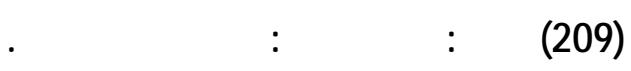

(210) ديوله: 730/2. 


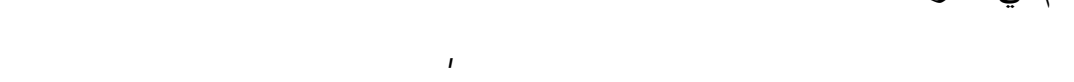
شبه الأخطل الحرباء إذا النتصبت بلجحد هؤلاء: [البسط] (211)

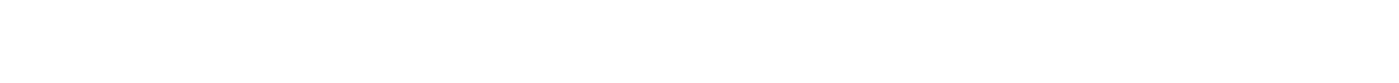
والما كان الحج ركن مهر من أركلن الإسلام , وحدث غير عادي في حيلة المسلمين , كلن لا بدمن وجود صدى له فيشعر الأنطل .

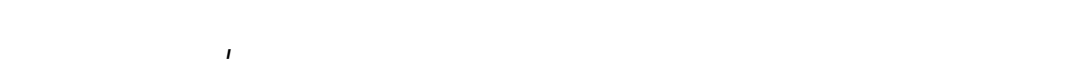

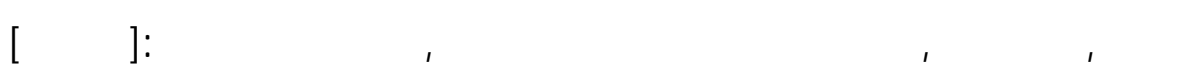

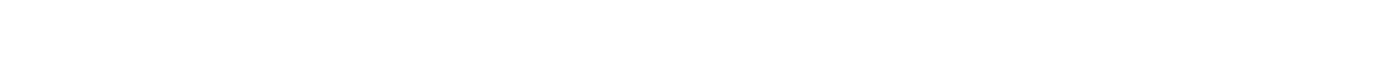 وكفوله:[الطويل]}

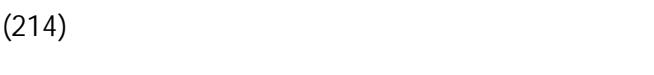

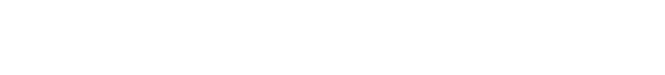

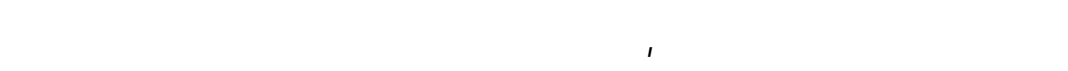
الهدي , فقد أقنم الأخطل بالَ:[البسيط] (215)

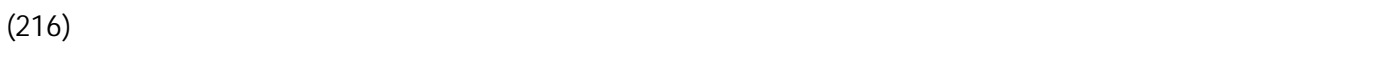

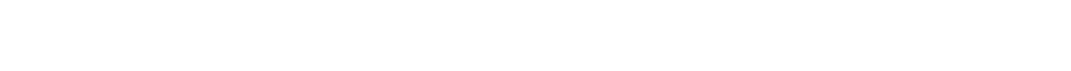

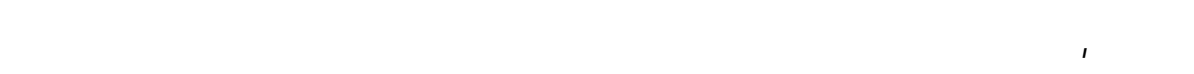
اللجمرات ونح للهدي . اللحن

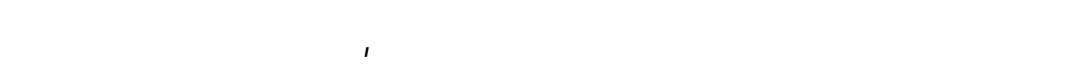

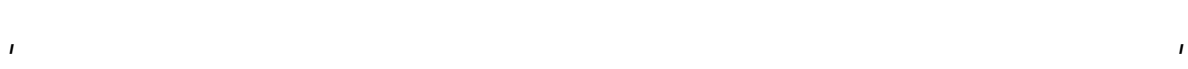
كما يقول أبومالك:[البسط] (217)

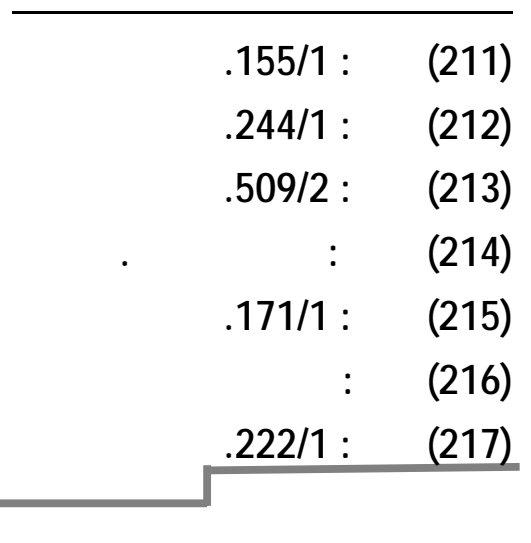


د/ راثد بن مبارك الرشود

国 ويقول:[البسيط]

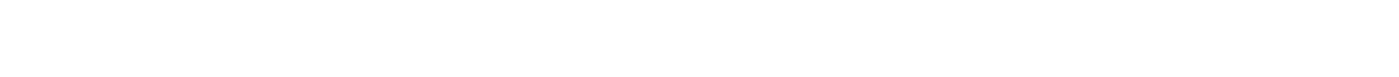
ويقول أيهزيا:[الوافر]]

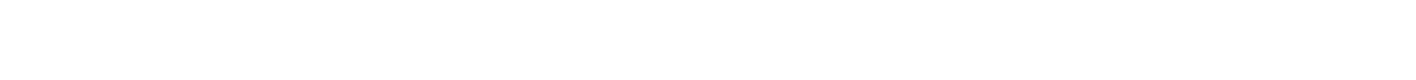
ومن الأمور التي حثّ الإبسلام عليها التوبة, وقد أشار إليها الأخطل ف في بيت ولحد , حيث قل: [الطويل] (220)

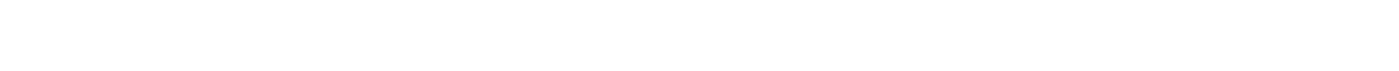

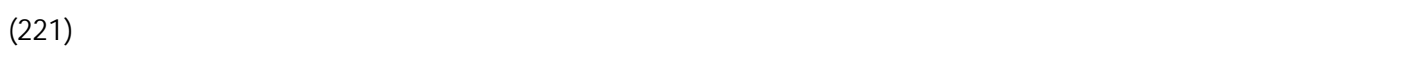
ونلانظ أنه في هذا البيت يدرك أن التوبةسبب في محو الذنوب ومغرتتها

هذه مجمل العبادات الني لُٔشار إليها الأخطل , وفي مقابلها فقد أششار إل ه. المعاصي ودواعيها , وجملة منها .

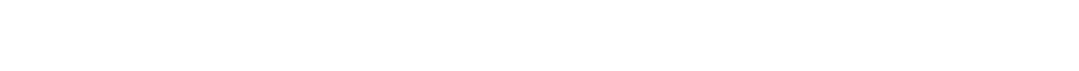
كما يقول الأخطل:[البسيط]

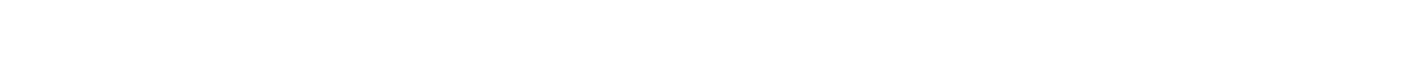

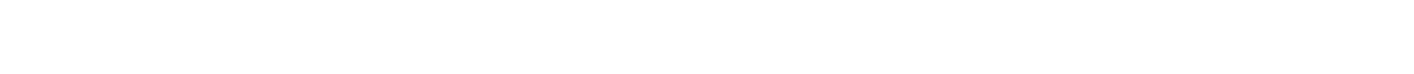
كما أن الخلوة والافراد قد تعين الفس عل ف الوق -وع ف في المطظ ـور. قيقول:[الكلة]

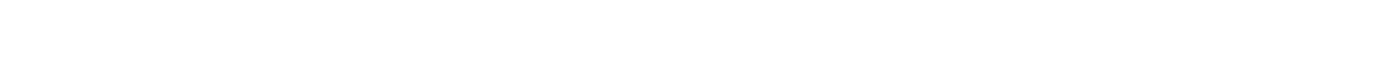




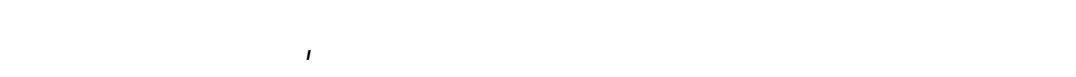

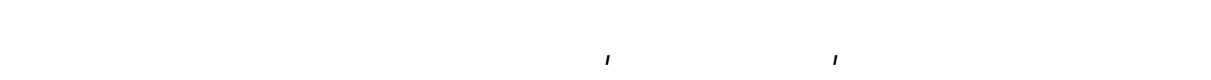
الأخطل في وصف بعض الفتيك عنما يراهن هؤلاء: [البسط] (224)

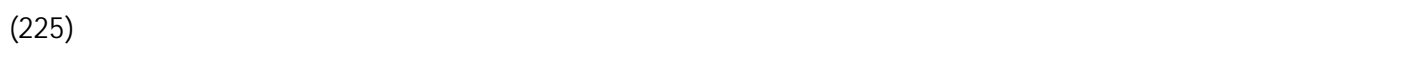
ومن المعاصي الكبار الني أشار إليها الأططل: الفاق وقد رهم هذه الكرة

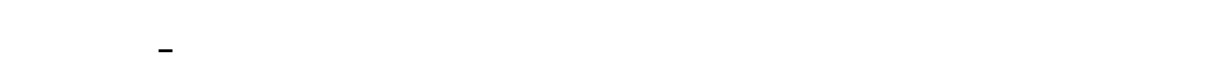

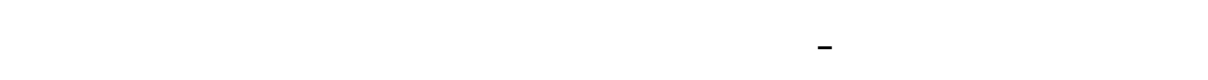

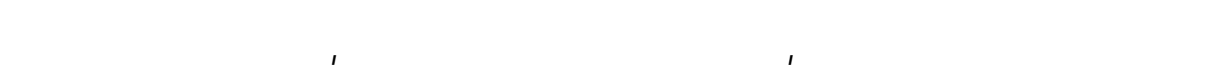
قيس:[الطوبل] [226)

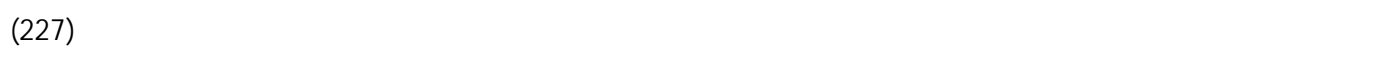
(228) كما يقول عن بني لسٔد: [الطويل] (229)

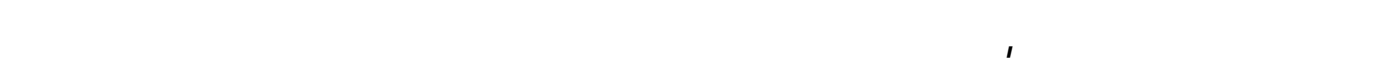

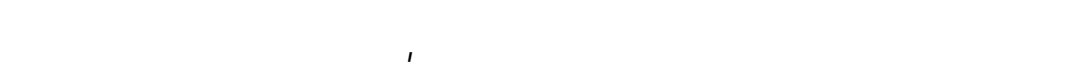

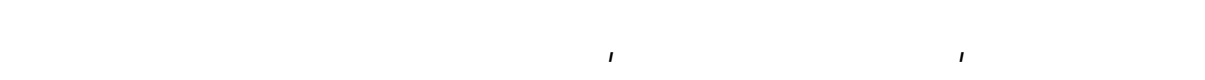
لخنجر الأسدي:[الطوبل] (230)

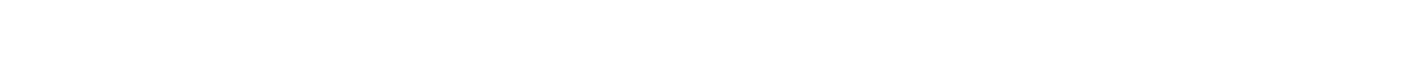

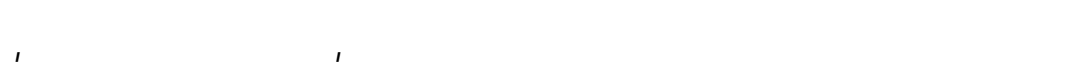

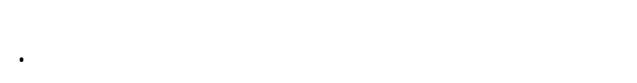

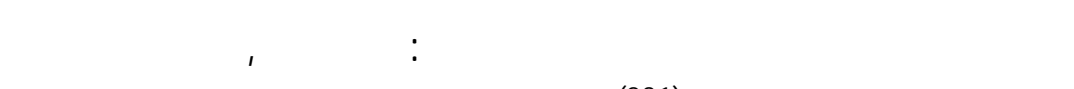
كليب بن يربوع قوم جرير: [البسط] (231)

604/2: 224) بوله

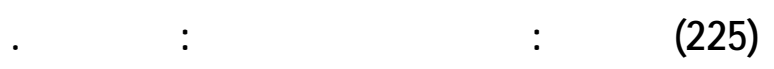

(226) بوله: 189/1.

(227) وهلت: خه

(228) الهمر: الل والضوع.

(230) نيواله: 459/2.

(230) ندوله: 464/2.

209/1: 231 (230) نول. 
د/ داشد بن مبارك الرشود

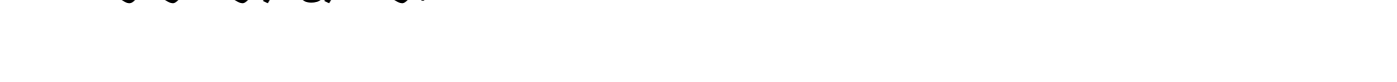

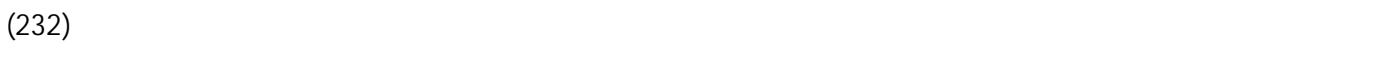

قفي أن أقول: إن هنك أبياتاً تنسب للأخطل هي:[الوالفر] (233)

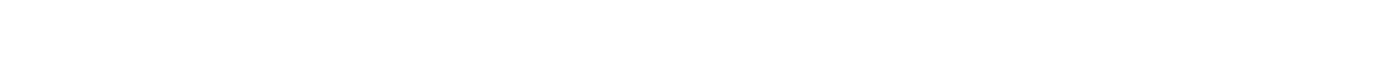

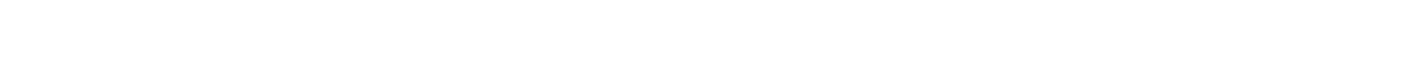

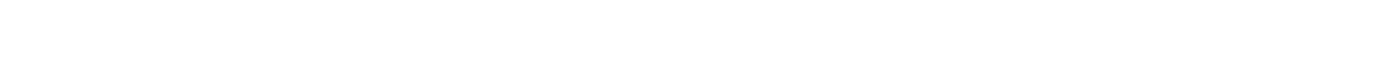

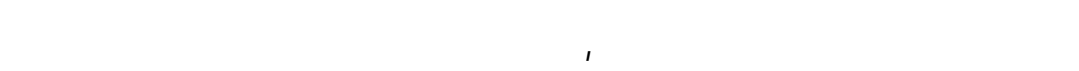

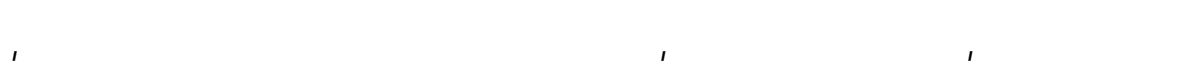

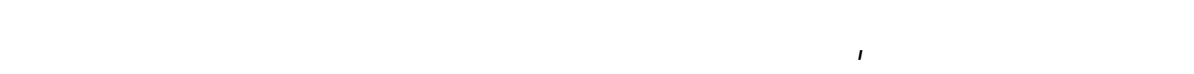
أشثعاره , وأطقة تأثره به كثيرأمن أبياته .

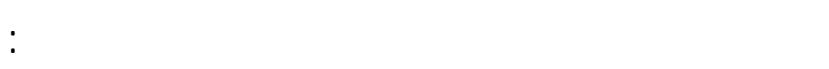

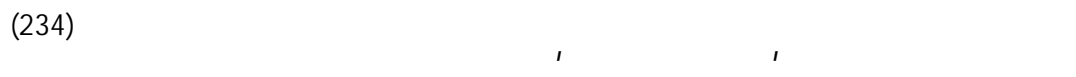

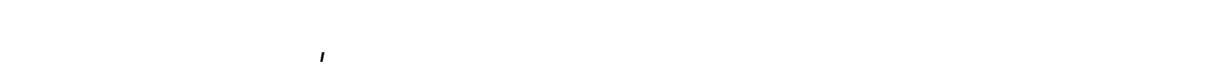

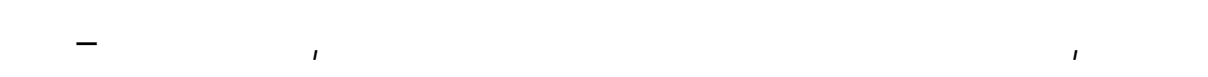

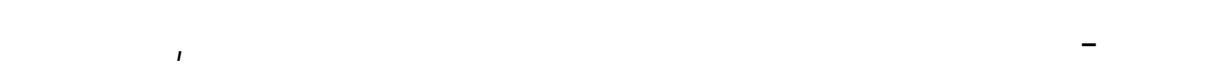
الافتراض الأول غير صحبح , فإن الأططل قالها فيما يبدو وهو مخمور فلا يعت الهب 2 قوله , ولا يحلسب عليه. أو أنه قالها في أول التصاله بالمسلمن في فترةشبابه, قبل ترسخ مبادئ

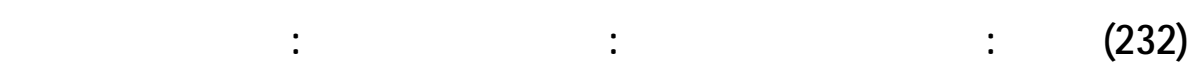
مضلة الأمساء الآ بالملكة للربة السموية. 755/2: 233) (234)

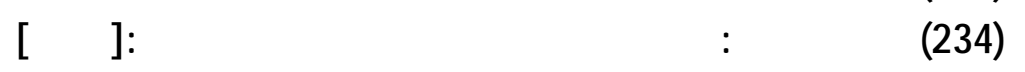

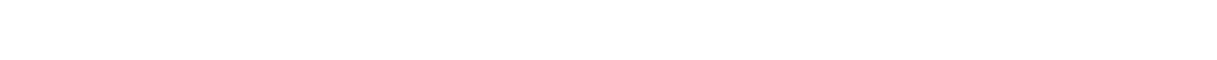

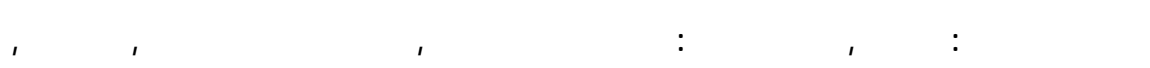

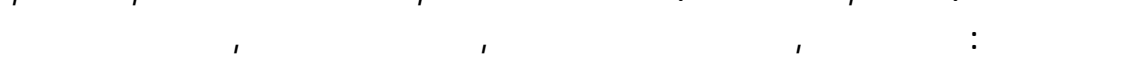

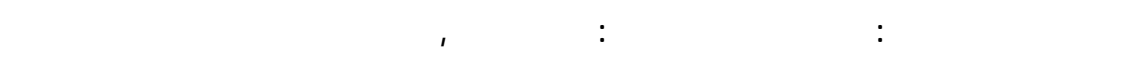

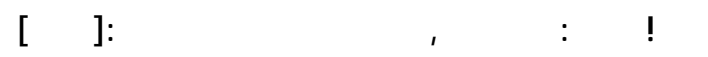

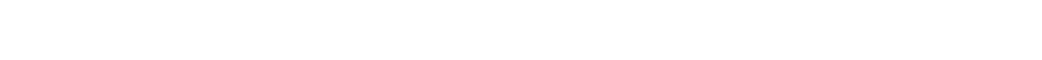

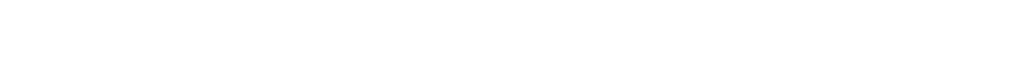

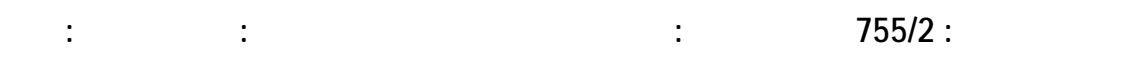

مجلة بحوثكلية الآبل 
الإبلام في غسه , ولعله يعذر في ذلك لجهله , وعدم معرفته , وال أعلم.

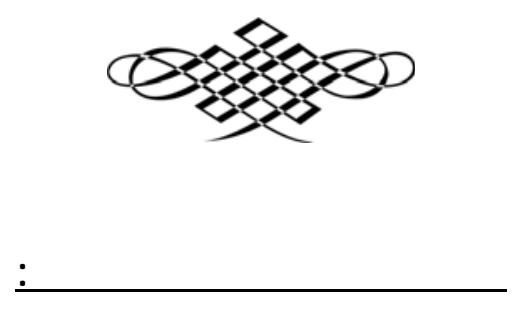

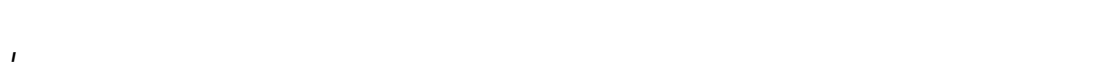

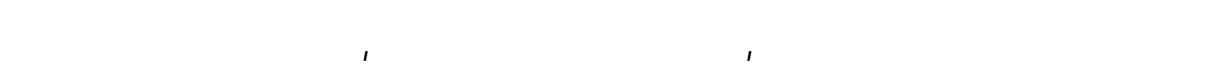

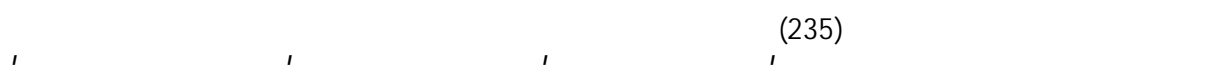
وعنايته بتقبح قصائه، و وتحبيرها , حتى قل إنه يظم القصية في تشعين بيتاً , فما

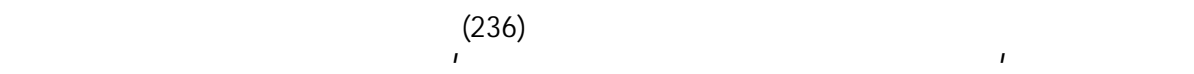

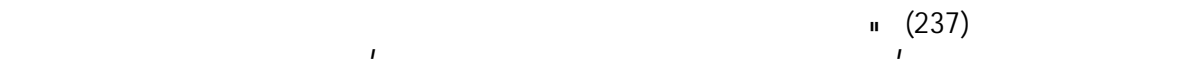

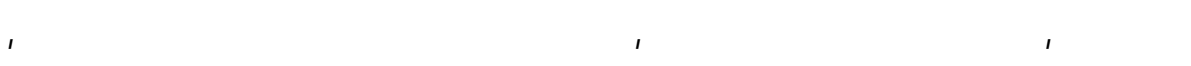

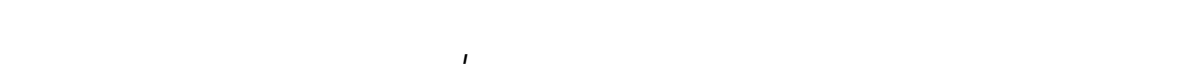
لمصلحتهما" (238)

وقد لمنفاد الأنطل منشعر النابغة للثيء الكثير , وإنه ليأخذك العجب ,

$$
\begin{aligned}
& \text { (235) اللمفهال، ألو لهرج: 295/8، و303/8. }
\end{aligned}
$$

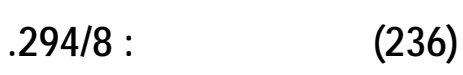

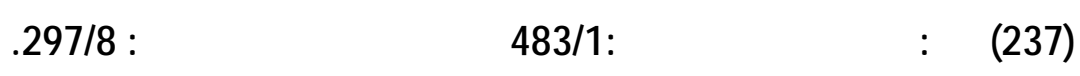

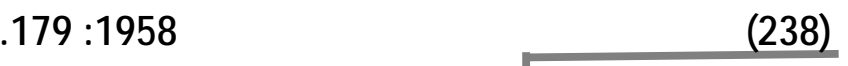


د ار راشد بن مبارك الرشود

وأنت تقرأقصيدته الرائية في مدح يزيد بن معاوية :[البسط] (239)

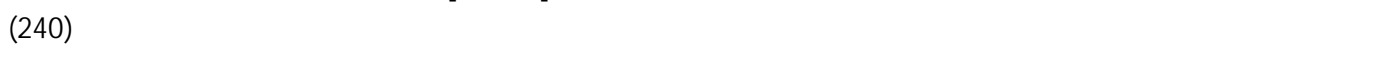

من تشابهها مع رائية النابغة الذبياني التي مطلعها: [البسط] (241)

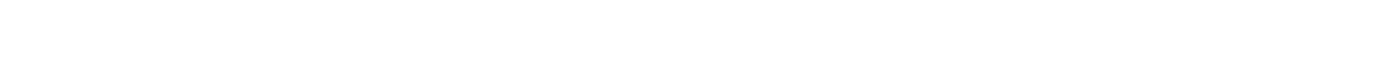

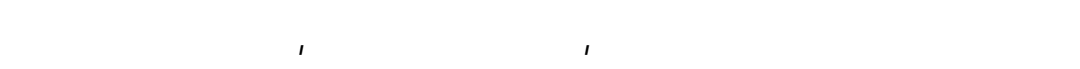

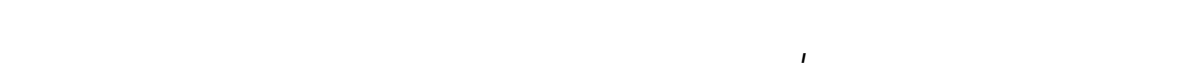

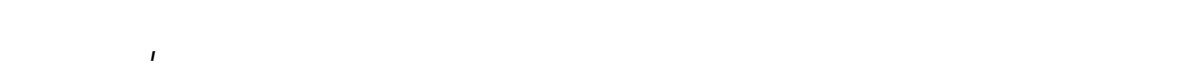

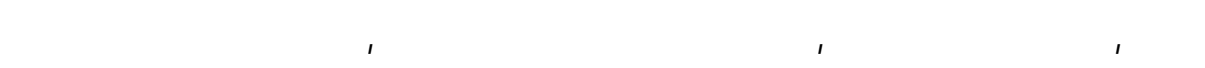

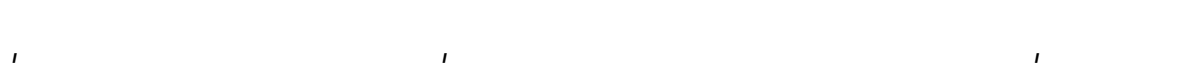

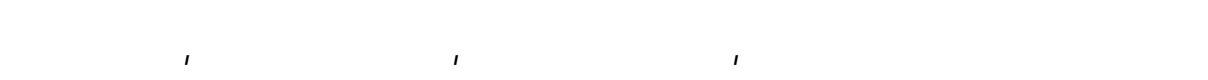

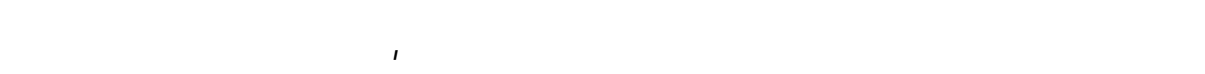

من نصررانيته على هلمش الحية الاجتماعية في عصره .

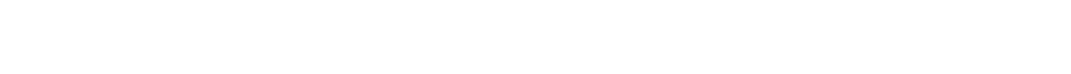

$$
\text { يسطبع أن يقسمها إلى قسمن : }
$$

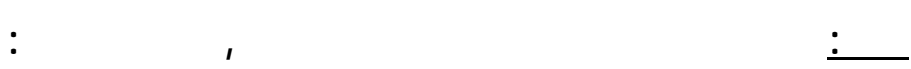

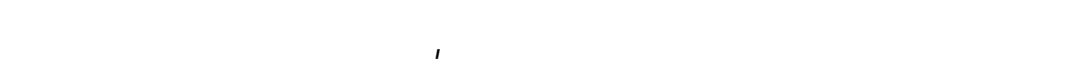

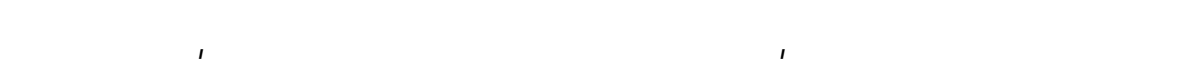

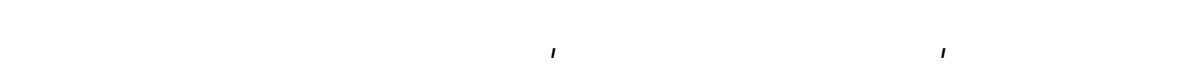

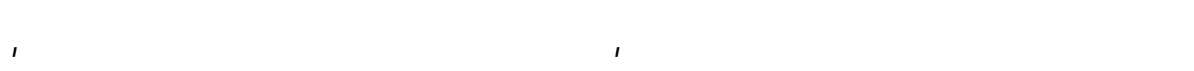

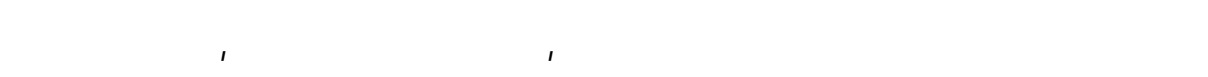

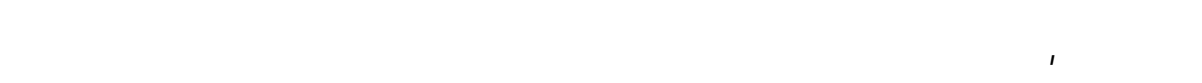

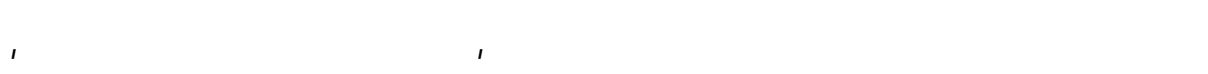

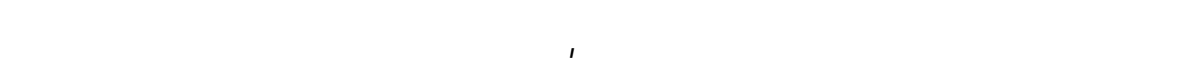

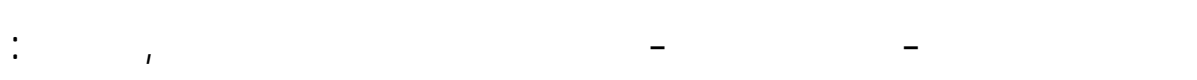

(239) دوانه: 161/1.

(240) المسم: ما تق من الأثر، وألفار: لمه موضع، وأنفرت: خلت، المهة: النجاة السودأ

والرماد،

(241) الذياله، النبة، ديوله: 202.

مجلة بحوث كلية الآدلب 


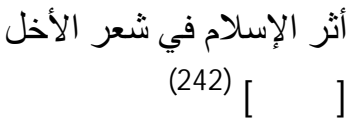

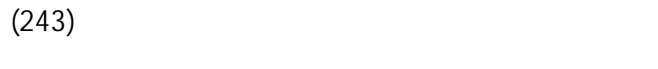

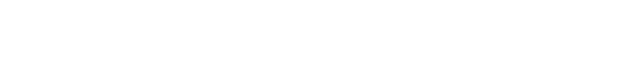

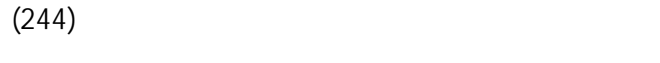
15

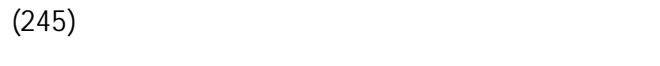

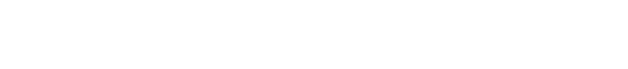
ويقول أيضاً:[الطويل]

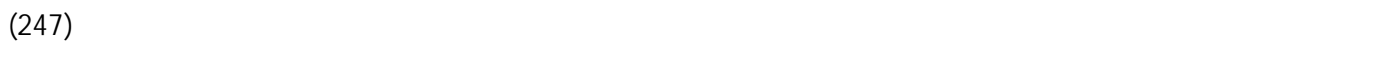

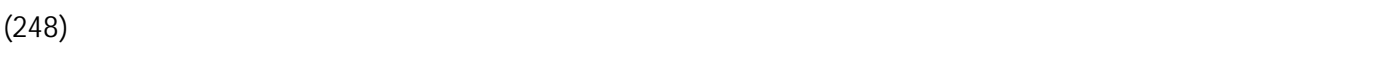

في مشهد في لخر اعتادشعراء العرب على تصويره في ق صصائده ، فاطيور تغدو خماصاً , لكسب قوتها , ولسد جوعها في وقت مبكر من اليو , فهي

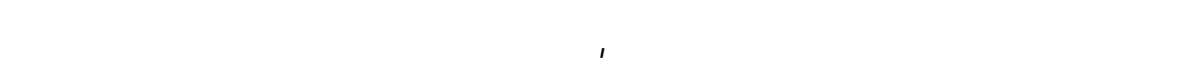

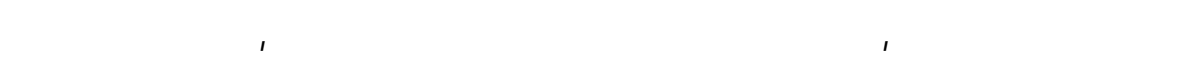
بالنجح والتيسير, يقول لمرؤ القيس: [الطويل] (249)

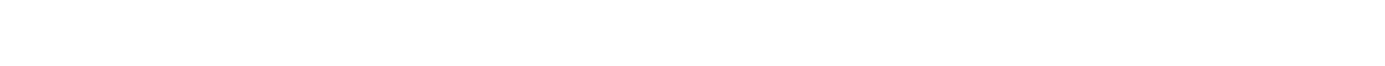

ولكن الأخطل يستمد من البيئة الإبلامية رمزَ لخر للبكور يجعله أق _رب إلى للسلمع , وألصق بذهنه من غدو الطيور ورولحها التي ربما تقد في بيئة مـ نـ البيئت , وتوجد بكثرة في غيرها , ولكن صلاة الفجر وأذانها أوضح مثل للبكور

(242) ديواd: 154/1) 1552)

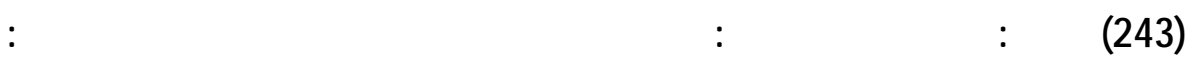

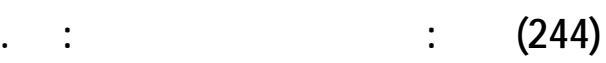

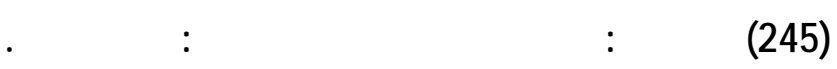

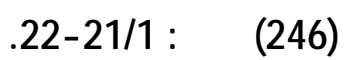

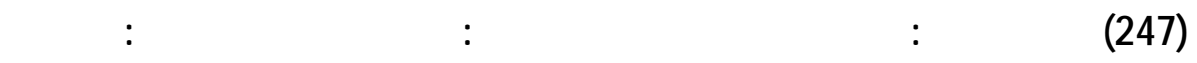

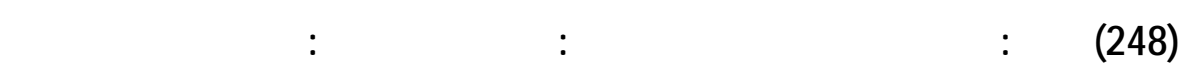
اليمن، ومكل:هقيد. 245/1 (249) لهؤ لفيس، ديولة 
دا راثد بن مبارك الرشود

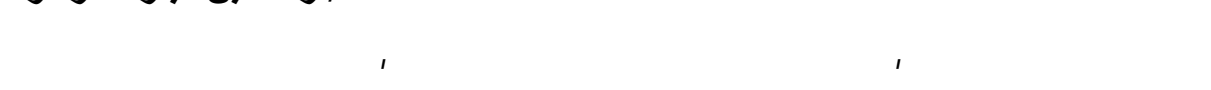
هجوم قومه على أعدائهر ذلكراً هذا الرمز:[الخفيف] (250)

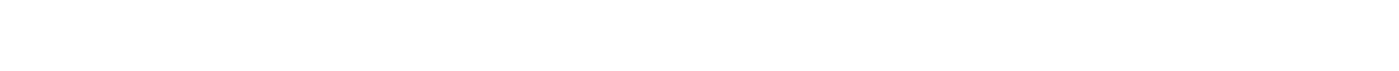

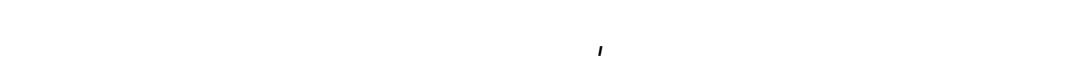

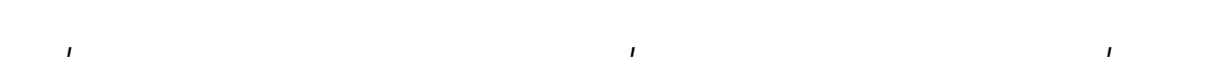

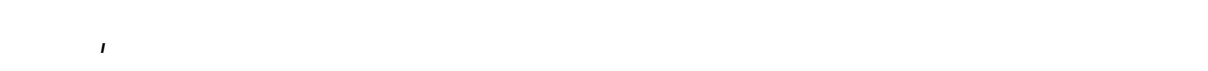

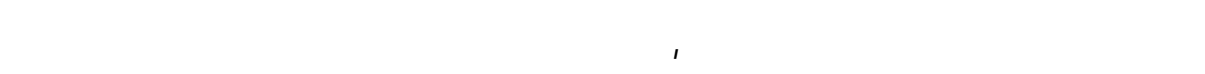

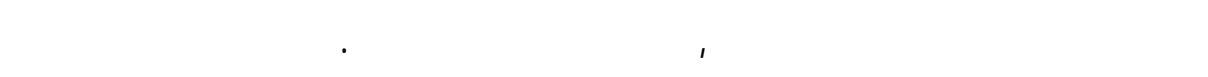

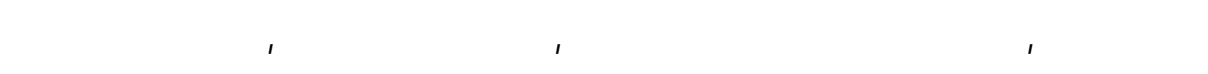

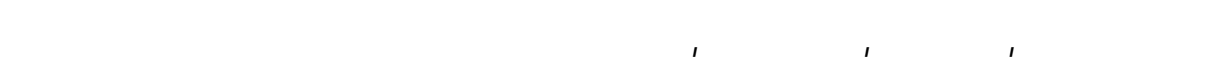

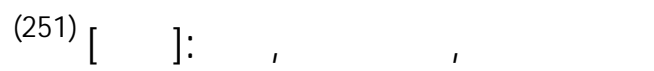

(252) 29-29日-

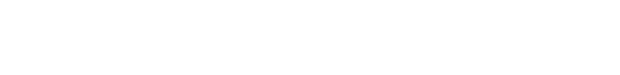

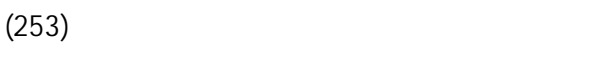
(254)

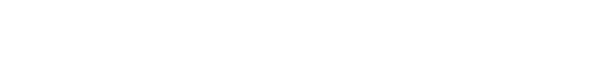

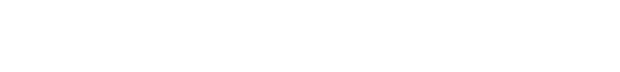

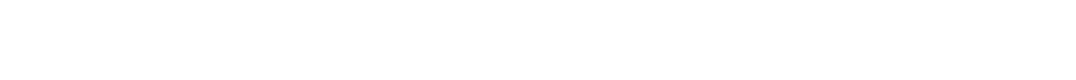

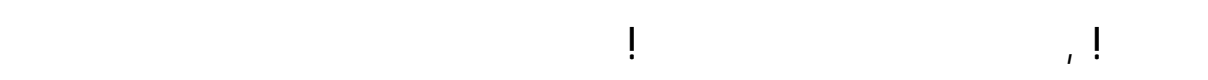

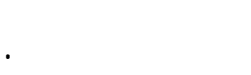

يروى أن يزيد بن معاوية خرج بالأخطل معه إلى الحج(255). وقد تؤي 2.

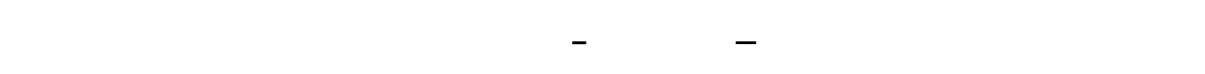

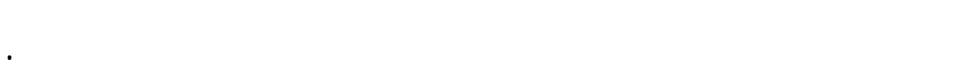

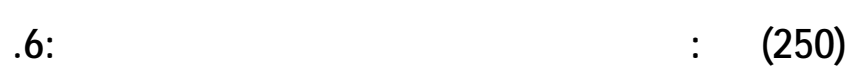
(251) نيوله: 258/1.

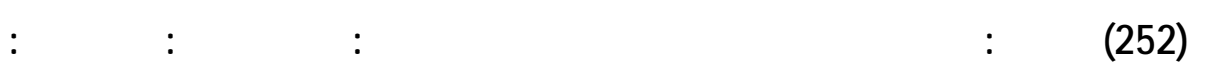
الزرب.

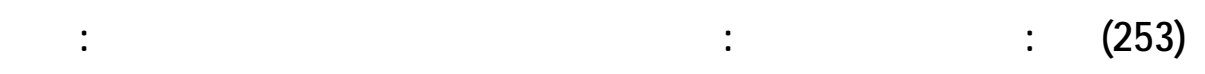
وبهدأفلا يتحرك.

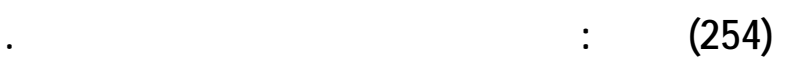

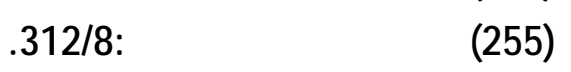




\section{ثلنياً : صورة تهتمد على المعرفة والمله، ومن أمثلتها:}

الفة الجاهلية مصطلح لإسلامي نكر في القرآن وللسنة كما ق ال تع اله اله:

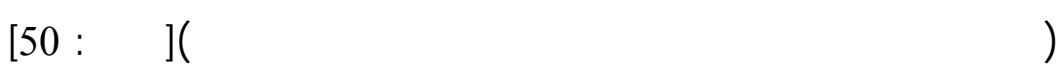

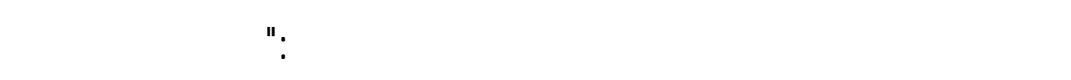

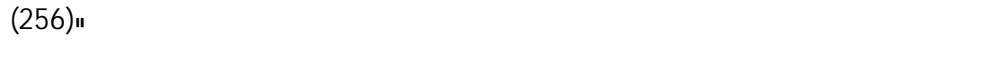

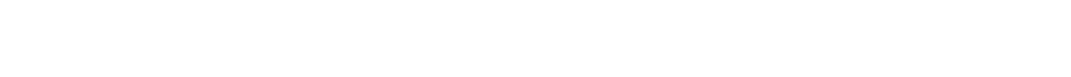

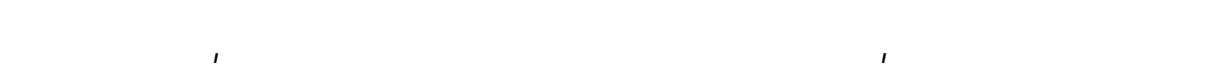

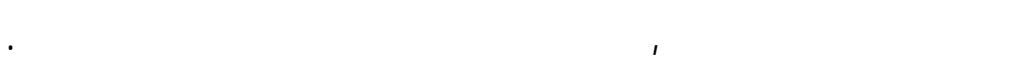

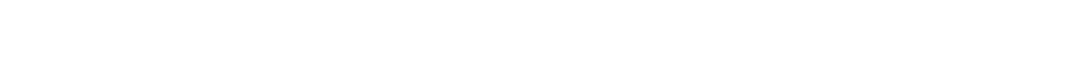

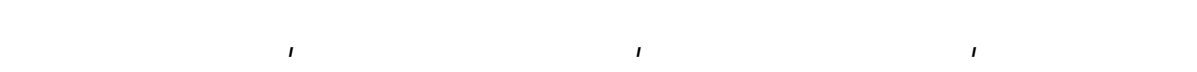

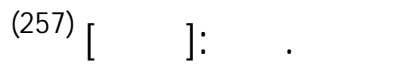

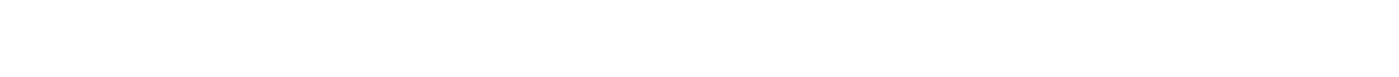

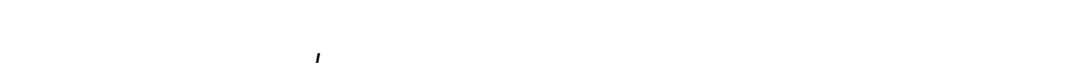

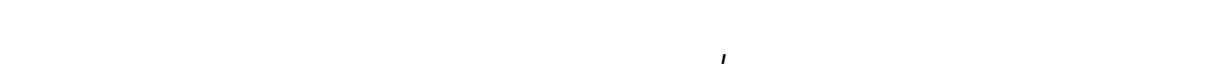

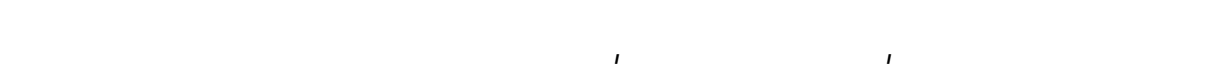

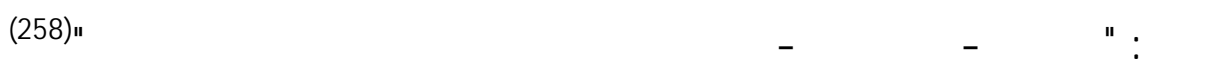

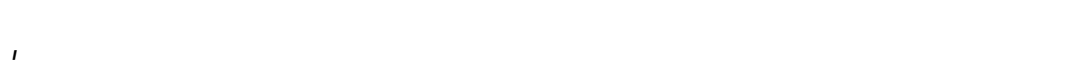

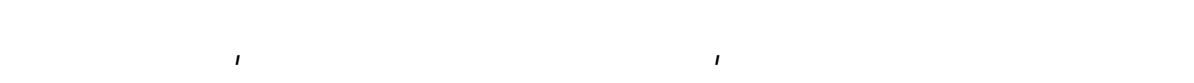

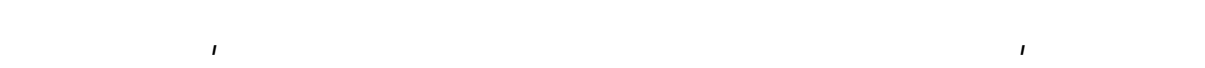

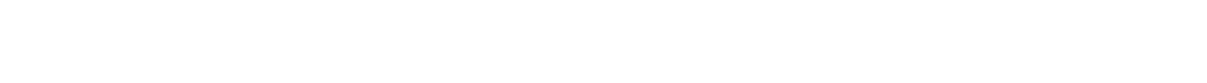

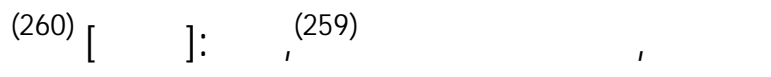

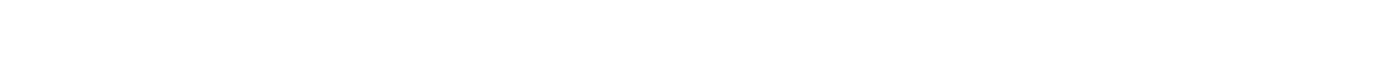

(256) البخالي:صجح: 2588/6،حيث قر 6644.

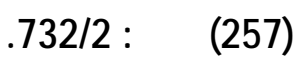

(258) النلوي، إبليا، الأغل: 25.

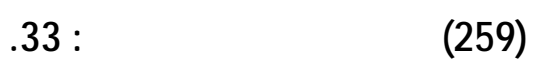

187/1:

مجلة بحوث كلية الآلب 
د/ راثد بن مبارك الرشود

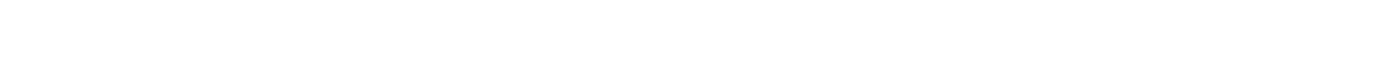

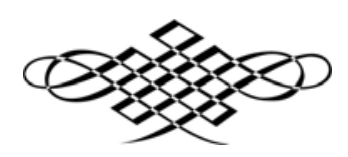

\section{الخاتمة}

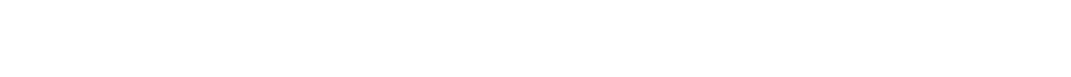

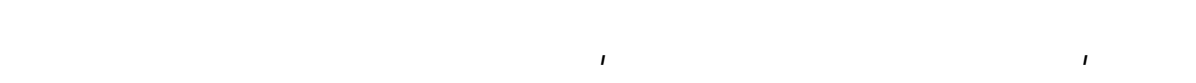
هذه الدرلسة:

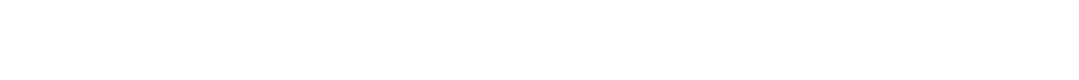

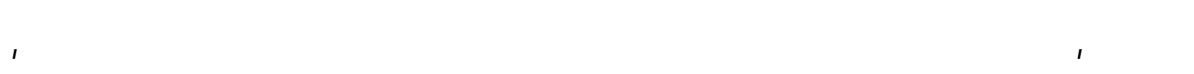

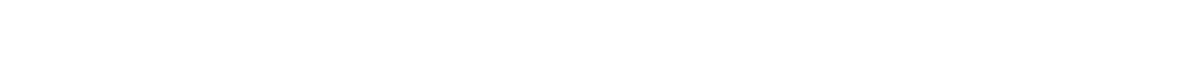

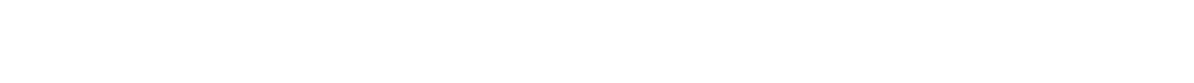

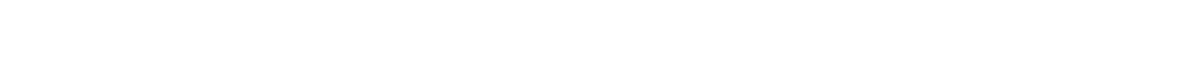
الآخرين, وكشرب الخمر وتميزه في هذه الصفة، وكاللهو والمجون, ثم ترلجعه بعد المبند ذالك عن صبواته. فم بينا أثر نصرليته فيشعره, ونكرنا أسببلب ندرة هذا الأثر كعدم اقتناعه

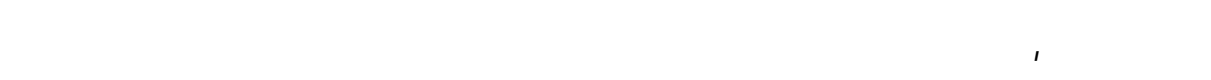

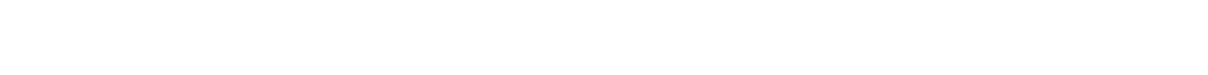

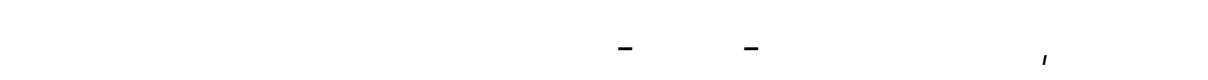
الرئيس في ذلك هو خوفه من جرير الذي كان يعيره بنصرالنيته, فلو أسلم لكان في

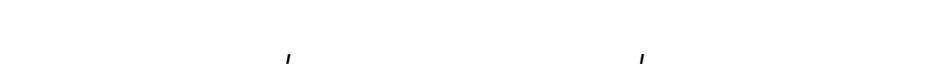

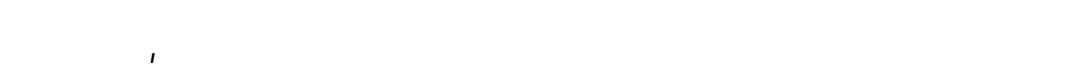

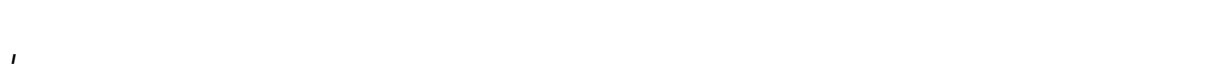

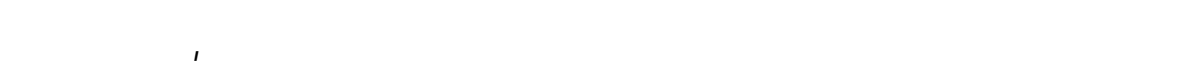

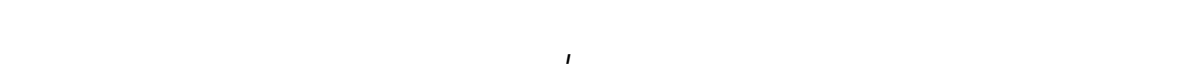
بمفهومه الإسلامي حين قل: [البسط]

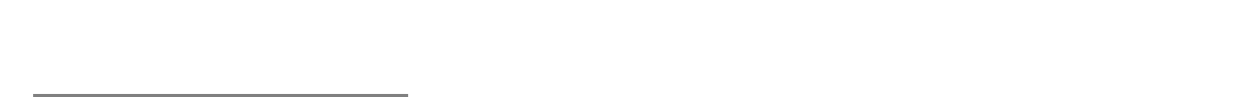
مجلة بحوثكلية الآلب 


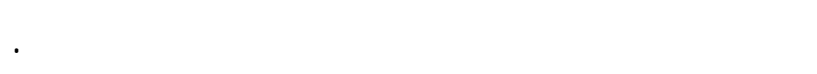

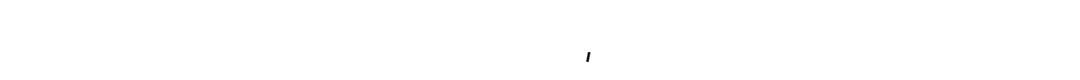
الرسول صلى الم عليه وسلم حن قل يهجو بني أسد: [الطويل]

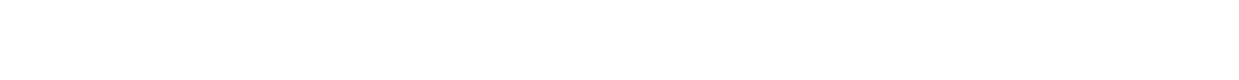
وأما الكتب المقهة , فلم ينكر منا إلا القرآن الكريم , ومع ذلك فيلن تأثره به بدا واضحاَ فيشعره, وقد نكرنا لمثلة ذالك.

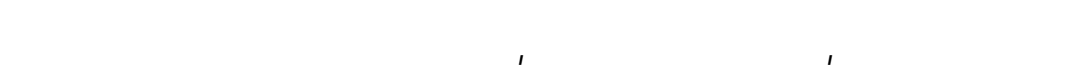

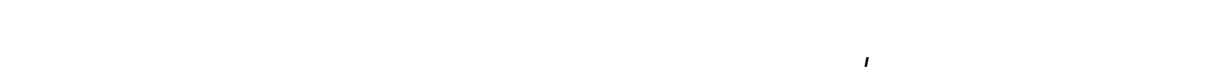
الجنة, وذلك في قوله: [البسط]

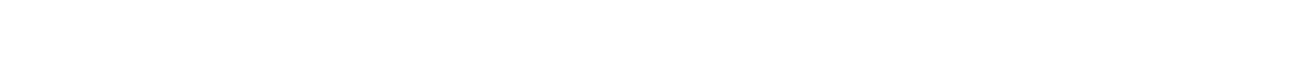

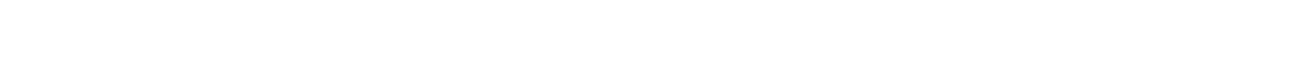

ولستعرضنا في المبحث الثالث مفهوم الأخطل للحكم, وتبين لي أنه ت أثأثر

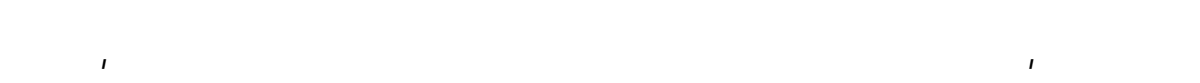

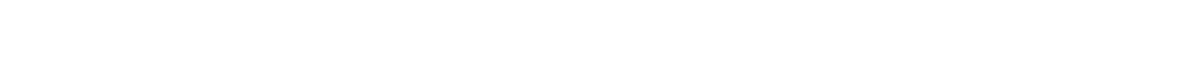

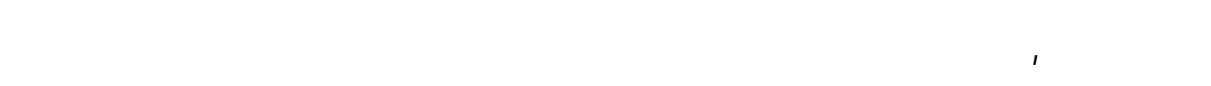

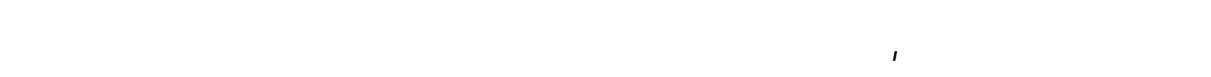

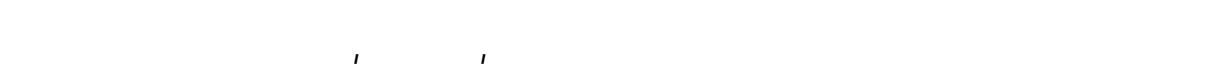

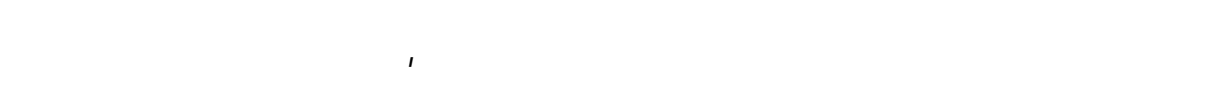

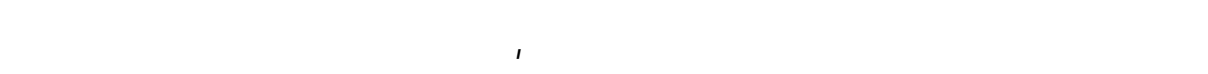

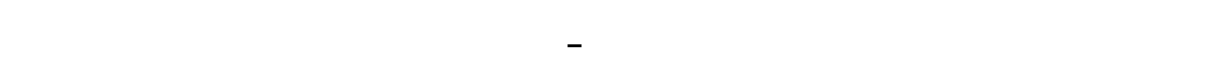

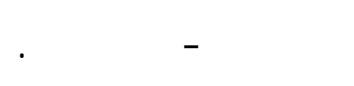

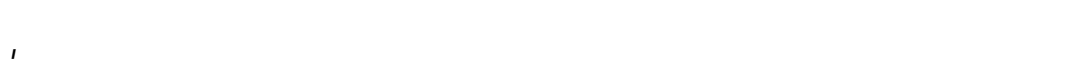
ويأتي على رلمسها الصلاة والحج؛ لأنهما ركنان من أركان الإسلام؛ ولأنهما مـ ن

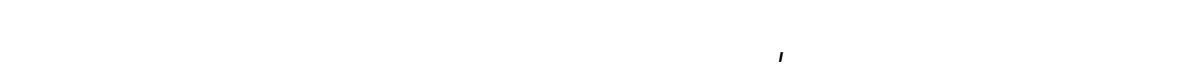

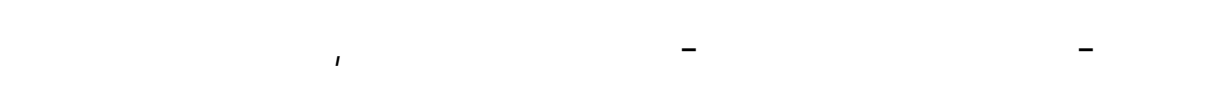
أبياته التي أولها: [الوافر] 
دا راشد بن مبارك الرشود

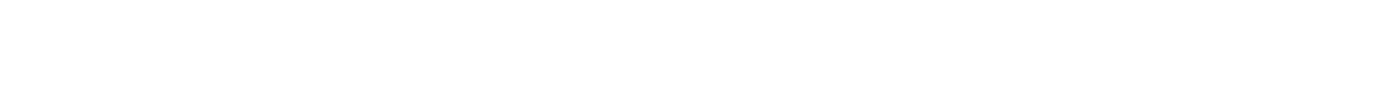

ووضعنا أملمها عدة افتراضلت, ملت خلالها إلى ترجبح أنها منسوبة إليه,

مكذوبة عليه.

وتناول المبحث الخلمس أثر الإبلام في تصويره الفني, فقد لستمد الأخطل

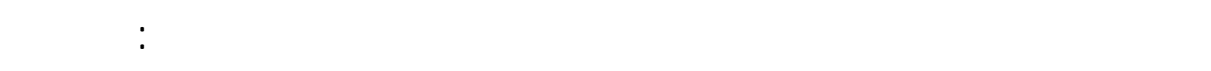

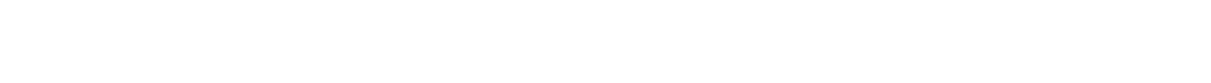

تعتمد على العلم والمعرفة.

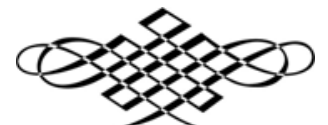 \\ قأمة المصادر والمرلج}

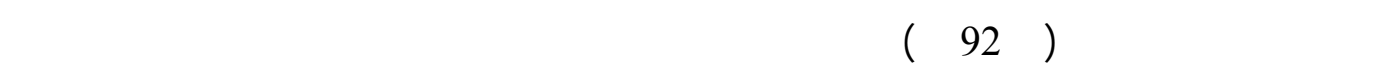

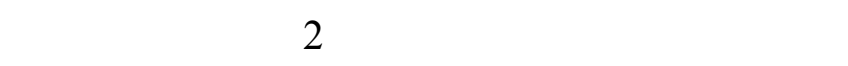
الجديية، 1399هـ _/979 ام. فخر فئ

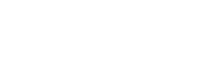
الغلالب

لأغلي، تحقيق علي مهنا وسمير ج ابر، لبذ ان، دار الفك ـر للطباعة والنثر، د.ت.

الأمفهالي، ألبو (ت 365هـ - ) الفرج علي بن البون الهسين

ديولن امرئ النيس ومالفالتهبشرح أب ميس عيد الـ سسكري

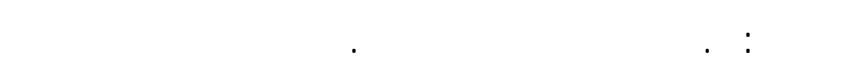
المؤ الفيس،

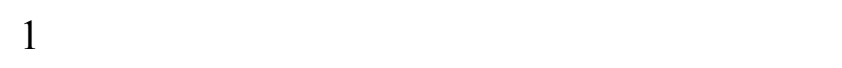
الكني المؤي

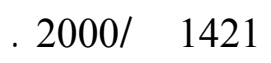

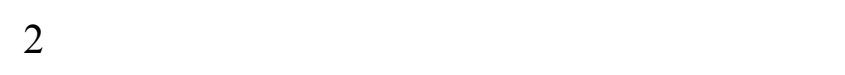

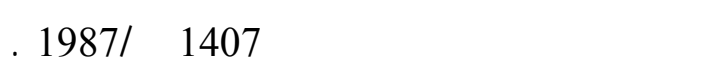

البخاري، أبو عبد (ت 256 هـ ـ )

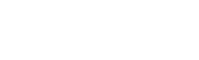
إلسماعل الجمفي

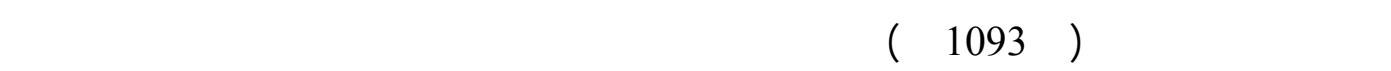

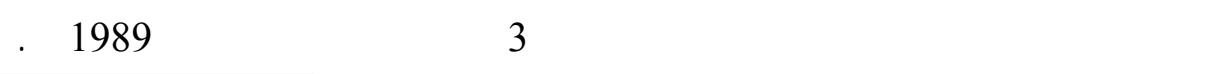
مجلة بحوث كلية الآلب 54 


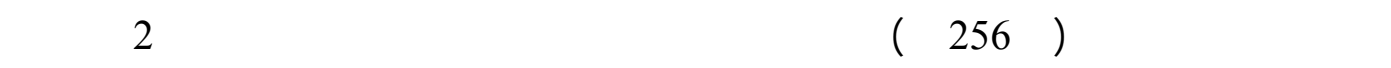

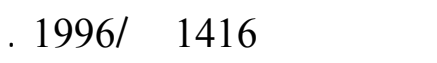

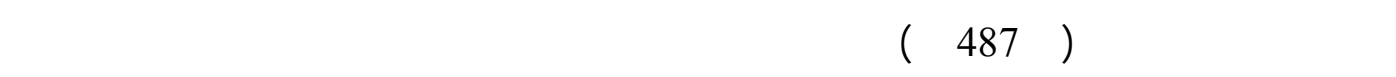

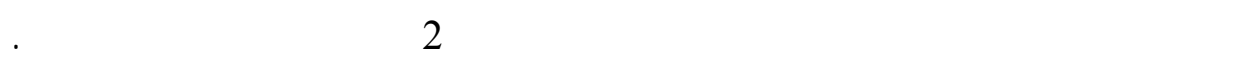

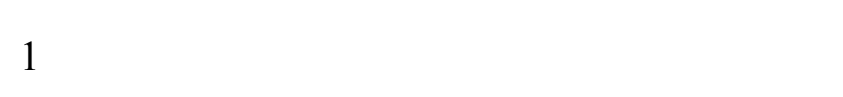

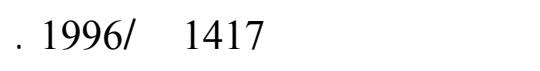

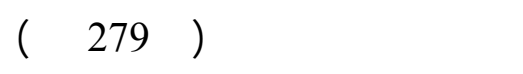

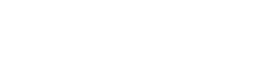
دلود

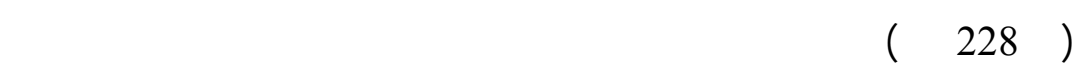

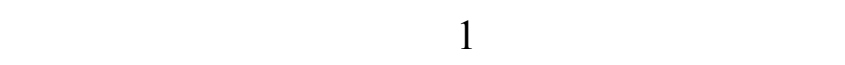
لبو تملم، حبيب بن ألوس اللائي للأباء اليسوعين، مالح اليسوب، 922 م.

العبوية,ط 5 , المكتب الإسلامي , بيروت , 1399هـ -.

الحيول، تحقيق عبد اللسلام محمد هارون، لبنلن، دار الجي لـ،

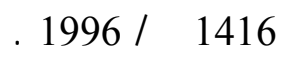

البن تيمية، قي (ت 728هـ - ) البن ألمد

(ت 255 هـ

الجلطا، ألبو عثمل عمرون البون

بحر

ليوله، بشرح محمد بن حبيب، تحقيق الكتور نعملن محم ــ

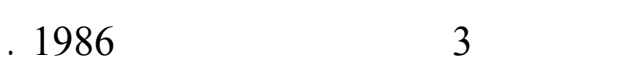

(133 (133)

جريربن علية، لبوحرزة التميسي

(ت 231هـ -) طلقل فحط الشعراء، تققيق محمود محمدشلكر، جة، دار الجمهي، محمد بن

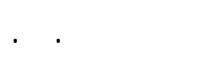
سملم الأخل،ط 1، بيروت، دار القالة، 1399هـ ـ الحاوي، إيليا - اليا (ت 1402هـ ) الهجاء والهجاعهن في صدر الإبلام، ط1، بيروت، دار

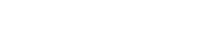
النهضة العربية، 1391هـ -. lan

صصحيحه، تحقيق محمد فؤاد عبد الباقي 1 1، بيروت، دار إحياء لبو الهسبن، مسلم

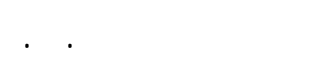
بن المجاج 
د/ راشد بن مبارك الرشود

ديولنه، تحقيق محمد أبو الفضل إبراهيم،ط2، الق اهرة، دار

$$
\text { المعارف، } 1985 \text { م. }
$$

العمدة في محلسن الشعر وآدلبه وقنه، تحقيق محيي ال ـين عبد الحميد، بيروت، دار الجيل، 1401هـ ـ/1981م.

$$
\text { الهشه، لبنان، دار الفكر، 1399هـ _/979م. }
$$

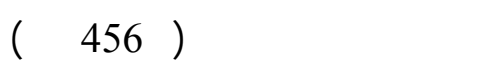

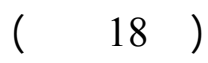
زالنبيلن، النبغة، الفالفي النثيسري

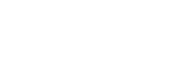
الأزي المن المن

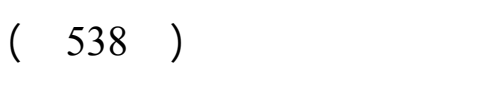

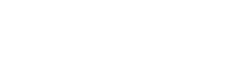

الأنسل، تحقيق: عبد الم عمر البارودي،ط1، بيروت، دار الفكر، 1998م.

(ت 562 ه

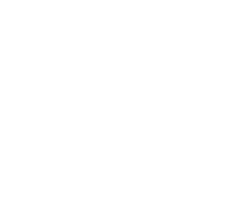

الأخل شاعر بفي أمية , ط 4 , دار المعارف مصر ,

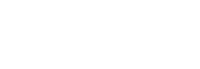
. - 1399 المر المنثورفي الفسير بالمألور، 1، بيروت، دار الفك ـر،

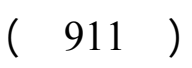
السيولي، ألبو بكر عبد
الرحمن

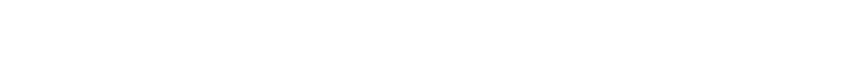

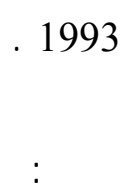
. 1985

المسيحية،6، القاهرة، مكتبة النهضة المصرية، 1398هـ -ـ شالبي، أحمد

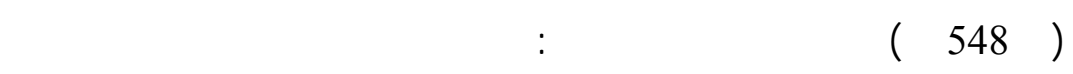
اللثهوسنالي ط3، لبنان، دار المعرفة، 1993 19/1414هـ ـ ـ . 


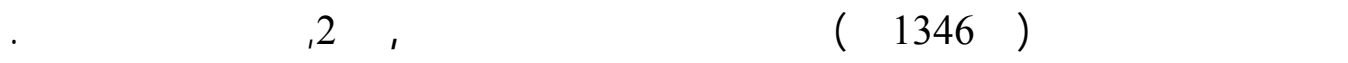

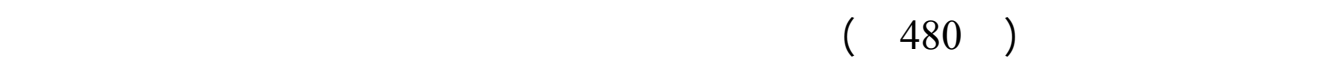

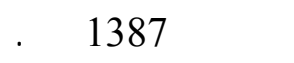

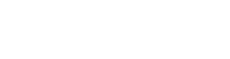

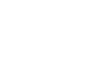

الشذر الذهبي فيشعر لأذل النغلب،ط 1، بيروت، الطبعة صالحالي، ألفلولن

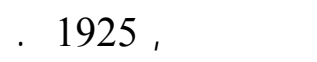

الوائ بالوفيل، تحقيق لحمد الأرناؤو، وتركي م صطفى، بيروت، دار إحياء التراث، 1420هـ ـ/ ـ2000م.

(ت (ت)

المفي، صد الاح

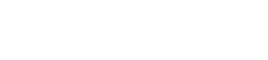

العصر الإسلاي،ط10، القاهرة، دار المعارف، 982 م. (ت 1426هـ (ت)

(ت 963 هـ ـ) معالهد التنصيص، تحقيق:محمد محيي الين عبد الحميد،ط1،

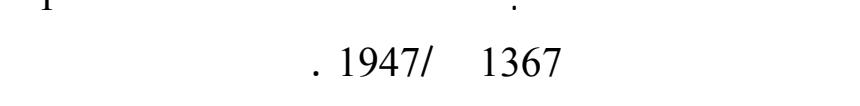

ضفيفوقي العبلمي، عبد

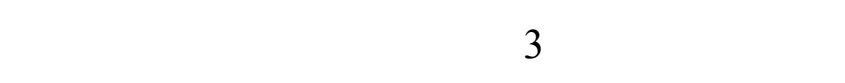
(ت 328هـ (-)

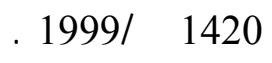

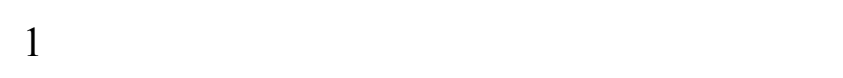
بيروت، دار الجل، 1412هـ ـ/992 الئه. العقلاني، ألبو (ت 852 هـ ـ)

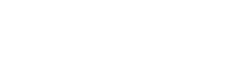
عالي الن حجر

المحرر الوجيزفي فسير الكتب الهزب زب، تحقيق: عبد للسلام

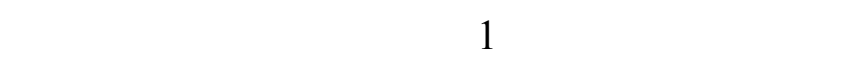

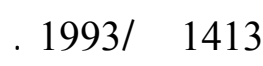

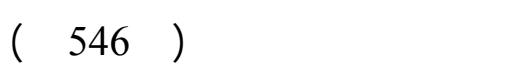
محمد عبد الهق عابه.

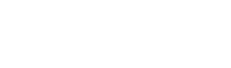

الفطل في تاريخ العرب قل الإسله، ط 1, دار العلم علي، جواد

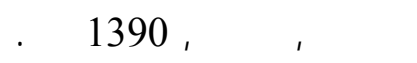
الأخل الكبير، 2, بيروت، منشورات دار الآفق, 1399هـ ـ قباوة، فخر الين 


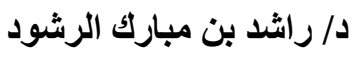

اللثعر واللثعراء، تهقيق أحمد محمدشلكر،ط2، مصر، دار

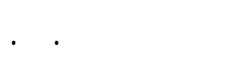

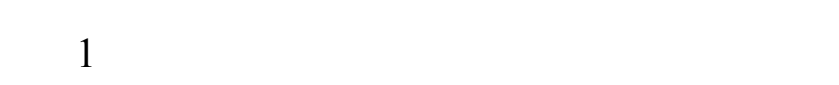

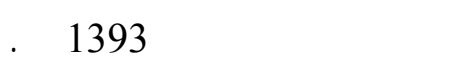

الأخل، مجلة المجمع العلمي العربي بنشق، 958 ام. البن قتيبة، ألبو (ت 276 هـ - ) محمد عبد البن البون

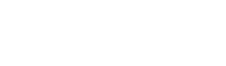

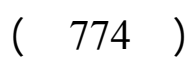
البن كثير، ألبو الفداء إلبماعل ليول

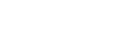

مرم، خخلل الموشح، تققيق محمد علي البجاوي،ط 1، القاهرة، دار نهضة

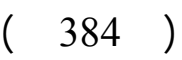

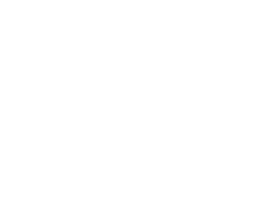

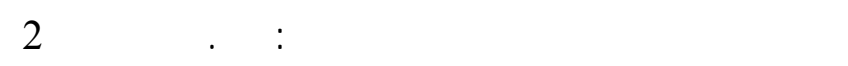
بيروت، دار الكتب العلمية، 1402هـ _/982م.

منحة الفربب المجيبف الرد عل عبلد الصليب ,ط 3, دار قفف, الرياض , 1400هـ ـ .

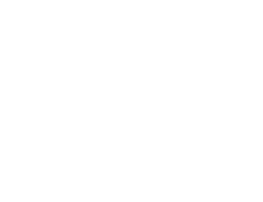

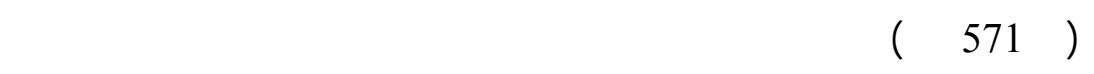

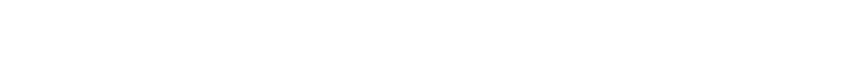

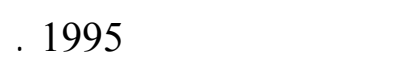

(ت 1417هـ -) لجاهات اللثعر العري في الفرن الثلي الهجري، ط1،

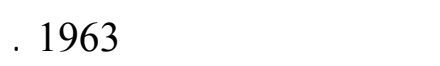

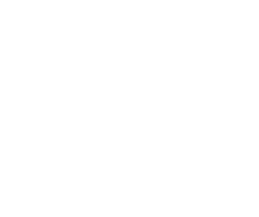

هدارة، محد2 مصeف :

J. S. M eisami and P. Starkey,Eds., Encyclopedia of

A rabic Literature, London and N ew Y ork, R outledge, 1998. 
أثر الإسلام في شعر الأخل

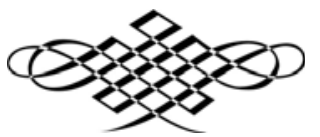


د/ راشد بن مبارك الرشود 
أثر الإسلام في شعر الأخل 